\title{
Exploring Space, Economy, and Interregional Interaction at a Second-Millennium B.C.E. Citadel in Central Western Anatolia: 2014-2017 Research at Kaymakçı
}

\author{
CHRISTOPHER H. ROOSEVELT, CHRISTINA LUKE, \\ SINAN ÜNLÜSOY, CANAN ÇAKIRLAR, JOHN M. \\ MARSTON, CAITLIN R. O'GRADY, PETER PAVÚK, \\ MAGDA PIENIĄŻEK, JANA MOKRIŠOVÁ, CATHERINE B. \\ SCOTT, NAMI SHIN, AND FRANCESCA G. SLIM
}

Open Access on AJA Online

Includes Supplementary Content on AJA Online

Current understandings of the archaeology of second-millennium B.C.E. central western Anatolia are enriched by ongoing research at Kaymakçı, located in the Marmara Lake basin of the middle Gediz River valley in western Turkey. Discovered during regional survey in 2001, the site offers a critical node of exploration for understanding a previously unexamined period in a well-traversed geography thought to be the core of the Late Bronze Age Seha River Land known from Hittite texts. Here we present results from the first three seasons of excavation on the citadel of Kaymakçı plus a study season (20142017), introducing the site's chronology, historical and regional context, and significance through presentation of excavation areas as well as material and subsistence economies. With reference to such evidence, we discuss the site's development, organization, and interregional interactions, demonstrating its place in local and regional networks that connected Aegean and central Anatolian spheres of interest. ${ }^{1}$

American Journal of Archaeology

Volume 122, Number 4

October 2018

Pages 645-88

DOI: 10.3764 /aja.122.4.0645

www.ajaonline.org

\footnotetext{
${ }^{1}$ For research permissions and assistance, we gratefully acknowledge the General Directorate of Cultural Heritage and Museums of Turkey's Ministry of Culture and Tourism and its annual representatives Ö. Çavga, S. Yılmaz, L. Pancar, and N. Okan, as well as the Manisa Museum of Archaeology and Ethnography, its current and former directors H. Güllü and S. Soyaker, and their staff. This research could not have been conducted without essential funding from the National Endowment for the Humanities (Award RZ5155613), National Science Foundation (Award BCS-1261363), Institute for Aegean Prehistory, Loeb Classical Library Foundation, Merops Foundation, Boston University Vecchiotti Archaeology Fund, Koç University, Czech Science Foundation GAČR (Award 17-19746S), European Regional Development Fund (No. CZ.02.1.01/0.0/0.0/16_019/0000734), and many private donors. We express our sincere gratitude for their confidence and support. For helping manage our teams with familial grace, humor, and calming aura, we thank D. Şener, M. Şener, A. Kerse, and A. Yıldırım and are grateful to our dedicated staff from the villages of Tekelioğlu, Hacıveliler, and Büyükbelen. Thanks are due also to J. Kelder and the anonymous reviewers of previous versions of this manuscript. Additional figures can be found under this article's abstract on AJA Online (www.ajaonline.org).
} 


\section{INTRODUCTION}

The Kaymakçı Archaeological Project (KAP) was established in 2013 to conduct excavations and related activities at Kaymakçı, a second-millennium B.C.E. site located in the Marmara Lake basin of the Gediz River valley, province of Manisa, western Turkey. ${ }^{2}$ Building on the preliminary results of the diachronic Central Lydia Archaeological Survey (CLAS, 2005-2014), ${ }^{3}$ excavations at Kaymakç began in 2014 with the aim of exploring the development, spatial organization, and economies of the site. With four seasons of research now complete including the 2017 season, ${ }^{4}$ this article focuses on the implications of results from excavations and material analyses for understanding activities and interactions across the site, the region, and the broader Aegean and Anatolian worlds during the second millennium B.C.E. Excavations at Kaymakçı are planned to continue at least six more years, according to the 10-year research program submitted to the Turkish Ministry of Culture and Tourism. Final publication of excavation sectors and finds will follow, while separate articles will treat specific sets of data.

\section{REGIONAL SETTING AND PREVIOUS RESEARCH}

Kaymakçı is situated above and along the western shore of Lake Marmara, an approximately $50 \mathrm{~km}^{2}$ inland lake located along the northern margin of the Gediz (classical Hermus) River valley, about $100 \mathrm{~km}$

\footnotetext{
${ }^{2}$ We thank P.J. Cobb, T. Kaner, and E. Moss for their essential implementation and management of the recording system in the 2014-2016 field seasons. We give thanks also to all project participants between 2014 and 2017, including K. Adams, E. Adeyemo, D. Alberghina, H.R. Aslan, A. Aydın, E. Ayten, R. Bennett, M. Blumer, N. Büyükyüksel, C. Calorusso, H. Chasteene, T. Clements, M. Çoban, A. Crowe, P. Demján, A. DiBattista, E. Dinçerler, K. Egerer, G. Eren, E. Erlat, K. Ernst, K. Forste, F. Franković, T. Frank, N. Gail, N. Gauthier, A. Gendron, K. Gillette, A. Graham, B.İ. Güzel, H. Hatay, S. Hepkabral, K. Jarošová, E. Johnson, B. Katen, M. Kim, E. Kiras, R. Kneski, E. Konakçı, J. Kooistra, M. Külekçioğlu, D. Langis-Barsetti, K. Leloux, M. Lill, C. Martin, M. McDonough, C. Mead, C. Mikeska, G. Nobles, B. Olson, G. Özçolak, E. Özgüroğlu, N. Özköylü, H.B. Özmen, F.E. Özsoy, N. Passerotti, D. Plekhov, E. Prideaux, J. Puskás, M. Roháček, N. Sanjaya, S. Schweri, B. Sekedat, E. Sezgin, J. Shaw, L. Šušková, N. Susmann, C. Tomkin, R. Van der Putte, E. Wilson, B. Yilmaz, and N. Yilmaz.

${ }^{3}$ Preliminary results have been published in Araştırma Sonuçları Toplantısı. For full references, see Luke and Roosevelt 2017; Roosevelt and Luke 2017.

${ }^{4}$ Preliminary results have been published in Kazı Sonuçları Toplantısi, issues 37, $38(2016,2017)$.
}

east of the Aegean coast at Izmir in western Turkey (fig. 1). The archaeology of the lake basin has been known best as the immediate hinterland of Sardis, the capital of ancient Lydia, which is located about $10 \mathrm{~km}$ to the south across the Gediz Valley on the northern foothills of the Bozdağ (classical Tmolus) Mountain range. The lake was called the Gygaean Lake and Lake Koloë in classical times and, like the Iron Age burial mound cemetery that defines its southern shorecalled Bin Tepe, or "Thousand Mounds," in Turkish-it had sacred and ancestral associations relating to memories of the pre-Iron Age communities of the basin. $^{5}$

With its most conspicuous remains situated atop a ridge of bedrock, roughly $140 \mathrm{~m}$ above the level of the lake, Kaymakçı went unnoticed by archaeologists until 2001, ${ }^{6}$ after which time it was documented using noninvasive methods by CLAS. That regional project showed that Kaymakçı was only one of at least six citadels ringing the lake, five apparently unfortified lowland settlements, and at least 23 smaller sites of more ephemeral activities, all of second-millennium B.C.E. date (see fig. 1). ${ }^{7}$ Kaymakçı's fortified area of 8.6 ha is more than twice as large as any of its nearby peers, and its diverse internal spatial organization is evident from geophysical results and surface microtopography (online fig. 1). ${ }^{8}$ Additionally, dispersed remains of settlement and other functions, including a probable cemetery, extend well beyond the citadel.

\section{THE HISTORICAL SETTING AND CHRONOLOGY OF KAYMAKÇI}

The second-millennium B.C.E. history of central western Anatolia, an area defined here roughly as that between and including the valleys of the Bakurçay (classical Caicus) and Küçük Menderes (classical Cayster) Rivers, is one that begins and ends in almost complete obscurity. Throughout the period, the material culture of the inland area displays a strongly local, Anatolian character. The coastal strip also shows material with Aegean characteristics, if not actual imports, which, however, only occasionally reaches farther inland. ${ }^{9}$

\footnotetext{
${ }^{5}$ Luke and Roosevelt 2016.

${ }^{6}$ Roosevelt 2003.

${ }^{7}$ Luke and Roosevelt 2017; Roosevelt and Luke 2017.

${ }^{8}$ Full Araştırma Sonuçları Toplantısı references can be found in Luke and Roosevelt 2017; Roosevelt and Luke 2017.

${ }^{9}$ Mountjoy 1998; Niemeier 2005; Pavúk 2015; Girella and
} 


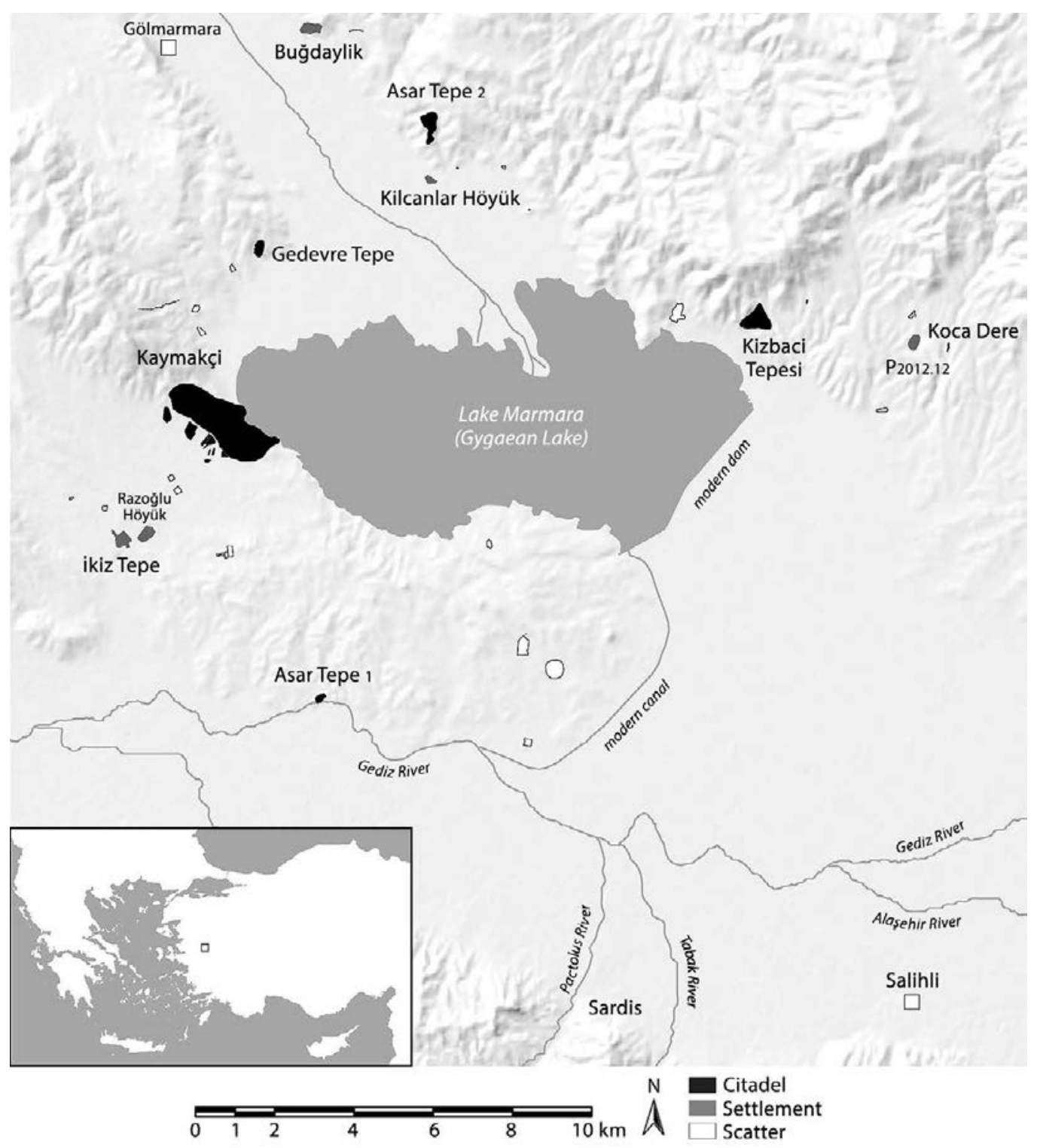

FIG. 1. Map showing the location of Kaymakçı and nearby sites in the Marmara Lake basin, western Turkey. Inset shows broader eastern Mediterranean setting (ㄷ Gygaia Projects).

Annals, treaties, letters, and other texts preserved on tablets recovered at Hattusa, the Hittite capital in central Anatolia, as well as at Amarna in Egypt, shed some light on political entities, events, and geographies, primarily of the 14th and 13th centuries B.C.E. These varied testimonies show that central western Anatolia held an important position in Hittite regional diplomacy and conquest. ${ }^{10}$ During this period, components of

Pavúk 2015, 2016; Mokrišová 2016.

${ }^{10}$ Hawkins 1998; Bryce 2005. the so-called Arzawa Lands interacted most frequently with members of an Aegean community known to the Hittites as Ahhiyawa, now most commonly thought to represent a Mycenaean group or their contemporaries in the eastern Aegean. ${ }^{11}$ On the basis that such interactions potentially threatened Hittite interests in the area, Hittite kings staked their claims both diplomatically and militarily. Treaties of vassalage bound local rulers closely to the Hittite king at times, while appar-

\footnotetext{
${ }^{11}$ Kelder 2009; Beckman et al. 2011; Bryce 2011.
} 
ent violations of the same, often involving Ahhiyawa, frequently raised the Hittite king's ire, resulting in campaigns of conquest or reconquest. It is in this secondmillennium B.C.E. historical setting that Kaymakçı was established, grew into the largest known site in the region, and was eventually abandoned. ${ }^{12}$

The second-millennium B.C.E. chronology of inland central western Anatolia has been an intractable problem since the 1950s and 1960s, when French first collected and published survey materials he was unable to date closely. ${ }^{13}$ Excavations to the north at Troy, ${ }^{14}$ to the east and south at Beycesultan and Aphrodisias, ${ }^{15}$ and to the west at Panaztepe and Limantepe, ${ }^{16}$ achieved refinements with stratigraphic control, yet without firm overall periodization.

Recent work at Troy and Beycesultan, ${ }^{17}$ as well as at newly excavated sites to the south, such as Bademgediği Tepe and Çine-Tepecik, ${ }^{18}$ and in the Izmir area ${ }^{19}$ allowed for further refinement, offering certain anchors for the working ceramic chronology at Kaymakçı: Kaymakçı was occupied already in the local Middle Bronze Age (MBA; ca. 2000-1700/1650 B.C.E.) and, more intensively, in the Late Bronze Age (LBA; ca. 1700/1650-1200 B.C.E.), followed perhaps by a final LBA or possibly an Early Iron Age (EIA) phase before it was abandoned. Analysis of local ceramics from the stratified excavations at Kaymakçı now suggests a further division of the LBA into at least two broad phases: ${ }^{20}$ an early phase (Late Bronze [LB] 1 ; ca. 17th-15th centuries) and a late phase (LB 2, ca. 14th-13th centuries). Thus three primary phases have been identified to date-MBA, LB 1, and

\footnotetext{
${ }^{12}$ For evidence of Hittite and Ahhiyawan interactions, see Hawkins 1998; Bryce 2005; Beckman et al. 2011.

${ }^{13}$ French 1969; see also Bayne 2000, 33, 79.

${ }^{14}$ E.g., Blegen et al. 1953; Korfmann 2006.

${ }^{15}$ Lloyd and Mellaart 1965; Joukowsky 1986; Mellaart and Murray 1995, 3:2, 21-2, 57.

${ }^{16}$ Günel 1999; Erkanal 2008.

${ }^{17}$ Dedeoğlu and Abay 2014; Pavúk 2014.

${ }^{18}$ Meriç 2003, 2007; Günel 2010; Meriç and Öz 2015.

${ }^{19}$ Aykurt 2010, 2013; Mangaloğlu-Votruba 2011, 2015.

20 There is currently no consensus on the periodization of second-millennium B.C.E. inland western Anatolia. The Kaymakçı Archaeological Project therefore uses Arabic numerals to designate local LB phases in order to distinguish between its newly understood local phases and previously attempted regional phasing for coastal western Anatolia (e.g., Aykurt 2013) and central Anatolia (e.g., Gunter 1991), both of which use Roman numerals and are not directly applicable to Kaymakçı. For further references, see Pavúk 2015.
}

LB 2-with a possibly later phase dating to the final LBA/EIA.

This history is now also supported by accelerator mass spectrometry (AMS) radiocarbon analyses of nine charcoal samples and five seeds. ${ }^{21}$ These data span the 20th to 15 th centuries B.C.E., corresponding to the MBA and LB 1 contexts that were sampled. The seed dates matched the expected ceramic dates well, even if the charcoal dates were sometimes a century or so older than expected. An absolute date for the LB 2 phase in the second half of the second millennium B.C.E. is now corroborated by the discovery of two fragments of Mycenaean Decorated Ware that indicate at least part of the LB 2 phase at Kaymakçı dates to the 14th-13th centuries B.C.E. (see below).

Accordingly, Kaymakçı was settled before and occupied throughout the period in which central western Anatolian communities feature in Hittite texts. No textual sources of any kind have been recovered from the site, yet most recent reconstructions of the political geography of the area consider the valleys of the Gediz and Bakırçay Rivers to be the most likely location of the Seha River Land, a component of the Arzawa Lands, and a Hittite vassal kingdom by the late 14th century B.C.E. ${ }^{22}$ Furthermore, the heartland of the middle Gediz River valley (i.e., the Marmara Lake basin and its network of second-millennium B.C.E. sites) has been suggested as a strong candidate for the core of the Seha River Land. ${ }^{23}$ At this time Kaymakç1 is the best candidate for its capital. ${ }^{24}$

\section{THE 2014-2016 EXCAVATIONS}

Excavation areas were selected to elucidate the nature of the broad spatial divisions of the citadel and, in part, to clarify microtopographic and geophysical survey results. Seven excavation areas have been opened to date (fig. 2). All excavation and material processing uses the KAP recording system, a digital workflow including volumetric (3D) modeling, photography, videography, textual documentation, and a relational database on a networked data server. ${ }^{25}$

\footnotetext{
${ }^{21}$ Publication of radiocarbon analyses conducted by Beta Analytic Inc. is in preparation.

${ }^{22}$ Hawkins 1998; Easton et al. 2002.

${ }^{23}$ Hawkins 1998, 24.

${ }^{24}$ Roosevelt and Luke 2017.

${ }^{25}$ See Roosevelt et al. 2015 for a full description of the KAP recording system and its approach to stratigraphic excavation and description.
} 


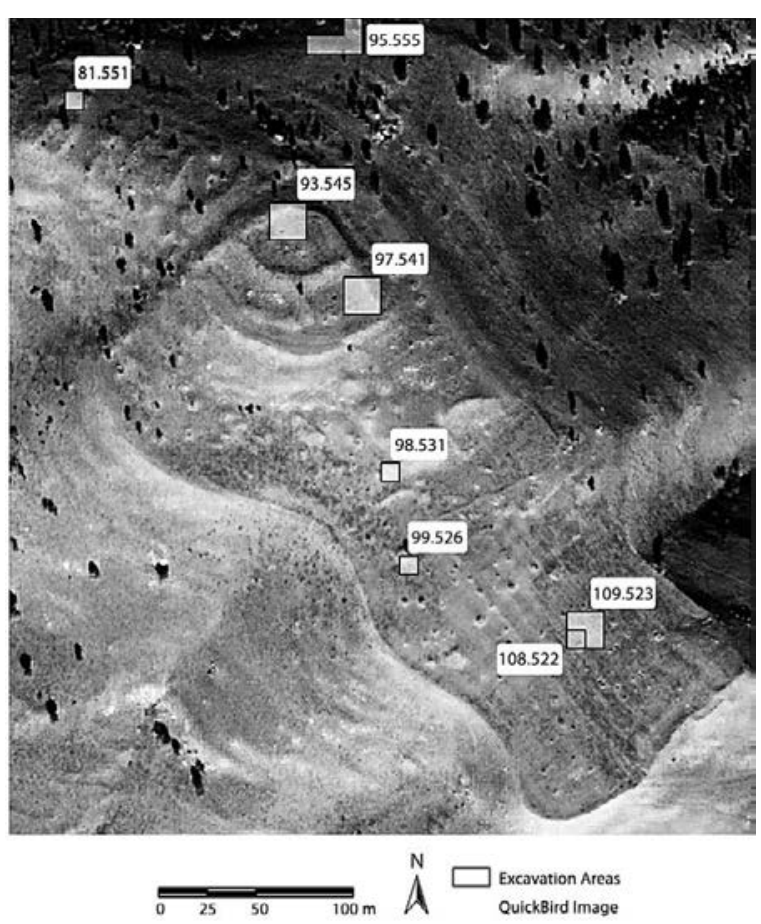

FIG. 2. QuickBird satellite image of Kaymakçı showing 20142016 excavation areas (ㄷ Gygaia Projects).

\section{The Fortification System}

A fortification system of diverse forms defines the citadel at Kaymakçı, enclosing approximately 8.6 ha of protected space (fig. 3 ). The system takes the form of a single curtain wall in the north (ca. $2 \mathrm{~m}$ wide in some places), and a double wall in the south, and is marked by projecting towers, bastions, and other features. Accesses through the fortifications via gates appear most likely at the southeast, southwest, and north.

Excavation area 81.551. The aim of excavations at this northwesternmost edge of the citadel, where geophysical survey results revealed what were interpreted to be several large and rectangular bastion-like structures, was to gain insights into the character and date of suggested fortification features. Excavation of a $9 x$ $9 \mathrm{~m}$ area in 2014 revealed two wide walls founded just above bedrock that formed an interior corner. The exposed walls clarify the geophysical results, showing that bastion-like features punctuated the northwestern fortifications by the LB 2 phase, at the latest.

Two distinct architectural phases were identified here: a substantial LBA phase and a less substantial later phase. The LBA phase is represented by two walls of the rectangular structure mentioned above that form an interior corner in the southwestern quar- ter of the excavation area (fig. 4). Wall 81.551.13 was preserved to a maximum height of approximately 1.8 $\mathrm{m}$ and extended $6.65 \mathrm{~m}$ from the southeast scarp toward the northwest, where it bonded with another wall, 81.551.14, which was preserved to a maximum height of about $1.5 \mathrm{~m}$ and extended perpendicularly at least $7.8 \mathrm{~m}$ toward the northeast. Both walls were about $2 \mathrm{~m}$ wide on average, though the base of wall 81.551 .14 widened to $2.45 \mathrm{~m}$ in places. Each wall was constructed using a face-wall or rubble-core technique. Relatively well-organized but unworked boulders and fieldstones were used to face a rubble core consisting of cobbles and boulders. While the foundations of wall 81.551.13 were relatively level, those of wall 81.551.14 stepped down to the northeast, following the configuration of bedrock in the area.

Extrapolating from the geophysical results, the two walls form the interior corner of an $8.9 \times 8.2 \mathrm{~m}$ space of approximately $73 \mathrm{~m}^{2}$. The area between the two walls revealed no floors, internal divisions, or deposits that could provide information about the use of the space (online fig. 2). Rather, excavations revealed only a series of LBA fills. A deposit of stone collapse associated with the walls covered a thick and muddy deposit that probably represents the decay and collapse of mudbrick wall superstructures. Below this were deposits of fill that continued down to the mica-schist bedrock, which sloped steeply down to the north-northeast. Preserved just beneath the foundation level of the $2 \mathrm{~m}$ wide walls, a $0.05-0.10 \mathrm{~m}$ thick deposit of charred clays and silts contained a large number of burned wood fragments, a collection of burned and blackened bone, and a large group of charred ceramics. No signs of burning were identified on the wall stones themselves, and thus the deposition of the charred fill predates wall construction. Beneath the charred layer and immediately above bedrock, a layer measuring about $0.10 \mathrm{~m}$ thick of almost sterile mud was laid down, perhaps to level the surface. In ceramic terms, these fills contain mostly LB 1 material, with a few distinctive LB 2 fragments indicating the date of deposition. An earlier LB 1 date for the burned material is suggested also by radiocarbon analysis of a charcoal sample dating to the 18 th -17 th centuries B.C.E.

A less substantial later building phase in the area is represented by a finely finished fieldstone wall of dry-stone or mud-mortar construction (81.551.12) located immediately below topsoil in the southwestern corner of the area. Wall 81.551 .12 was $0.65 \mathrm{~m}$ wide and stretched approximately $2 \mathrm{~m}$ in a southeast-northwest 

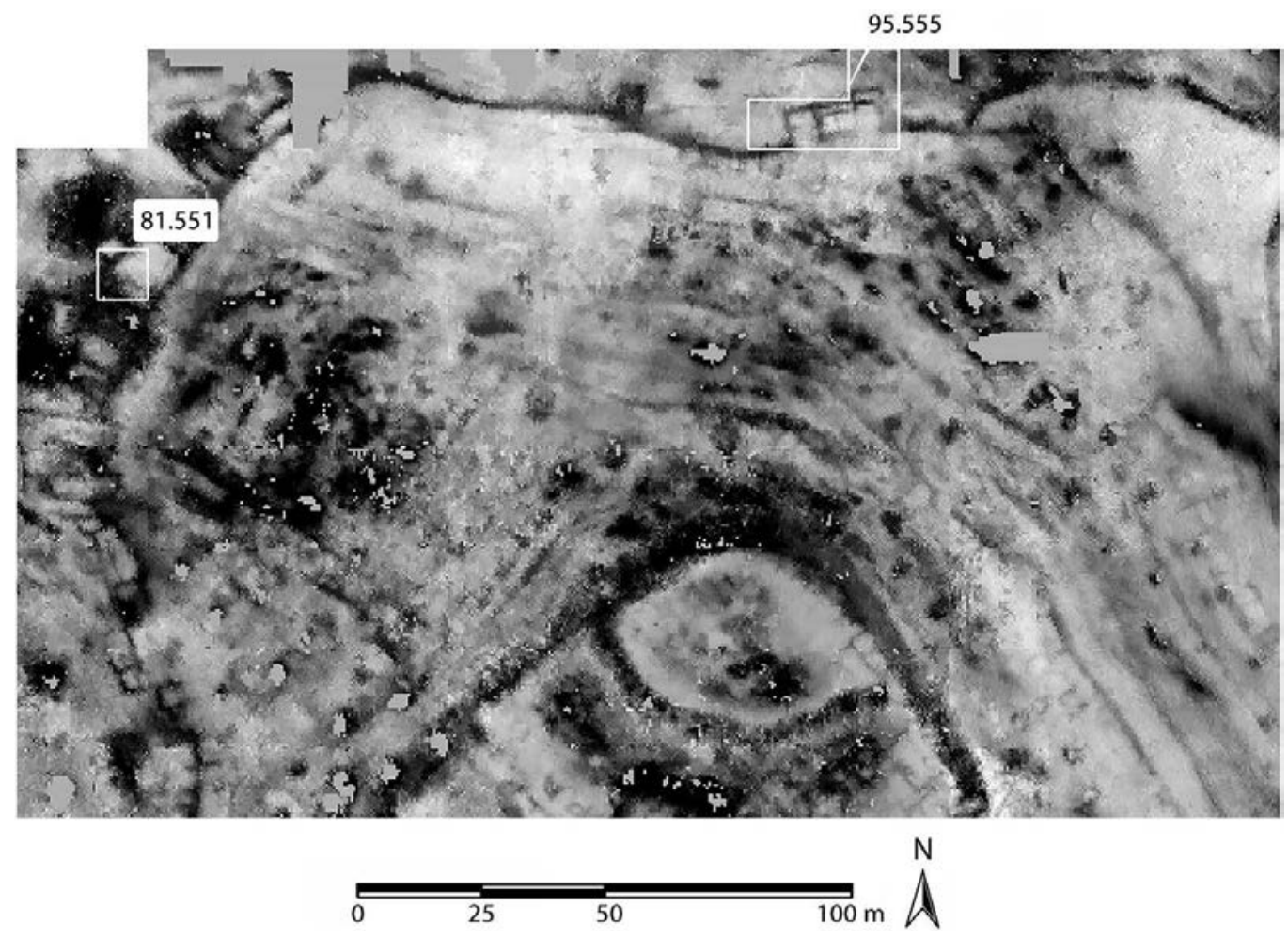

FIG. 3. Map of Kaymakçı showing excavation areas (outlined) located along the fortification wall superimposed over the results of resistance survey. High-resistance areas (e.g., walls, bedrock) are darker; low-resistance areas (e.g., earthen fill) are lighter (ㄷ Gygaia Projects).

orientation before continuing into the scarps. Roof tiles found here suggest a later date for this wall.

Excavation area 95.555. The aim of excavations in this elongated area situated at the northern edge of the citadel, along a break in slope that separates terraced interior spaces from the natural slope of the ridge, was again to investigate the nature and date of features of the fortification system suggested from geophysical results. These results showed the existence of a gatelike feature in the fortification wall as well as associated structures. An L-shaped excavation area was defined by a $9 \times 29 \mathrm{~m}$ area oriented east-west with an additional $9 \times 9 \mathrm{~m}$ area appended to the north at the eastern end. Excavations in 2015 exposed several LBA phases of the fortification system - namely, a curtain wall that appears to have been cut through for the addition of several other structures, including a possible tower and gateway (fig. 5, online fig. 3).

The earliest phase is represented by the construction of the fortification wall, segments of which (95.555.21, 182 , and 123) appear to represent a once-continuous section of curtain wall that geophysical results suggest

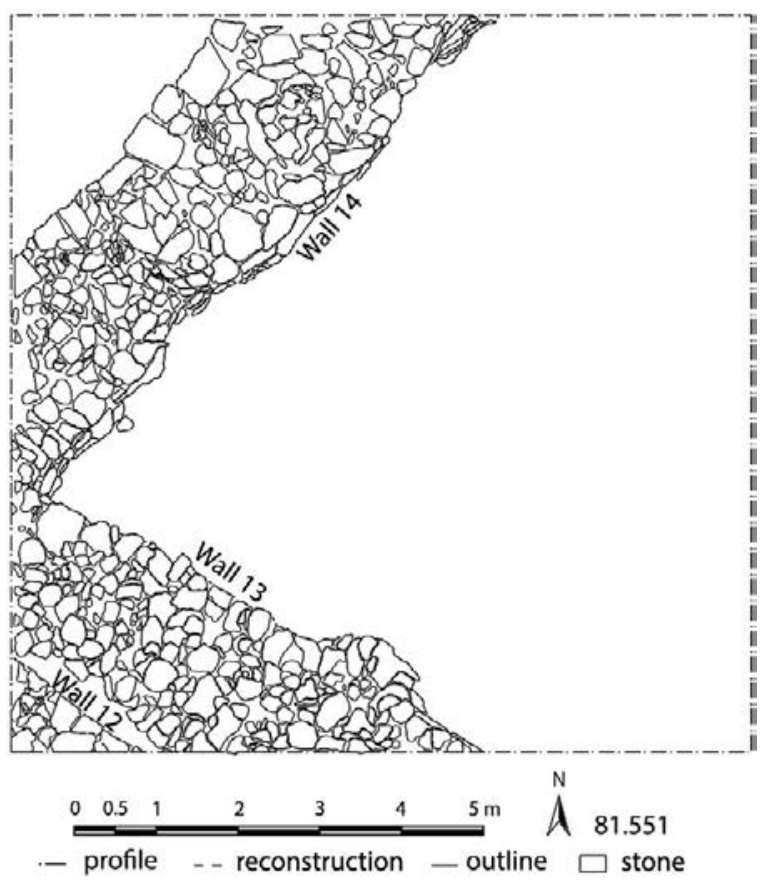

FIG. 4. Plan of excavation area 81.551 ((C) Gygaia Projects). 


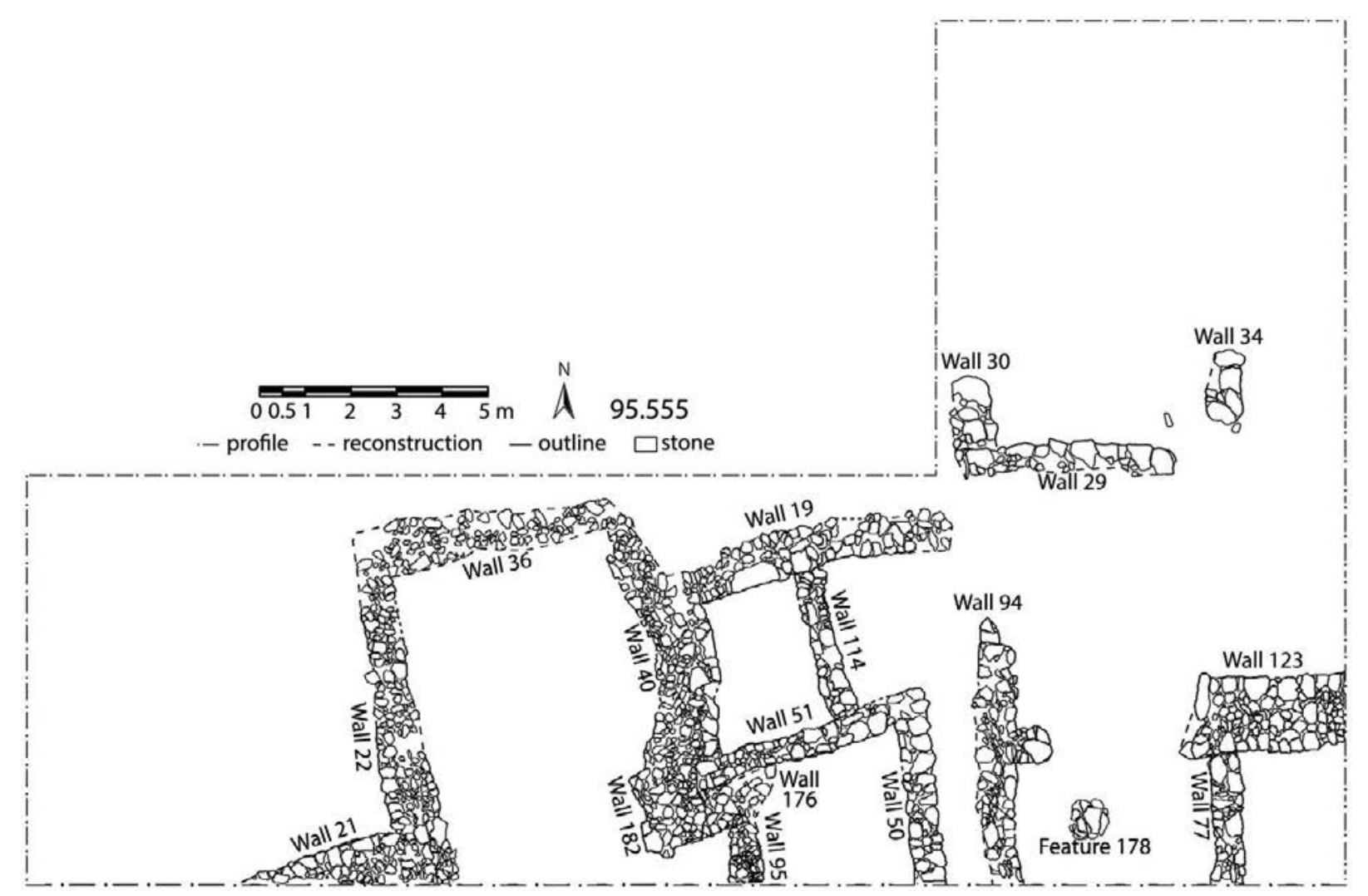

FIG. 5. Plan of excavation area 95.555 (C Gygaia Projects).

continues to east and west. Each segment was built in a manner similar to the "rubble core" walls of 81.551, with widths reaching up to $1.8 \mathrm{~m}$.

In the second architectural phase the once-continuous curtain wall was likely cut and additional structures added. To the east, two parallel walls (95.555.94 and 77) define a roughly $4 \mathrm{~m}$ wide, north-south oriented space, perpendicular to the main fortification wall, and suggest a gateway. Wall 95.555.77 extends north 2.5 $\mathrm{m}$ from the southern scarp, where it abuts the south face of the truncated curtain wall, approximately 0.50 $\mathrm{m}$ east of where it had been cut. Wall 95.555 .94 also extends north from the southern scarp and was preserved to a length of $5.1 \mathrm{~m}$. Along its eastern face, a spur wall measuring about $0.60 \mathrm{~m}$ long projects eastward, just opposite the segment of truncated curtain wall. Finally, a round stone feature (95.555.178) was located between walls 95.555 .77 and 94 .

Three other wall segments may belong to the second phase, the only architecture uncovered in the northern extension of the area. Walls 95.555.29, 30, and 34 are very similar in construction to the walls of the possible gateway. Wall 95.555.29 was exposed to a length of about $4.6 \mathrm{~m}$ and was oriented east-west, perpendicular to walls 95.555 .77 and 94 . The roughly parallel walls 95.555.30 and 34 were exposed only partially.

Likely also dating to the second architectural phase, a roughly square towerlike structure was constructed farther to the west as a projection from the outer northern face of the fortification wall, where it had been cut between wall segments 95.555.21 and 182 . The towerlike structure is represented by two parallel walls (95.555.22 and 40) that abut the fortification wall segments and project approximately $5.5 \mathrm{~m}$ to the north, where they bond with wall 95.555.36, also measuring about $5.5 \mathrm{~m}$ long and oriented perpendicularly to them.

A third architectural phase is attested by additional wall construction in the middle of the area. Two parallel east-west oriented walls (95.555.19 and 51) abut the exterior eastern face of the roughly square towerlike structure to the west. Wall 95.555.19 was preserved to a length of about $5.7 \mathrm{~m}$; wall 95.555 .51 extends about $5.2 \mathrm{~m}$ to where it makes a bonded corner 
with another wall (95.555.50), which then extends approximately $3.6 \mathrm{~m}$ before disappearing into the southern scarp. The fourth and latest construction phase attested in the area is represented by wall 95.555 .114 that abuts both walls 95.555 .19 and 51 perpendicularly and forms an enclosed space between them.

\section{The Inner Citadel and Surrounding Slope}

The highest point of Kaymakçı is defined by an almond-shaped area of about $1,400 \mathrm{~m}^{2}$ that forms the core of the inner citadel (fig. 6). The wall that defines this core is roughly $1.5 \mathrm{~m}$ wide and defines two roughly quarter-circle-shaped arcs to the north and south. Abutting the southern arc is a terrace of slightly lower elevation, and farther south the natural sloping topography levels out just inside the curving wall of citadel fortifications to the southwest and before meeting a rectilinear wall to the southeast that separates the area from the southern terrace.

Excavation area 93.545. The aims of excavations in this $19 \times 19 \mathrm{~m}$ space on the upper terrace of the inner citadel were to uncover a section of circuit wall and associated structures along its northern edge and to determine the chronology and function of both the wall and the space it helps define. Excavations in 2015 and 2016 revealed a spatial division into two, with dates spanning the entire LBA: the northern edge of the area, where a segment of the circuit wall and associated features were uncovered, and the large open area to its south, where no standing architecture but at least 16 semi-subterranean circular features lacking clear spatial organization were identified (fig. 7).

The earliest phases of the area are represented by fragmentary walls. One early wall fragment (93.545.347) was partially exposed beneath a circular feature in the central part of the area (93.545.194). The wall, oriented southeast-northwest, was buried deep beneath the circular feature and unassociated with it; pottery from deposits abutting it date to a very early stage of the local LBA. A second early wall fragment exposed along the northern edge of the area beneath the later circuit wall (see below) was built directly above bedrock (93.545.349). Its truncation by the later wall and south-southwest to north-northeast orientation make clear its lack of association with the circuit wall and relatively earlier date.

Post-dating these early features, the circuit wall of the inner citadel was exposed to a length of about $10 \mathrm{~m}$ and measured $1.5 \mathrm{~m}$ wide where it was fully exposed in the northwest. Three continuous segments, designated as walls $93.545 .34 / 35,172$, and 174 , were punctuated by the construction of three "stub" walls measuring about 1-1.5 m long, bonded perpendicularly to the inner face of the main wall $(93.545 .20,175$, and 176). Fills deposited along the inner face of the wall and just above bedrock date to the LB 1 phase. Some of the ceramics found among the rubble collapse of the circuit wall date very late, to the final LBA/EIA phase.

Post-dating the primary period of use of the circuit wall and dating late in the LB 2 phase according to associated finds, the only other feature in the northern part of the area was a roughly constructed oven (93.545.171; removed after excavation and thus not appearing in fig. 7), found adjacent to and just west of stub wall 93.545.20, yet built into several layers of fill that had accumulated along the trace of the circuit wall. The oven was built within a $1.8 \mathrm{~m}$ diameter stone foundation and consisted of multiple courses of small cobbles capped with a baked earthen surface. The only remains of the superstructure were a few stones set vertically into the foundation ring, perhaps delineating an eastward-facing mouth.

The central and southern part of the excavation area is characterized by at least 16 semi-subterranean, roughly circular features. ${ }^{26}$ Twelve of these were excavated fully, and the remaining four appear to have been constructed similarly. All circular features varied in size, depth, plan, and construction, with an average diameter of $2.09 \mathrm{~m}$ and an average depth of $0.88 \mathrm{~m}$. All features were built using a combination of rockcut and drywall techniques; each had a concave, hewn bedrock floor and rock-cut and/or coursed-stone walls (fig. 8). The relative amounts of the various building techniques varied from feature to feature, and the features were not organized spatially with any clear logic: they seem to have been built haphazardly across the area and at different times. Yet, to be sure, substantial energy and care were given to their fine construction.

In all cases, the circular features were found filled with deposits containing a wide variety of items. Common finds included ceramics, lithics, spindle whorls, loom weights, a few small metal items, mudbrick fragments, animal bones (including a high percentage from wild species), and even one well-preserved human humerus. The fragmentation of pottery from the fills

\footnotetext{
${ }^{26}$ Only excavated circular features are numbered in fig. 7 $(n=12)$.
} 


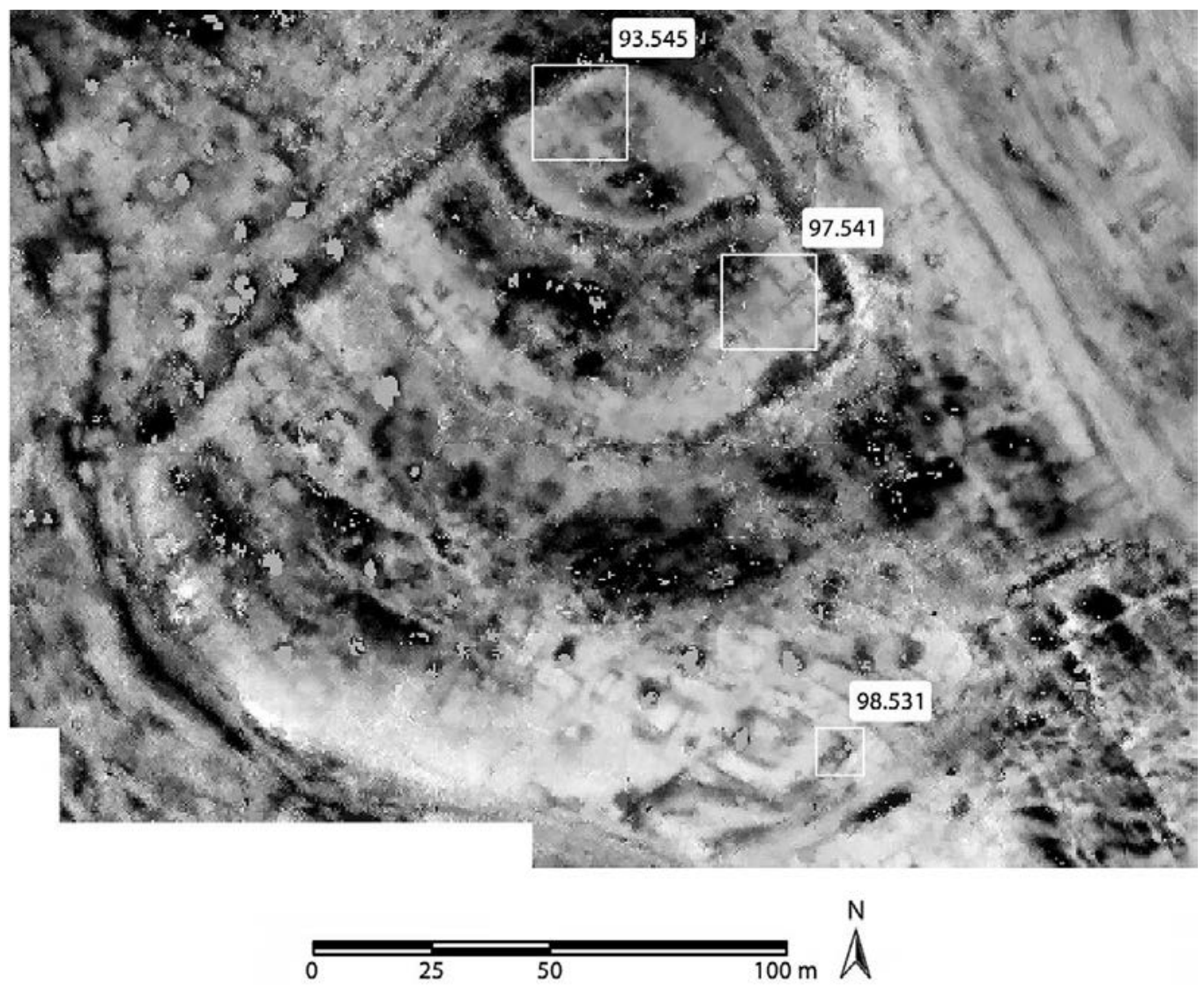

FIG. 6. Map of Kaymakçı showing excavation areas (outlined) in the inner citadel and surrounding slope superimposed over the results of resistance survey. High-resistance areas (e.g., walls, bedrock) are darker; low-resistance areas (e.g., earthen fill) are lighter (ㄷ Gygaia Projects).

varies, and the dates range across the LB 1 and LB 2 phases. Some circular features appear to have been filled already in the LB 1 phase (e.g., 93.545.63, from the lowest fill of which were recovered LB 1 pottery and burned wood that produced radiocarbon dates of the 18th-16th centuries B.C.E), while others were filled in the LB 2 phase.

Excavation area 97.541. The aims of excavation in this $19 \times 19 \mathrm{~m}$ area located on the lower, outer terrace of the inner citadel of Kaymakçı again included determining the character and date of activities delineated by architectural features already visible in geophysical results (fig. 9, online fig. 4). Excavations in 2015 and 2016 exposed at least three buildings and more circular features of LBA date.

The earliest apparent phase of activity is represented by circular features located in the northwestern part of the area, where the removal of shallow deposits of topsoil exposed mica-schist bedrock that appears to have been leveled in antiquity. Into the leveled bedrock in this area were hewn five circular features, some bolstered with drywall stone construction. Like similar structures in area 93.545 (above), they show no uniformity in size or depth, and they vary even more in form, with one example (97.541.182) described by a rounded-rectangular plan. Two other circular features were excavated farther to the south, for a total of seven excavated examples, while at least three others have been identified yet remain unexcavated. Like those in 93.545, the circular features in 97.541 may not all belong to the same phase. The secondary fills of 97.541 .184 date to the very beginning of the LB 1 phase, while others may be slightly later according to ceramics recovered from their fills. Their chronological relationship to the architecture of the area is demonstrated only by the stratigraphic relationship of one unexcavated and one excavated circular feature (97.541.436), both of which were covered by the con- 


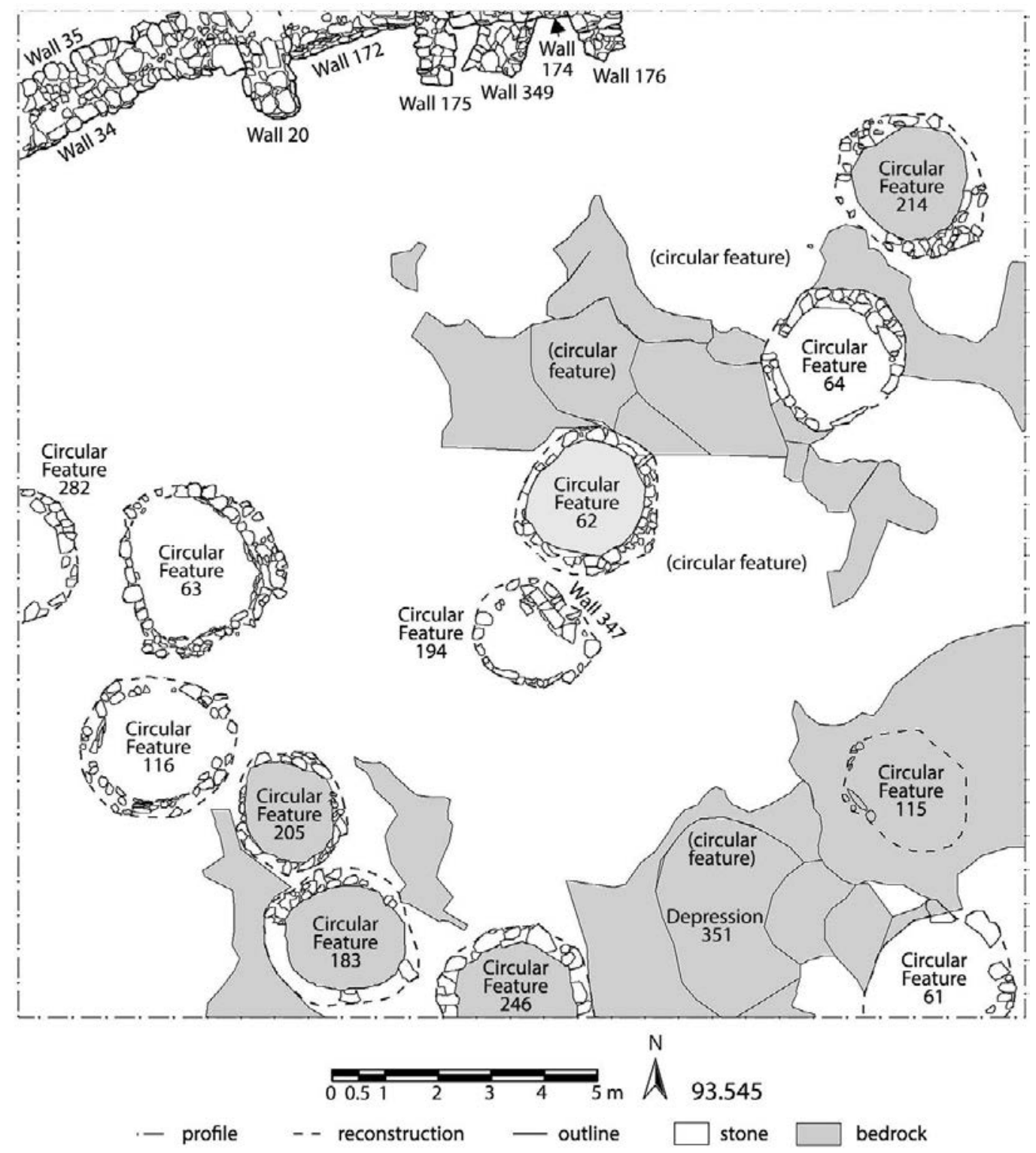

FIG. 7. Plan of excavation area 93.545 (ㄷ Gygaia Projects).

struction of a wall (97.541.36) belonging to a large building in the northeastern part of the area. The only other remains that likely date to a similarly early phase include two poorly preserved walls in the central part of the area (97.541.443 and 444), along with a few associated schist paving slabs.

The next phase of activity in the area is represented by only the foundations of several buildings or building complexes. In the northeastern part of the area, a large building is defined by two walls that join perpendicularly at a bonded corner. The previously mentioned wall 97.541 .36 is oriented southeast-northwest, mea- sures about $0.6 \mathrm{~m}$ wide, and was exposed to a length of about $10 \mathrm{~m}$ before disappearing into the northern scarp. Wall 97.541.55, oriented southwest-northeast and measuring about $0.7 \mathrm{~m}$ wide, was exposed to a length of roughly $11 \mathrm{~m}$ before disappearing into the eastern scarp. Subdividing the space created by these two long walls were two 1-2 m long walls (97.541.53 and 54, the latter with two courses of mudbrick preserved on it) that form an abutting corner in the northeastern corner of the excavation area. A partially preserved pavement of large and flat schist slabs 


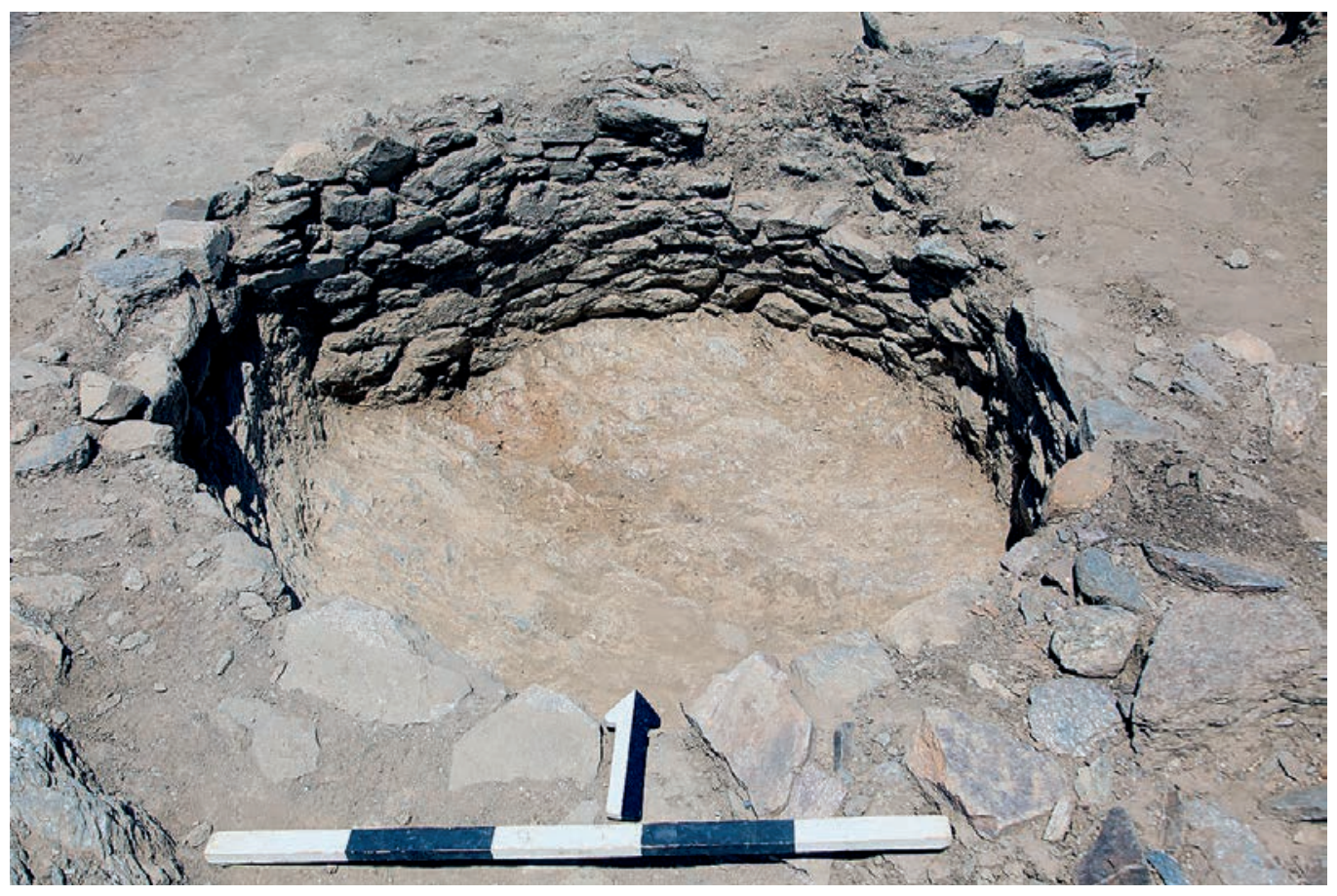

FIG. 8. Circular feature 93.545.214, looking north (ㄷ Gygaia Projects).

(97.541.94) shows that the remaining $6.7 \times 9.3 \mathrm{~m}$ space was paved.

Built at the same level as this building and separated from it toward the southeast by a corridor or alley about $1.3 \mathrm{~m}$ wide was a second building or building complex built on the same orientation. Wall 97.541.50, the wall that forms the southeast side of the corridor or alley, was exposed to a length of $9.7 \mathrm{~m}$ from the eastern scarp before making a bonded corner with wall 97.541.195, which is oriented perpendicularly and preserved only to a length of $1.3 \mathrm{~m}$. Wall 97.541 .50 may be paired with the parallel wall 193, which is preserved to a shorter length and presumably defines the southeastern wall of the building. Post-dating the construction of these parallel walls by some period of time, the building was divided internally by the construction of several shorter walls that abut the southeastern face of 97.541 .50 (walls 97.541.188, 190, and 194). Separated from this building by a narrow gap farther to the southeast, parallel walls 97.541 .440 and 198 perhaps belong to yet another building, with the remains of a cobblestone hearth (97.541.442) built against wall 198 , although their partial preservation and exposure in the corner of the excavation area preclude certainty. Ceramics associated with the fills in these spaces date roughly to the local LB 2 phase of the site, as do the fragments of Mycenaean Decorated Ware from an earthen pit (97.541.480) dug into these fills.

In the southwestern part of the area, several partially preserved walls form parts of one or more buildings of similar LB 2 phases. One wall oriented southeastnorthwest (97.541.96) was preserved to a length of approximately $9 \mathrm{~m}$ before turning $90^{\circ}$ to the southwest and running into the western scarp. Just south of and roughly parallel to wall 97.541 .96 were the remains of another wall (97.541.137), preserved along a roughly $6.5 \mathrm{~m}$ stretch that runs into the southern scarp. A stone pavement (97.541.102) like that in the northwestern building presumably belongs with one of these sets of walls, while a short fragment of another wall (97.541.103), oriented southwest-northeast, is presumably a remnant of earlier structures in this area.

Excavation area 98.531. The aims of excavations in this $9 \times 9 \mathrm{~m}$ area located at the southern, lower end of the slope outside the inner citadel included exploration of the date and character of activities suggested by architectural traces identified in geophysical survey and notably different from nearby buildings on the southern terrace (fig. 10). Excavations in 2014 exposed LBA walls defining a large, roughly square room and several spaces abutting it seemingly associated primarily with storage. 


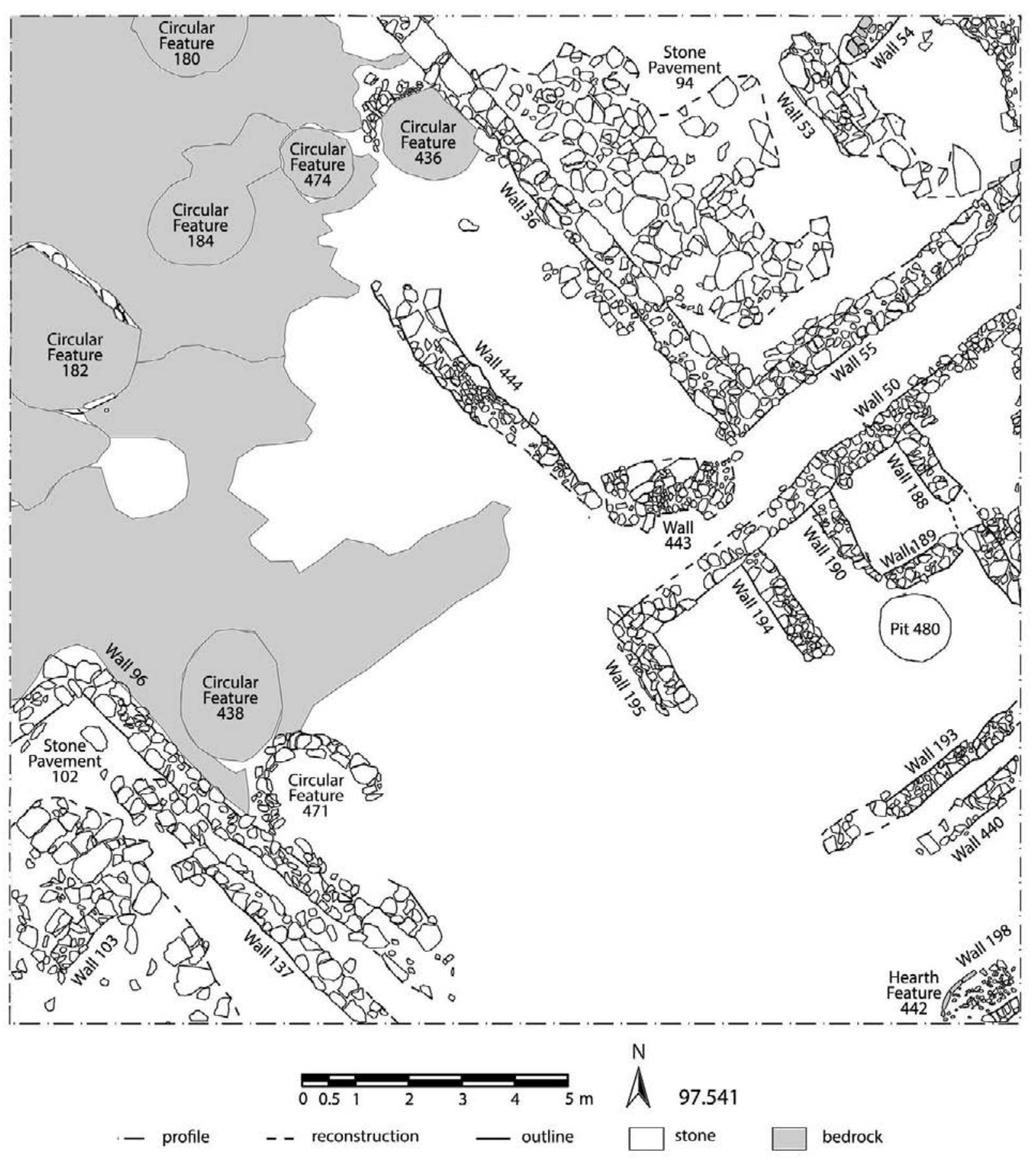

FIG. 9. Plan of excavation area 97.541 (C Gygaia Projects).

The earliest building phase is evidenced only by short segments of several poorly preserved one- or two-course wall foundations and associated surfaces (98.531.51, 54, 62, 63, and 66). The next building phase is represented by the construction of a roughly square, approximately $4 \times 4 \mathrm{~m}$ room (98.531.47) ori- ented southwest-northeast, enclosed on the northeast, northwest, and southeast by walls $98.531 .12,19$ and 20, with walls 98.531 .22 and 46 divided by a doorway measuring about $1 \mathrm{~m}$ wide on the southwestern side (fig. 11). The extension of wall 98.531 .20 about $2.5 \mathrm{~m}$ to the southwest beyond the room and into 


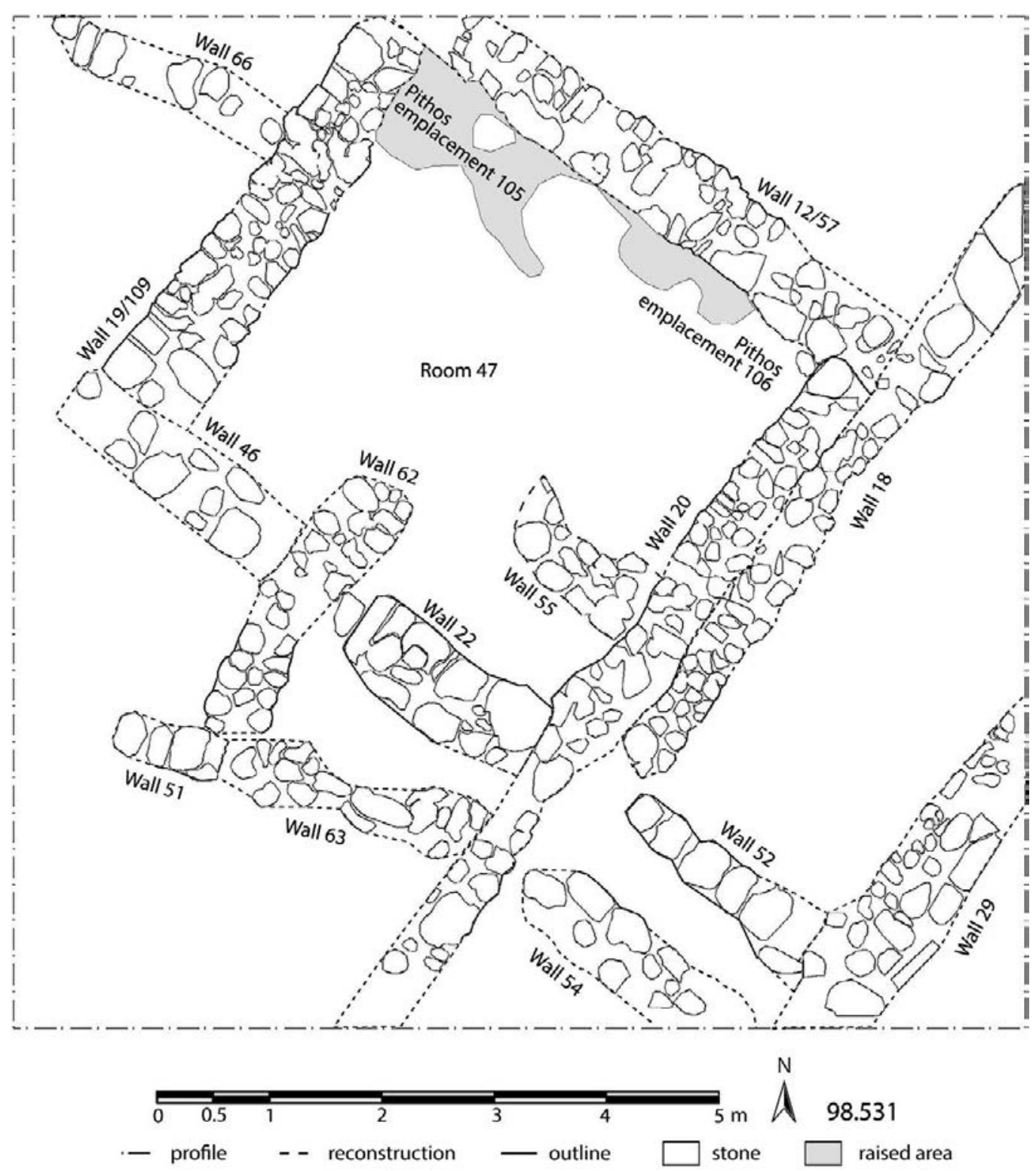

FIG. 10. Plan of excavation area 98.531 ( Gygaia Projects).

the scarp suggests this room was integrated within a larger building complex, a conclusion supported by geophysical results. The earliest activity in the room is represented by several shallow earthen pits and features abutting the northeastern wall, perhaps intended as pithos emplacements (e.g., 98.531.105). A thick layer of ashy and burned debris reflects a burning event that defines the end of this building phase, with radiocarbon dates on two seeds suggesting dates in the 17 th century B.C.E.

A subsequent phase of activity is represented by the rebuilding of walls 98.531 .12 and 19 above the ashy layer (98.531.57 and 109). During the same phase, several other features and walls came into use: a low $1.5 \mathrm{~m}$ long wall (98.531.55) was built to abut the southeastern wall; and an almost complete pithos (98.531.24; removed after excavation and thus not appearing in fig. $10)$ was set upside down into a stone-lined emplacement (98.531.106) in the eastern corner of the room. Pottery from associated fills date to both the LB 1 and LB 2 phases. About the same time, wall 98.531 .18 was built along the southeastern exterior of wall 98.531.20 and perhaps defined the western extent of an adjacent structure defined also by wall 98.531 .29 , built parallel 


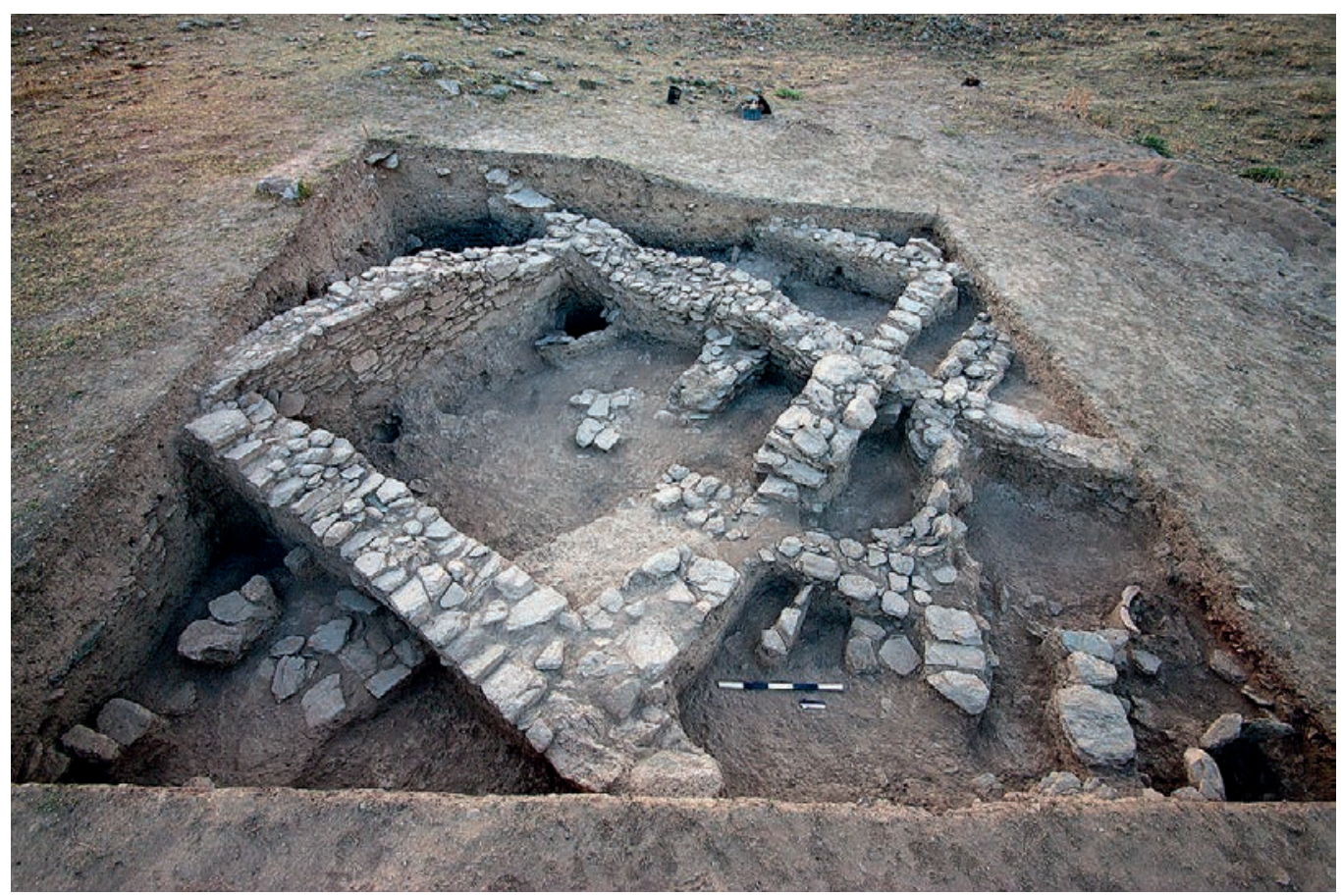

FIG. 11. Excavation area 98.531, looking east (ㄷ Gygaia Projects).

to it in the southeastern corner of the area, and, later, wall 98.531.52, which abutted wall 29 and closed off a space to the south. A radiocarbon date on a seed from a fill within the space between walls 98.531 .52 and 54 dates it to the 15 th century B.C.E.

\section{The Southern Terrace}

The largest discrete space within the citadel fortifications at Kaymakçı is the relatively flat southern terrace (fig. 12). The area is delineated on the northeast, southeast, and southwest by the line of the fortification wall and on the northwest by its junction with the slopes of the inner citadel and, in places, a roughly $2 \mathrm{~m}$ thick wall. Geophysical survey revealed the traces of numerous structures, some freestanding and others arranged in larger building complexes, separated in places by streets and alleys. The most apparent street is about $3-5 \mathrm{~m}$ wide and runs southeast-northwest through the middle of the terrace. Slightly different orientations define the building complexes on either side of this street, perhaps responding to both the needs of architectural organization and conformance to the local bedrock topography.

Excavation area 99.526. The aims of excavations in this $9 \times 9 \mathrm{~m}$ area on the southwestern side of the south- ern terrace, roughly $12 \mathrm{~m}$ inside the fortification wall, included investigation of the date and use of spaces clearly identified from geophysical survey (fig. 13). Excavations in 2014-2016 exposed a building complex and associated features dating to the late LB 1 and LB 2 phases superimposed above LB 1 features and fills that suggest the area was first used for open-air, exterior activities.

The earliest phases here are represented by evidence for cooking, production, and other activities in an area exposed between and beneath the level of three later walls (99.526.8, 9, and 50/51). Preliminary ceramic assessments indicate early LB 1 dates. The earliest items include two crucible-like features (99.526.356 and 574; removed after excavation and thus not appearing in fig. 13) in the central and northern part of the area, found at the same elevation as two fired-ceramic platforms in the northeastern corner of the area, each defined by a mudbrick rim (99.526.578 and 581). Immediately above these fired-ceramic platforms, several overlapping features were constructed (99.526.385, 386 , and 509), each composed of mudbrick rims, hardpacked fill, and layers of flat-laid sherds (online fig. 5). Buried in the soft fill between and around the firedceramic platforms and the sherd-paved features was the incomplete skeleton of a human fetus (99.526.440), 


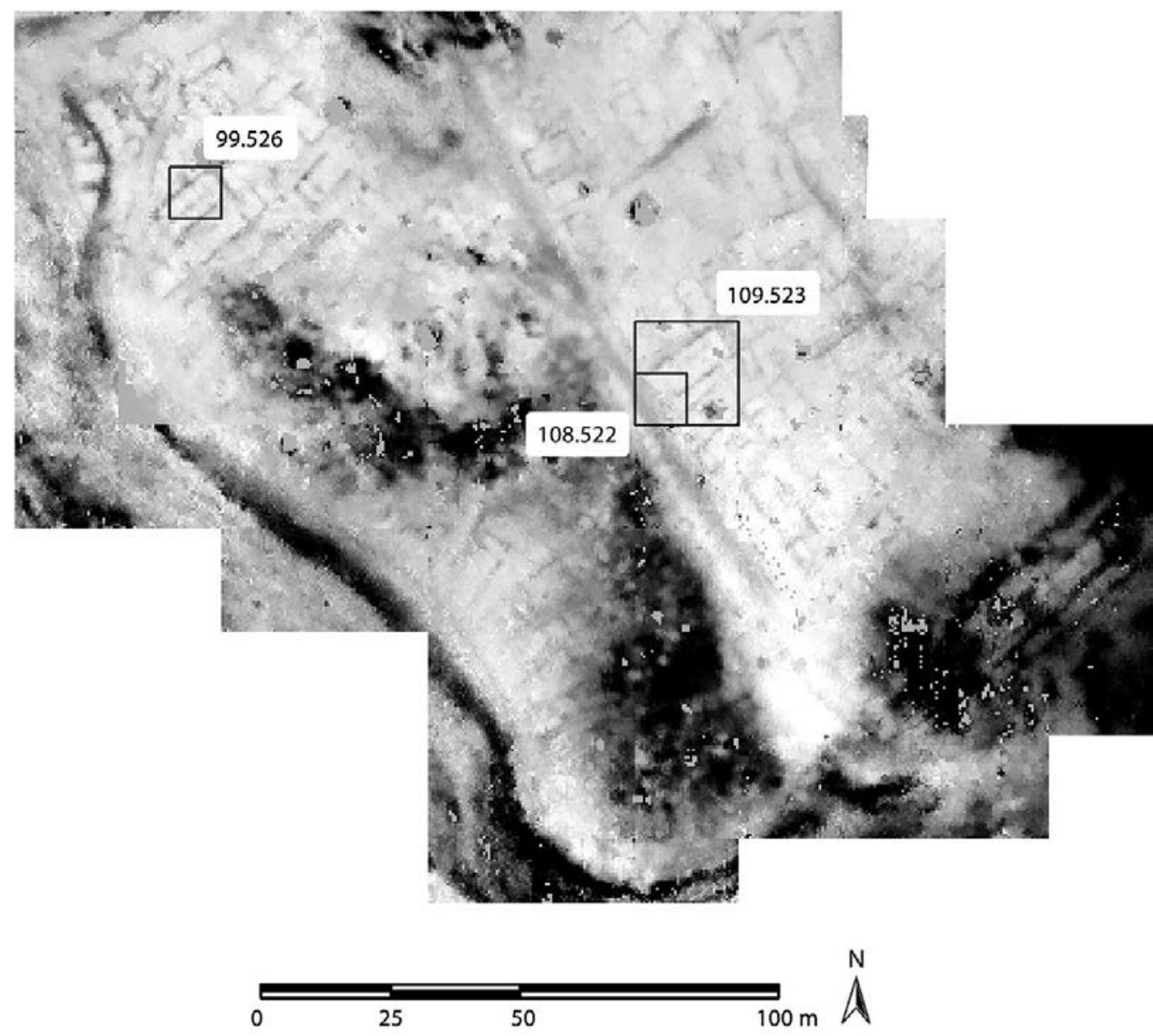

FIG. 12. Map of Kaymakçı showing excavation areas (outlined) in the southern terrace superimposed over the results of resistance survey. High-resistance areas (e.g., walls, bedrock) are darker; low-resistance areas (e.g., earthen fill) are lighter (@ Gygaia Projects).

and several other sets of animal bones were found elsewhere in these levels (99.526.439, 481, and 514), including a deposit containing incomplete neonate and juvenile animal skeletons in conjunction with that of a human fetus (99.526.573).

Also dating to these earliest phases of the area were three well-delineated pits (99.526.419, 556, and 557) and several very poorly preserved pebble, plaster, and/or mudbrick surfaces and stone-built features. One pit (99.526.419) had a homogenous red clay filling and was lined and covered with schist flagstones. The stone-built features included a wall fragment (99.526.376; removed after excavation and thus not appearing in fig. 13) and adjacent postholes (99.526.597 and 598) in the southern part of the area and, preserved at a higher elevation, two single-course wall fragments (99.526.124 and 125) exposed in the southeastern corner of the area. Slightly later but still in the primarily pre-architectural phases of the area, a large circular and mudbrick-rimmed oven (99.526.79) was constructed above pit 99.526 .419 along the western scarp, seemingly associated with remnants of a mudbrick surface preserved near the edges of the area (99.526.202, 213, and 264; removed after excavation and thus not appearing in fig. 13).

The second major phase of activity in the area occurred near the transition of the LB 1 and LB 2 phases. Built overlying the fragmentary mudbrick surfaces of the previous phase, a series of walls (99.526.8, 50/51, and 9 ) oriented southwest-northeast define two long spaces stretching from scarp to scarp while another wall (99.526.16) forms the northeastern end of the northern of the two spaces. Mudbrick surviving atop wall 99.526.51 suggests a mudbrick superstructure for 


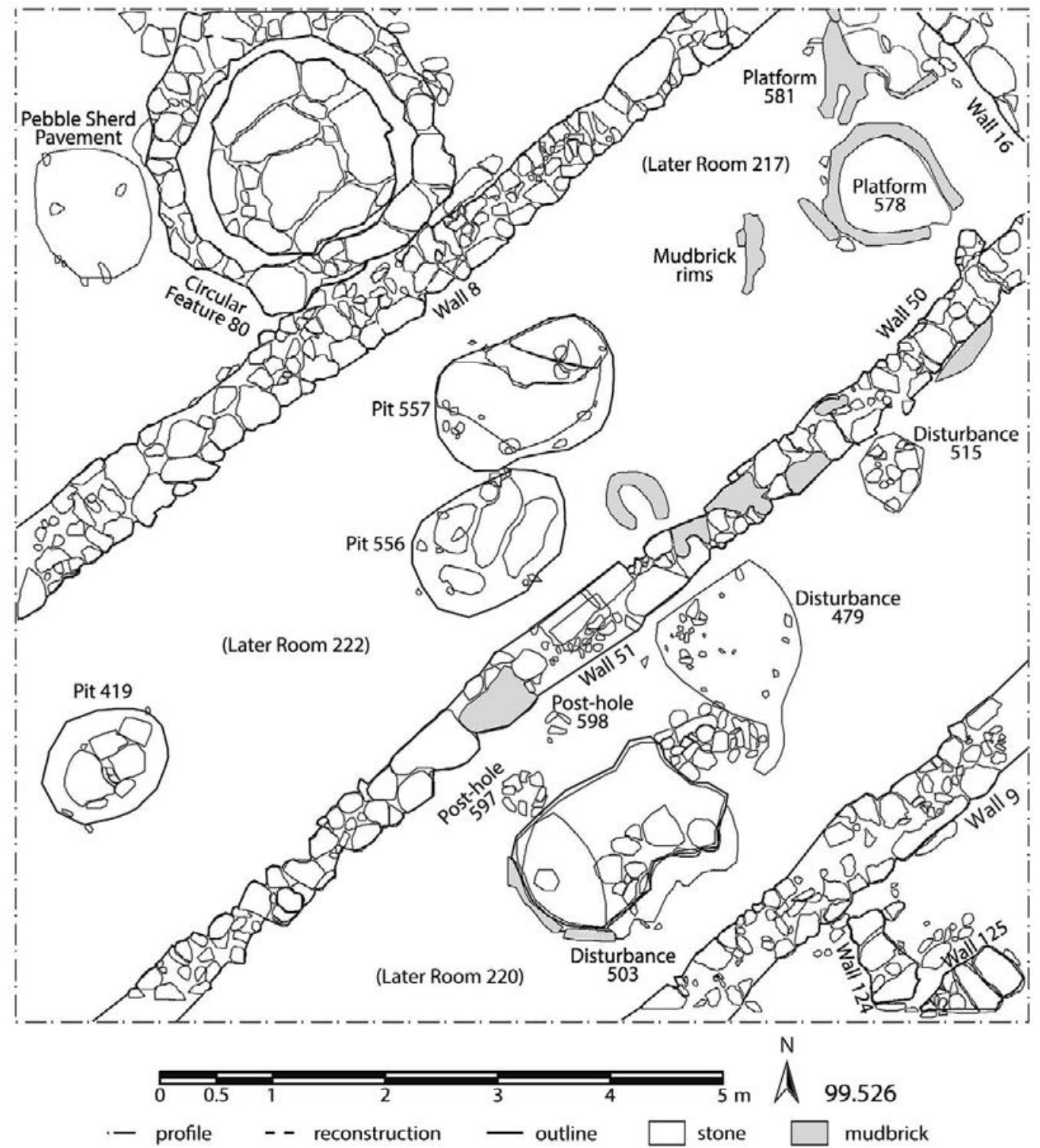

FIG. 13. Plan of excavation area 99.526, showing second phase of building activity and selected earlier features (c) Gygaia Projects).

this wall, while the stone coursing of walls 99.526 .8 and 9 was preserved to higher elevations. The northern of these two spaces was further subdivided by two aligned stub walls (99.526.114 and 115) that perpendicularly abut walls 99.526 .51 and 8 and extend about $0.5 \mathrm{~m}$ and $1 \mathrm{~m}$ into the room, respectively (these were removed after excavation and thus do not appear in fig. 13). In sum, this building had at least three rooms: a long room to the southeast measuring at least $9.3 \times 2.5$ $\mathrm{m}$ (99.526.220), a long room to the northwest measuring at least $8.6 \times 2.7 \mathrm{~m}(99.526 .222)$, and a small room to the northeast measuring approximately $2.5 \mathrm{x}$ $2.7 \mathrm{~m}$ (99.526.217).

The third and final phase in this area saw the reorganization of the building, apparently contemporary with a raising of floor levels. The mudbrick superstructure atop wall 99.526.50/51 was replaced with stone wall segments ( 99.526 .14 and 15; removed after excavation and thus not appearing in fig. 13) that raised the elevation of this central division to that of walls 99.526 .8 and 9 and provided communication between rooms 99.526 .220 and 222 via a $0.9 \mathrm{~m}$ gap between 
them paved with a threshold- or sill-like schist slab. Among minor additions to interior spaces, a semi-subterranean circular feature was built to the north of the building (99.526.80), abutting and partly overlapping the highest preserved exterior course of wall 99.526.8 (fig. 14). Like those of the inner citadel in size, the walls of this feature were built with fine, dry-stone construction, while its floor was made of flat schist paving slabs that supported vertically set, orthostate-like schist slabs in the lowest course of the walls. Among ceramics dating to the LB 2 phase of the site, the fill of the feature contained other schist slabs.

Excavation area 108.522/109.523. The aim of excavations in this $19 \times 19 \mathrm{~m}$ area located in the central part of the southern terrace was to investigate the construction and date of a wide street as well as the organization of activities associated with a large building complex identifiable in geophysical results (fig. 15, online fig. 6). Excavations in area 108.522 in 2014 were expanded to area 109.523 in 2015, exposing long, rectilinear buildings divided by narrow alleys and abutting the street.

The earliest phase in the area, perhaps of MBA or early LB 1 date, is represented by stratified fills buried deep beneath the street. Secondary deposits perhaps used to level the area in preparation for the street contained some very abraded MBA sherds. Radiocarbon analysis of a piece of charcoal associated with these secondary fills confirms their original date in the 21st19th centuries B.C.E.

The second phase in the area is characterized by extensive and organized building activity starting possibly in LB 1, even if the levels exposed so far are of LB 2 date. First, a complex of rectilinear buildings was built in parallel arrangement. The substantial wall 108.522.15, measuring $0.75 \mathrm{~m}$ wide and exposed to a length of $10.30 \mathrm{~m}$, marks the front of at least one large building in the center of the excavated units. The remainder of this building is demarcated by walls $109.523 .74 / 222 / 72,60$, and 71 , which define a rectangular space of about $7 \times 16 \mathrm{~m}$. Flanking this central building, a few contemporary buildings were only partially exposed. A rectangular building to the north was represented by wall 109.523 .54 and a narrow, $3.86 \mathrm{~m}$ wide building to the south by walls 109.523 .58 and 104. Complementing the more robust exterior walls of these buildings, shorter and less substantial walls were subsequently constructed to subdivide interior spaces, some of which were paved with schist slabs. The interior of the central building was divided into at least three rooms, the largest of which measured $8.20 \times 6 \mathrm{~m}$. Additionally, some of the roughly $1.8 \mathrm{~m}$ wide alleys between the buildings were fitted with pebble and sherd pavements. Some of them probably opened perpendicularly onto the main street, likely built about the same time, abutting the face of wall 108.522.15. Like the alleys, the street, too, was paved only informally, this time with small limestone pebbles and schist flakes. As exposed in this area, the street was at least $4 \mathrm{~m}$ wide and included four consecutive sublayers of alternating clay and pebble surfaces, about 0.60 $\mathrm{m}$ thick in total.

The third and final phase exposed in the area, again of LB 2 date, is characterized by another reorganization of space. Two circular features (108.522.21 and 22) were built between still-standing walls. Despite their poor preservation - only their schist-slab floors survive-they clearly resemble the better-preserved example from area 99.526. Additionally, the bottoms of three pithoi $(109.523 .64,65$, and 66 , the last of which does not appear in fig. 15 owing to its poor preservation) were preserved in situ in fills overlying the floor level of the northern building. These had probably been set into or below a no longer preserved floor level and represent the very latest phase of this area of the southern terrace.

\section{MATERIAL ECONOMIES AND FINISHED PRODUCTS}

Here we turn to discussion of evidence for material economies and, below, subsistence economies, highlighting their significance for understanding traditions local to the Marmara Lake basin as well as Kaymakçı's connections to regional communities. More detailed publication is in preparation for specific material categories.

\section{Production Zones}

Large-scale primary production within the citadel has yet to be attested: no kilns for firing ceramics, furnaces for metals, or smelting locations have been located. Excavations have yielded an abundance of finished products, however, and other data point to on-site production of both ceramic and metal goods. Previous macroscopic, petrographic, and chemical analyses of second-millennium ceramics found throughout the lake basin suggested local production. ${ }^{27}$

\footnotetext{
${ }^{27}$ See Luke et al. 2015 for the primary description of wares
} 


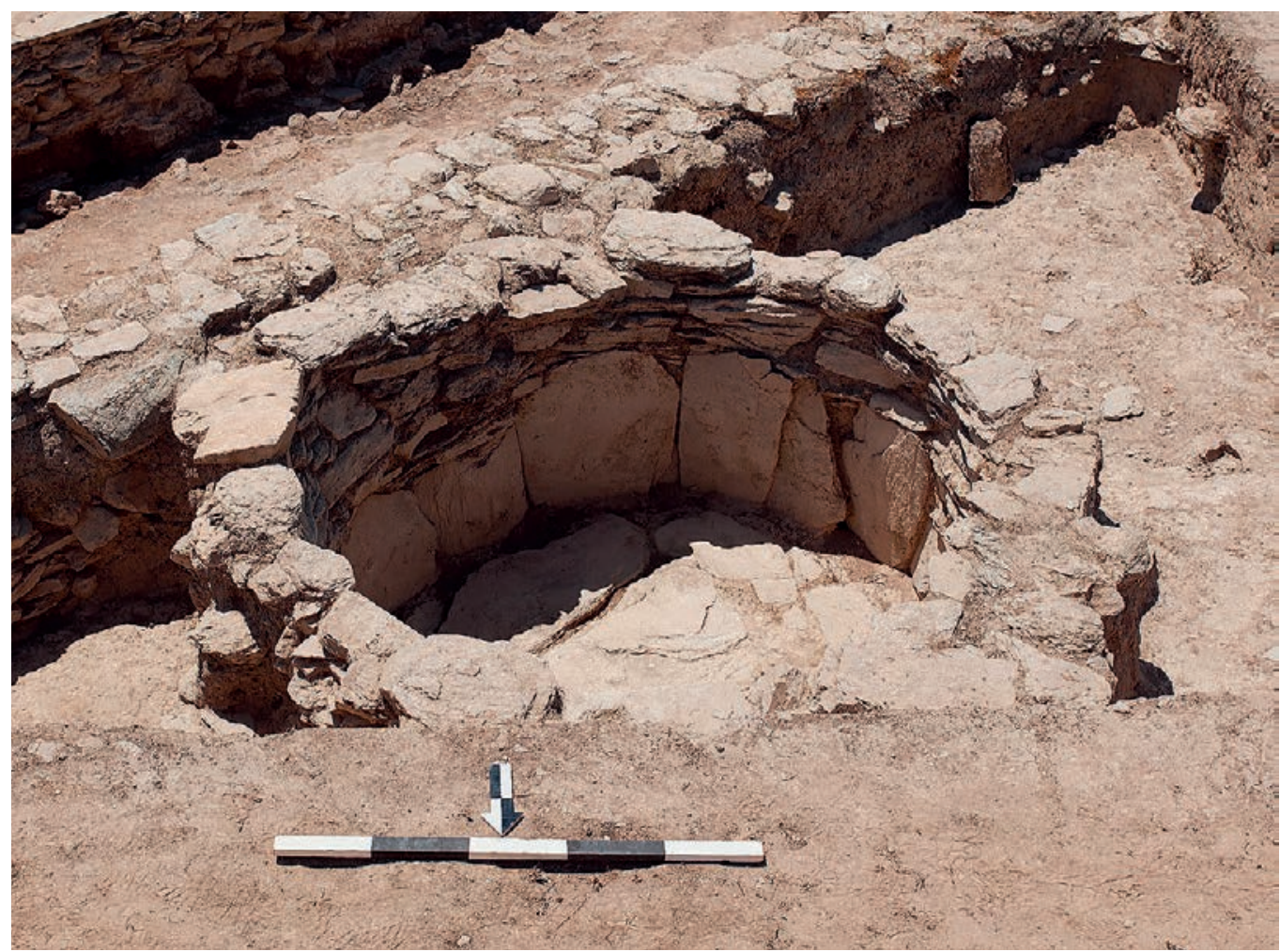

FIG. 14. Circular feature 99.526.80, looking south (C Gygaia Projects).

Ceramic slag, characterized by a porous, vitreous, or vesicular structure, is found in all but one excavation area (i.e., not in 99.526). ${ }^{28}$ Portable x-ray fluorescence (pXRF) elemental analysis conducted in the excavation laboratory shows the slag to be consistently iron rich with minor contributions from potassium and calcium. In contrast to slag, ceramic wasters deformed by exposure to high temperatures were found in only two areas (81.555 and 108.522). Elemental analysis of the wasters is consistent with the slag. In addition, given their lack of glassy material and elemental contributions from metals, the two crucible-like features from area 99.526 (99.526.356 and 574) may have been used in ceramic pigment production.

Evidence for metalworking activities, however, has been recovered. One sample of metallurgical slag was recovered from the inner citadel (97.541.312).

and shapes that follows.

${ }^{28}$ Contexts with ceramic slag include the following: 81.551.31.18; 93.545.199.160; 95.555.109.12; 97.541.6.314; 97.541.201.132; 98.531.98.8; 108.522.39.8; 108.522.51.9; 109.523.79.8; 109.523 .129 .12 .
Elemental analysis indicates the presence of copper, arsenic, and tin in the vitreous material, consistent with LBA metal artifacts recovered from Hattusa and Kerkenes Dağ, ${ }^{29}$ as well as with preliminary results of assays of metal tools and other items from Kaymakçı (see below). Finally, one apparent anvil stone (97.541.324) further suggests the processing of raw materials on site. ${ }^{30}$

\section{Ceramics}

The largest class of material from Kaymakçı is, unsurprisingly, ceramic. As at other sites of this period and area, most of the ceramics recovered from Kaymakçı represent activities including transport, storage, preparation, cooking, and consumption of food and drink. More than 160,000 individual sherds with a total weight of more than 11 metric tons were collected and documented between 2014 and 2016. The initial processing of the pottery targeted its thorough

\footnotetext{
${ }^{29}$ Lehner 2011, 62; 2015, 143-53.

${ }^{30}$ For evidence of LBA anvil stones in central Anatolia, see Maner 2014, 2017.
} 


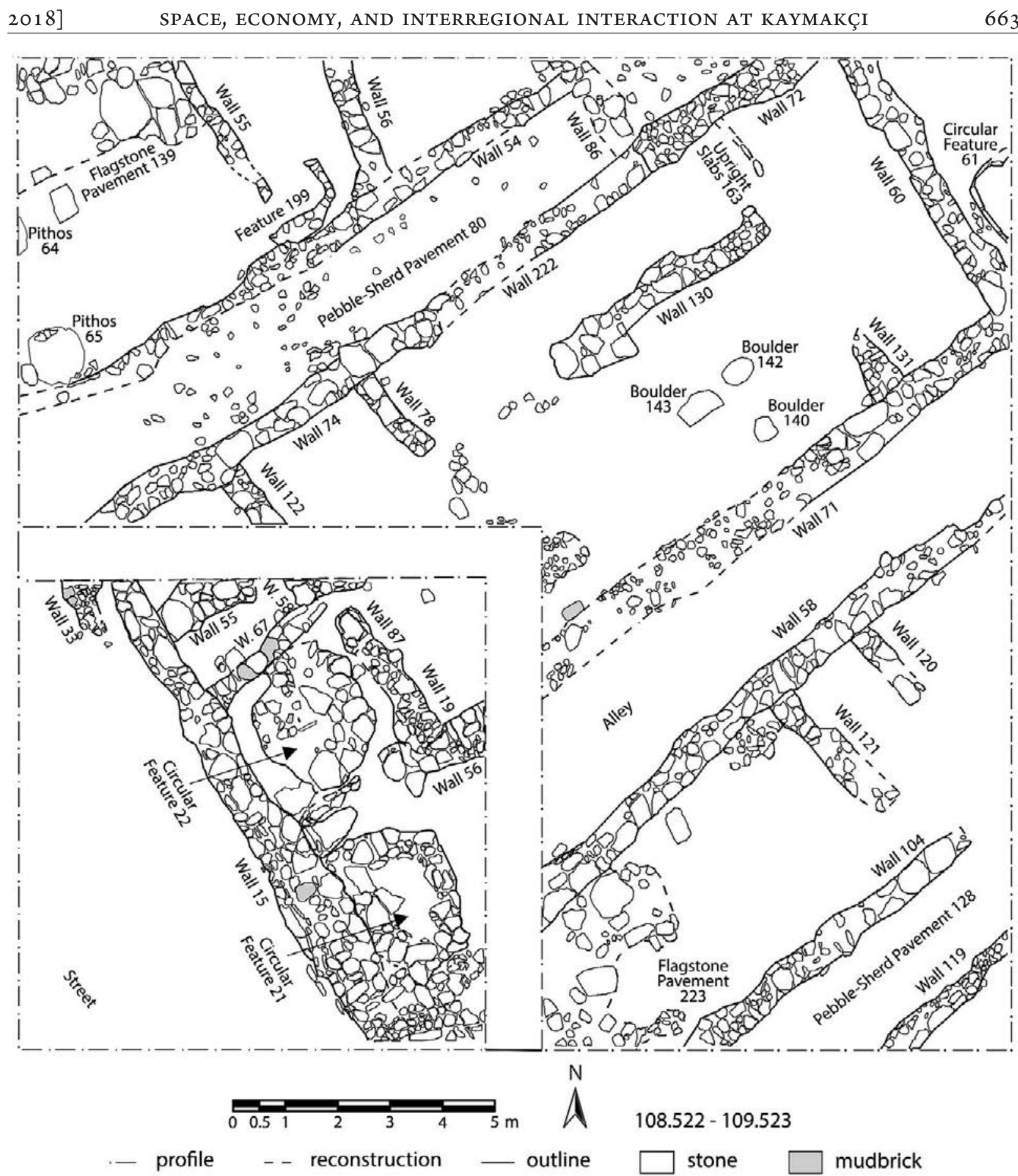

FIG. 15. Plan of excavation area 108.522/109.523 (C Gygaia Projects).

inventorying, along with stratigraphic and typological analyses. Only three cups, one of them two-handled (99.526.324.1, 99.526.452.1, 109.523.113.1), a small jug (95.555.66.1), a flask (99.526.58.1), and a lamp (99.526.550.1) were found in near complete condition (fig. 16); with the exception of a few partially restor- able coarse pots, the remaining vessels are represented by fragments.

Local wares accord with previously recognized traditions, including Red Light Brown (RLB) and Red and Brown Coarse (RBC) Wares, and Gray Ware, 


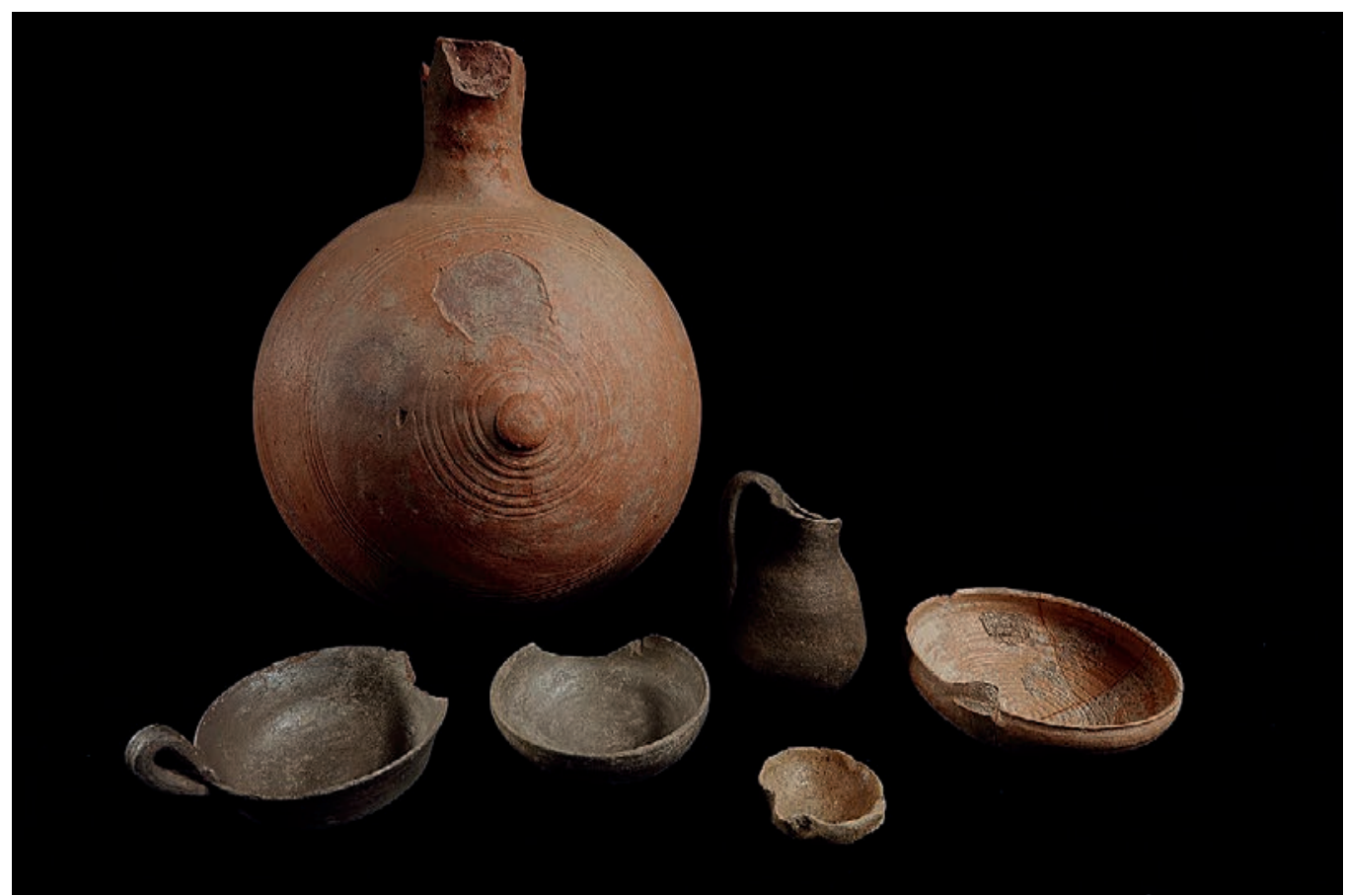

FIG. 16. Selection of complete ceramic vessels from the 2014-2016 excavations at Kaymakç1 in Red Light Brown and Gray Wares: rear, left to right, flask (99.526.58.1), small jug (95.555.66.1); front, left to right, lamp (99.526.550.1), cups (99.526.324.1, 99.526.452.1, 109.523.113.1) (N. Gail; C Gygaia Projects).

each with additional decorative varieties. ${ }^{31}$ The possible MBA and earliest LBA pottery spectrum includes also Red Slip Ware (RSW) and Burnished Plain Ware (BPW), linked through fabrics with the finer variety of the later RLB Ware. The most commonly found wareshape combinations include small RLB and Gray Ware cups, with flat bases and single vertical strap loop handles; medium to large RLB and Gray Ware bowls, with and without pedestaled bases and two horizontally attached basket handles (in rare cases also with a vertical loop handle); RLB jugs, most commonly with trefoil rims; RLB and RBC jars of varying closed, amphoralike and open, krater-like forms; RBC globular cooking pots with both round and flat bases; and RLB pithoi. Less common shapes include RLB spouted teapots, flasks, and at least one vessel interpreted elsewhere as a drum or incense burner. ${ }^{32} \mathrm{RLB}$ and Gray Ware vessels often carry ridged, grooved, and/or incised decoration

\footnotetext{
${ }^{31}$ Luke et al. 2015.

${ }^{32}$ Lloyd and Mellaart 1965, pl. 8, 17 (Beycesultan V). See Joukowsky 1986 for complex A4, phase II (Acropolis trench 8) and Bayne 2000 for Bayraklı level 11.
}

(mostly parallel lines, but occasionally also wavy lines), as well as gold- and silver-wash surface treatments, respectively. Less common surface treatments include red, brown, and sometimes even white-buff slip, burnishing (mainly an MBA and early LBA feature), and red-brown painted decoration in geometric patterns (likely a later LBA feature) (online fig. 7). Even rarer decorative traditions include plastic decoration of large bowls with rim-mounted theriomorphic protomes possibly representing horses, deer, dogs, or birds, and bowls or jars decorated with conical and spiral appliqués representing rams' and bulls' horns, and possibly snakes (mainly LB 1 but some also LB 2; online fig. 8).

General parallels with these assemblages are found in the second-millennium B.C.E. levels of sites excavated across western Anatolia, including Panaztepe, ${ }^{33}$ Liman Tepe (III), ${ }^{34}$ Bayraklı (10-14) and Larisa, ${ }^{35}$

\footnotetext{
${ }^{33}$ Günel 1999.

${ }^{34}$ Erkanal and Şahoğlu 2012, 227.

${ }^{35}$ Bayne 2000, 35, 69, 79 .
} 
Ulucak, ${ }^{36}$ Kocabaş Tepe and Çeşme-Bağlararası, ${ }^{37}$ Bademgediği Tepe ${ }^{38}$ Çine-Tepecik, ${ }^{39}$ Aphrodisias, ${ }^{40}$ and Beycesultan (V-II), ${ }^{41}$ and as far away as Troy (VI) ${ }^{42}$ and Gordion. ${ }^{43}$ Shallow plates or lids and tallstemmed cups or kylikes are very rare at Kaymakçı.

The three best-attested phases of occupation at the site-MBA, LB 1 , and LB 2 - are defined by changes in ceramic assemblages in addition to stratigraphic and architectural details. The evidence for MBA occupation typically consists of very worn burnished RLB sherds usually with thick red slip, redeposited in later contexts, often as construction fills. The first stratified assemblages occur as pit fills and mark either the end of the MBA or the very beginning of LB 1 . Represented shapes include simple lipless rounded bowls (in various sizes), carinated biconical lipless bowls, early variants of the so-called bead-rim bowls, all in BPW and RSW (fig. 17, nos. 1-5), but also early examples of Gray Ware (always burnished in this phase), retaining rounded or biconical shapes (see fig. 17, nos. 6, 7). Very distinctive are large bowls with richly profiled rims (see fig. 17, no. 8). Full-blown LB 1 assemblages show decreasing MBA characteristics, a relatively higher proportion of Gray Ware vessels, still commonly burnished, complemented by RLB and RBC vessels. Typical shapes include carinated cups with one handle and wide ranges of ridged bowls and carinated bowls, both with distinctly upright upper bodies, but some of the former still with bead rims and the latter with variously formed thickened lips (see fig. 17, nos. 9, 10). LB 2 assemblages show a decrease of Gray Ware in favor of examples of RLB, higher-temperature firing and thus harder wares, almost nonexistent burnishing, increased use of grooving, and occasional incised single wavy line and red painted decoration. Shapes include thinner-walled cups and small bowls (fig. 18 , nos. 1-5); stemmed dishes (see fig. 18, no. 6); a multitude of medium-sized carinated bowls (by now with everted upper bodies; see fig. 18, no. 7); a range of kraters (see fig. 18, nos. 8, 9); large bowls with mas-

\footnotetext{
${ }^{36}$ Çilingiroğlu et al. 2004.

${ }^{37}$ Aykurt 2010, 2013.

${ }^{38}$ Meriç and Mountjoy 2002; Meriç 2007, 31.

${ }^{39}$ Günel 2008, 136.

${ }^{40}$ Joukowsky 1986, 295, 323-27.

${ }^{41}$ Lloyd and Mellaart 1965, 80-1, insert 1; Mellaart and Murray 1995, 21-2; Dedeoğlu and Abay 2014.

${ }^{42}$ Blegen et al. 1953, 38; Pavúk 2014.

${ }^{43}$ Blegen et al. 1953, 38; Gunter, 1991, 29; Pavúk 2014.
}

sive thickened rims (see fig. 18, no. 10); and massive plates with rope imprints along the rim (see fig. 18, no. $11)$. Very typical of the LB 2 phase are fine pointed ring bases with interior grooved spirals residual from manufacturing (online fig. 9). The above mentioned final LBA/EIA ceramic phase still needs better definition, but it features distinctive jugs and carinated cups, as well as very sharply cut grooved decoration.

Several vessels have now been macroscopically identified as nonlocal imports, even if the origins of some remain undetermined. The body sherd of a cup with black fabric and slip found in a context probably dating to the LB 1 phase (98.531.77.16) is of unknown origin, as is the raised flat base of another cup from the LB 2 phase with high-luster polish on red slip (93.545.7.475). The former is likely an import, but the latter could be either an import or a very late sample dating to the final LBA/EIA phase. More closely identifiable was a pithos body sherd of distinctive pinkish fabric found in a context dating to the LB 1 to LB 2 transition (98.531.67.27); this fabric probably derives from the area of Miletus in the lower Maeander River valley. Finally, two sherds found in a pit (97.541.278.58 and 89) likely derive from two small stirrup or piriform jars of Mycenaean Decorated Ware (online fig. 10). One dates to Late Helladic (LH) IIIB and is likely of the Mycenae-Berbati compositional group (97.541.278.58); the other dates to LH IIIA2 or IIIB and is possibly from a different production center (97.541.278.89)..$^{4}$

Patterns in the assemblages suggest there may be more burnished Gray Ware from the fortification systems, perhaps an indication of an LB 1 date. In the inner citadel, the range and variation of ceramics are too great to allow generalizations at this time, except to say that the rich variety alone is worthy of comment. Chronologically they span very early LB 1 through LB 2 , complemented by an additional, even later ceramic phase whose date and character remain unclear. The evidence consists of both stratified occupation layers and the fills of the numerous circular features, showing a range of depositional processes. Area 98.531, on the lower slopes of the inner citadel, yielded numerous pithos fragments. The southern terrace produced the best chronological data - predictably, given the good preservation and deep stratigraphy. Pottery shapes

\footnotetext{
${ }^{44}$ P. Mountjoy, pers. comm. with C.H. Roosevelt, December 2016.
} 


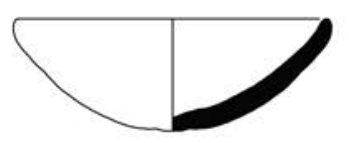

1: 97.541 .111 .76

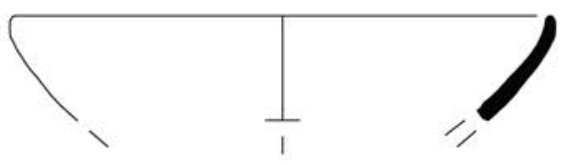

2: 97.541 .111 .108

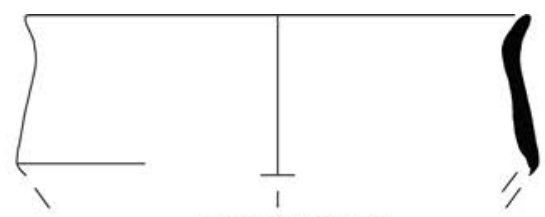

3: 93.545 .286 .74
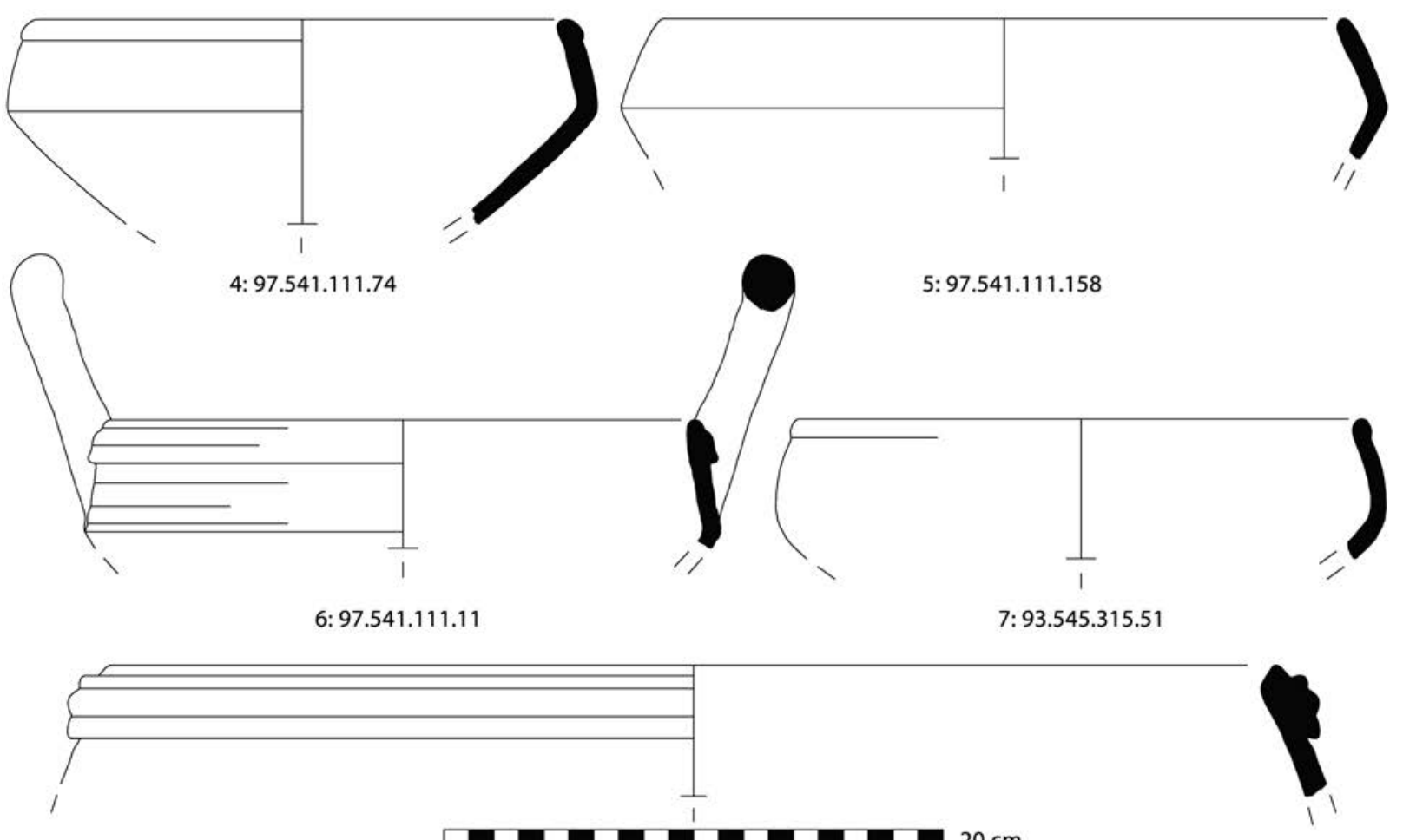

8: 97.541 .111 .187

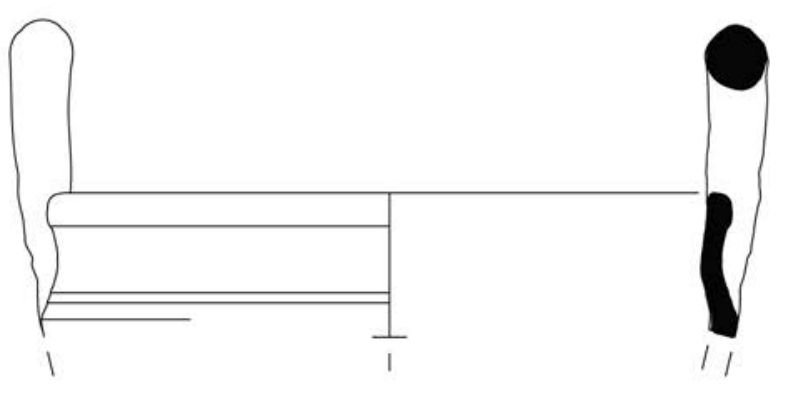

9: 99.526 .34 .43

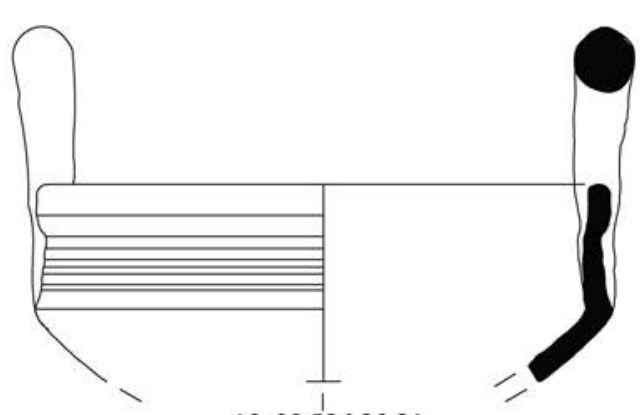

$10: 99.526 .30 .21$

FIG. 17. Selection of chronologically representative ceramic shapes from the MBA/early LB 1 phase (1-8) and the LB 1 phase (9-10, two examples of LB 1 carinated bowls with upright shoulder). Plain Burnished Ware: 1, 3, 4, 8; Red Slipped Ware: 2, 5; Gray Ware: 6, 7, 10; Red Light Brown Ware: 9. Scale 1:3, except for 8 ((C) Gygaia Projects). 

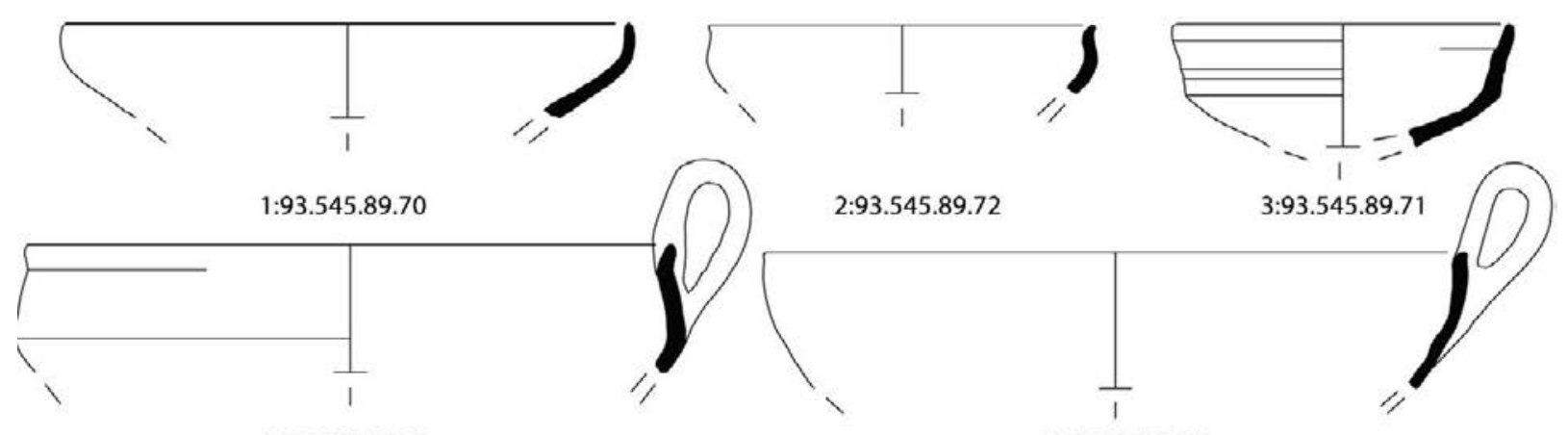

4:93.545.89.73

5:99.526.75.30
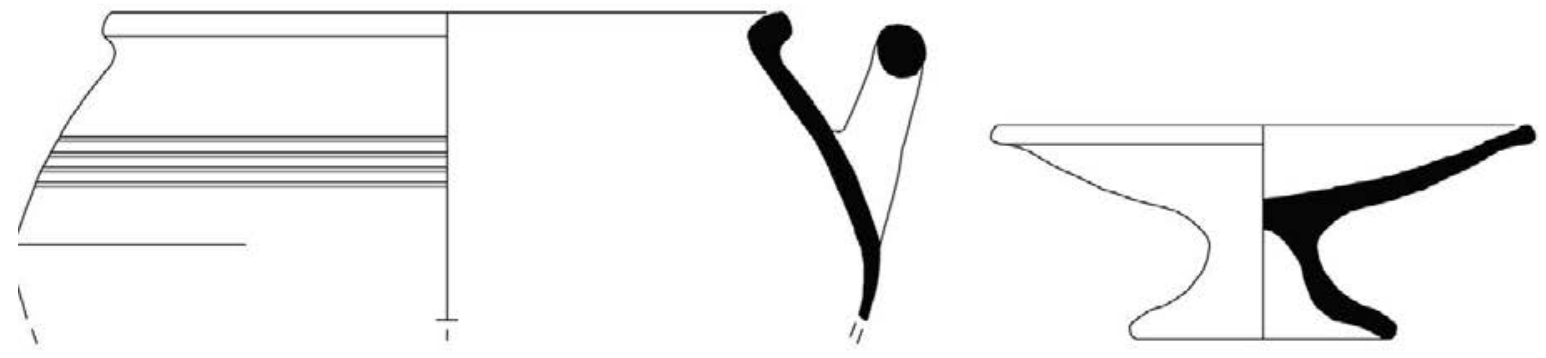

$8: 93.545 .37 .63$

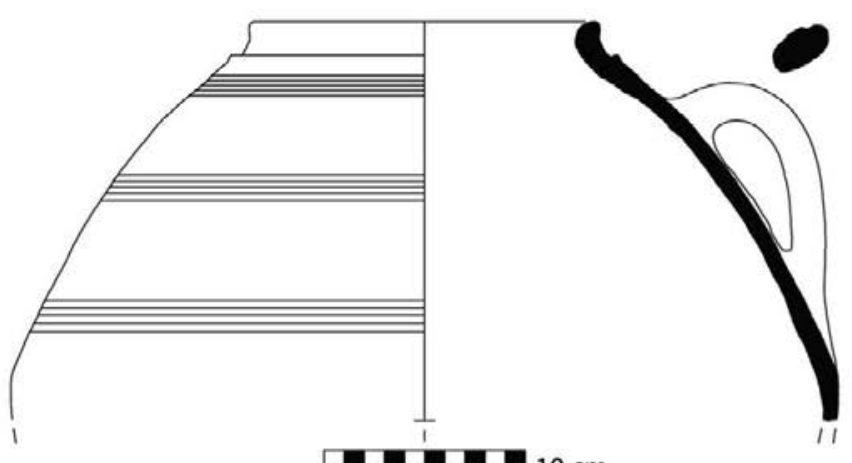

9:109.523.141.2

$6: 97.541 .382 .1$

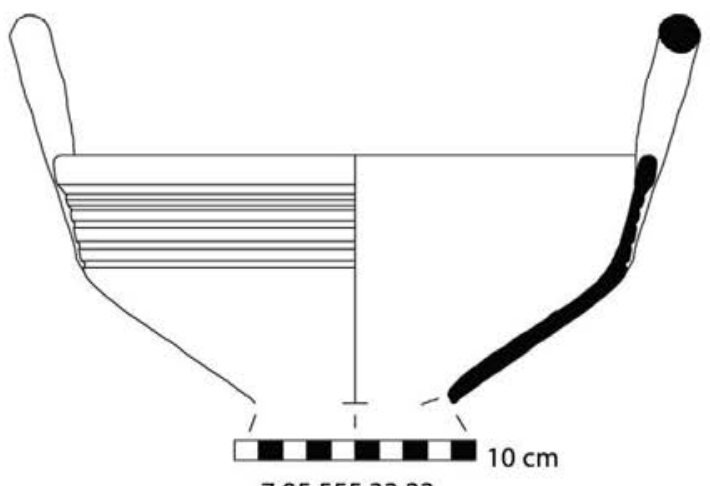

7:95.555.32.22

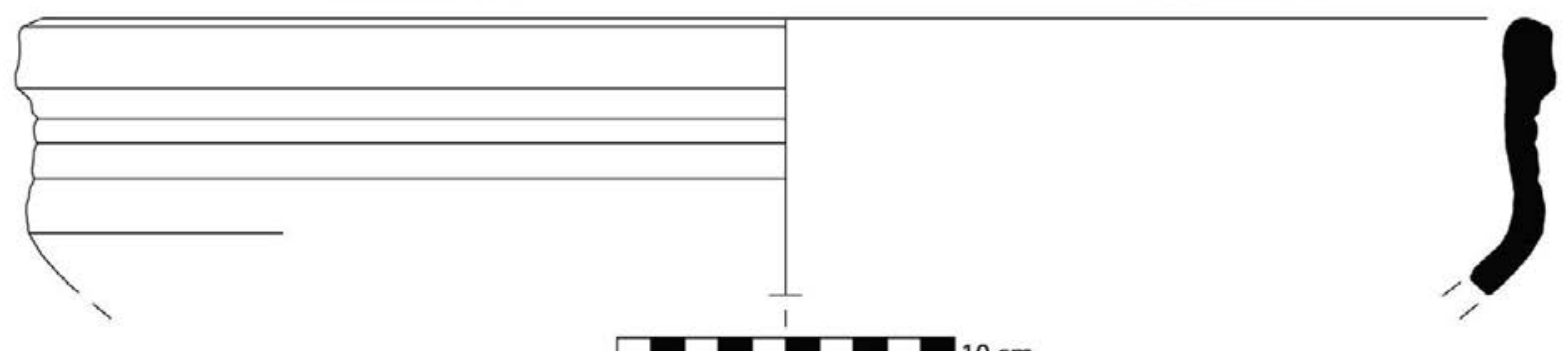

$10: 93.545 .102 .131$

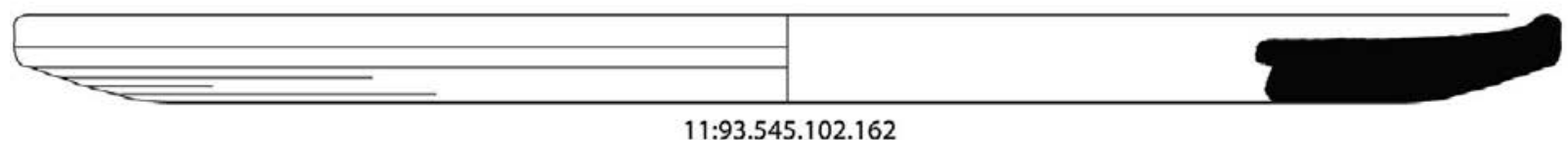

11:93.545.102.162

FIG. 18. Selection of chronologically representative ceramic shapes from the LB 2 phase. Red Light Brown Ware: 1, 2, 4-6, 9-11; Gray Ware: 3, 7. Scale 1:3, except for 7, 9, and 10 (ㄷ Gygaia Projects). 
and wares differ insignificantly among the southern terrace excavation areas, yet their depositional and post-depositional processes differ clearly from those of the inner citadel and fortification areas, as described above. Area 99.526 presents distinct LB 1 and LB 2 stratigraphy, while the MBA sherds from beneath widespread LB 2 occupation in area 108.522/109.523 suggest earlier levels.

\section{Textile and Other Material Production}

After ceramics, the second most numerous class of identifiable worked material recovered from Kaymakçı-which includes spindle whorls, loom weights, and needles - reflects textile production. To date, 120 spindle whorls of the conical or biconical form common in western Anatolia have been recovered (fig. 19, no. 1)..$^{45}$ These, like the local ceramic vessels, occur in two wares, with 58 examples similar to RLB Ware and 62 similar to Gray Ware, usually with smooth if not burnished surface treatments rendering the Gray Ware varieties nearly black in color. Sixty-five examples are plain, while 51 are decorated with a variety of symmetrical designs including Vs, radii, concentric circles and semicircles, and wavy lines, most commonly found on the shorter conical surfaces of biconical examples and on the bottoms of conical examples. In addition to form and decoration, the spindle whorls vary significantly in weight $(4.5-40 \mathrm{~g})$ and diameter, indicating use for making different gauges of yarn for different types and qualities of textiles, ${ }^{46}$ notably in wool, as suggested by evidence for the management of sheep and goats (see below).

Other implements found at Kaymakçı also suggest production of differing types of textiles. Only two intact examples (108.522.57.13 [see fig. 19, no. 2]) and 97.541.119.5, weights $194 \mathrm{~g}$ and $395 \mathrm{~g}$, respectively) and three fragments of purpose-made trapezoidal loom weights have been found; they are similar to examples excavated from roughly contemporary contexts elsewhere. ${ }^{47}$ Excavations also yielded 572 reused and

\footnotetext{
${ }^{45}$ See, e.g., Blegen et al. 1953, figs. 296, 306-8; Blegen et al. 1958, 152, figs. 221, 222.

${ }^{46}$ Andersson Strand 2014, 208-10 (with additional bibliography); 2015, 44-8.

${ }^{47}$ E.g., Troy VI Late (Blegen et al. 1953, 31, fig. 305), Troy VIIa (Blegen et al. 1958, 18, fig. 221, nos. 37-88, 37-289, $37-$ 356), Troy VIIb (Blegen et al. 1958, 152, fig. 256, no. 37-286); and Beycesultan (levels, V-II, Mellaart and Murray 1995, 118, pl. 14). No crescent-shaped loom weights like those from the
}

perforated, as well as 458 unperforated, ceramic vessel sherds (online fig. 11) and six perforated objects made of mica schist of regular as well as only roughly rounded shape. The function of these items is unclear, and they show very little evidence of use wear, but perforated examples could have served as spindle whorls, loom weights, lids, or perhaps part of fishing equipment. ${ }^{48} \mathrm{~A}$ function as loom weights is very probable in the case of the largest pithos sherds with off-center perforations, weighing 85-715 $\mathrm{g}$ (see fig. 19, no. 3). Unperforated examples may simply have been unfinished.

Also suggesting the variety of fabrics produced at Kaymakçı, 12 bronze needles were recovered from the site to date (see fig. 19, no. 4). Their forms match well with examples found at contemporary sites, ${ }^{49}$ yet their variety in size is notable. While needle lengths are rarely fully preserved, examples occur with a range of looped-eyelet widths $(0.2-0.5 \mathrm{~cm})$ appropriate to different gauges of yarn and thus to sewing different kinds of material.

Various bronze, bone, and stone tools as well as fragments of bronze sheet and wire from Kaymakçı also reflect local production (fig. 20; online fig. 12). Twenty-four bronze awls or drills of varying sizes have been recovered, most of them pointed and tanged with circular or square cross-sections (see online fig. 12, no. 1). They may have been used by hand to make perforations, as chisels in various kinds of specialized work (e.g., smoothing and polishing small surfaces, applying incised decoration, shaping of small objects) or as bits in hand- or bow-driven drills. The types are attested elsewhere in second-millennium B.C.E. contexts, yet the large number recovered from Kaymakçı in only three years of excavation is notable. ${ }^{50}$ Two other bronze tools are rarer: one is a large punch with blunt head

MBA (Lassen 2013) and LBA (Mellaart and Murray 1995, 118) at Beycesultan, Aphrodisias, and other Anatolian sites have been found at Kaymakçı.

${ }^{48}$ Roughly formed weights are common at Aphrodisias (Joukowsky 1986, 674-76, pl. 483). Rounded sherds could be especially suitable for high-whorl spindles (Andersson Strand 2015, 45-7, fig. 2.10b).

${ }^{49}$ Beycesultan (Mellaart and Murray 1995, 114-17, figs. O.3-7, O.11), Troy VI (Blegen et al. 1953, pl. 297, nos. 35-565, 38-109; Schalk 2008, 192-93, figs. 13, 14).

${ }^{50}$ Five awls are known from Troy (Blegen et al. 1953, 22; 1958, 149), six from Beycesultan (Mellaart and Murray 1995, 128-37) and 210 from Hattusa (Boehmer 1972, 115; 1979, 24 6), all in bronze. 


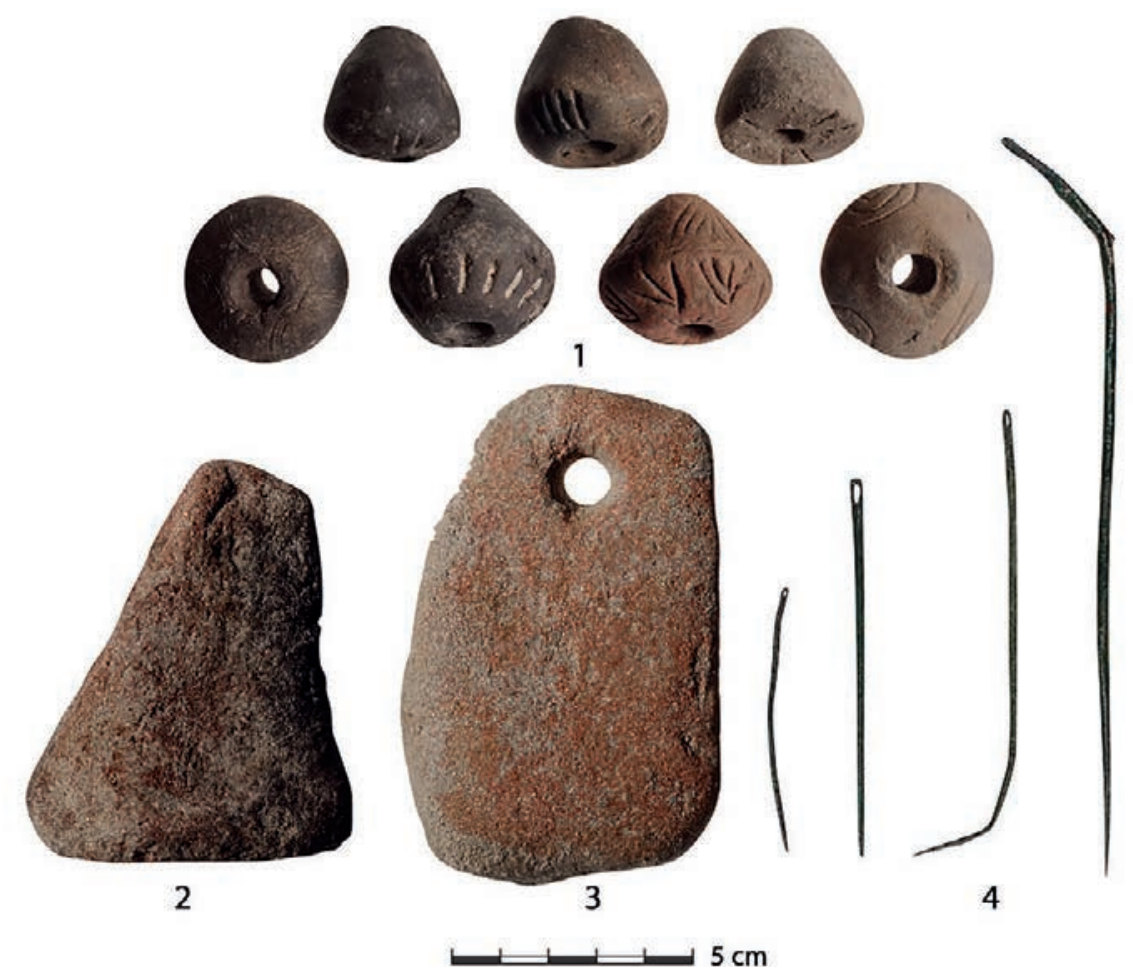

FIG. 19. Selection of tools from Kaymakçı associated with textile production: 1, clay spindle whorls; 2, 3, ceramic loom weights (108.522.57.13, 97.541.226.1); 4, bronze needles (N. Gail; (C Gygaia Projects).

(108.522.7.9; see fig. 20, no. 1; online fig. 12, no. 2), perhaps used for indirect beating or hammering or for making holes in harder materials such as metal sheet. ${ }^{51}$ The second is exceptional: it is a dual-ended tool (98.531.23.6; see fig. 20, no. 2; online fig. 12, no. 3) with no obvious tang but rather two slightly different chisel-shaped ends. It could have been used by hand as a punch or as a tiny chisel, to smooth or to carve small and fine surfaces, or even as a cosmetic tool. ${ }^{52} \mathrm{~A}$ leafshaped bronze chisel with a cutting edge perpendicular to the wider plane of the blade (99.526.185.1; see fig. 20, no. 3; online fig. 12, no. 4) is also notable; it falls outside the standard repertoire of known Anatolian tool assemblages but has parallels from the 14th- and

\footnotetext{
${ }^{51}$ For a similar artifact described as an EBA "chisel" from Troy, but with rectangular section, see Hänsel 2014, 177, no. Sch 6213, pl. 9, no. 20. Comparanda are known from other Bronze Age Anatolian sites (e.g., Müller-Karpe 1994, 160-62, pl. 65, nos. 5-20: "chisel type 1 and type 2").

${ }^{52}$ Similar tools but with only one chisel head were recovered from other MBA-LBA Anatolian sites (e.g., Müller-Karpe 1994, 170, pl. 73, nos. 23-6: "chisel type 13").
}

13th-century shipwrecks at Uluburun and Gelidonya as well as from Enkomi and elsewhere. ${ }^{53}$

At least four bone and antler handles drilled to receive the tang of a tool of this type have been recovered from Kaymakç1. A vertically drilled example (93.545.118.84) is like a handle known from level VIIb at Troy, found still attached to a large awl. ${ }^{54}$ Another has a shallow rectangular hole in one end and could have held a similar but smaller kind of tool (99.526.65.7; see online fig. 12, no. 5).

Other examples of bone tools include a variety of items, such as sharp and blunt pointed objects (see online fig. 12, no. 6) that display some degree of working and use wear such as polishing and indentations.

\footnotetext{
${ }^{53}$ Schaeffer 1952, 43, figs. 3, 25; Deshayes 1960, 103, nos. 998-1000, pls. 12, 20.7; Catling 1964, 95, pl. 10.1; Bass 1967, 100, no. 131, figs. 112, 113 (still attached to a wooden handle); Müller-Karpe 1994, 168, pl. 72, nos. 49, 50: "chisel type 10"; Yalçın et al. 2005, 631, fig. 193.

${ }^{54}$ Blegen et al. 1958, 149-51, pl.254, no. 37-494. Two similar awls attached to bone handles date to EBA Troy (Hänsel 2014, 179, nos. Sch 6233, 6234, pl.9, nos. 18, 19).
} 

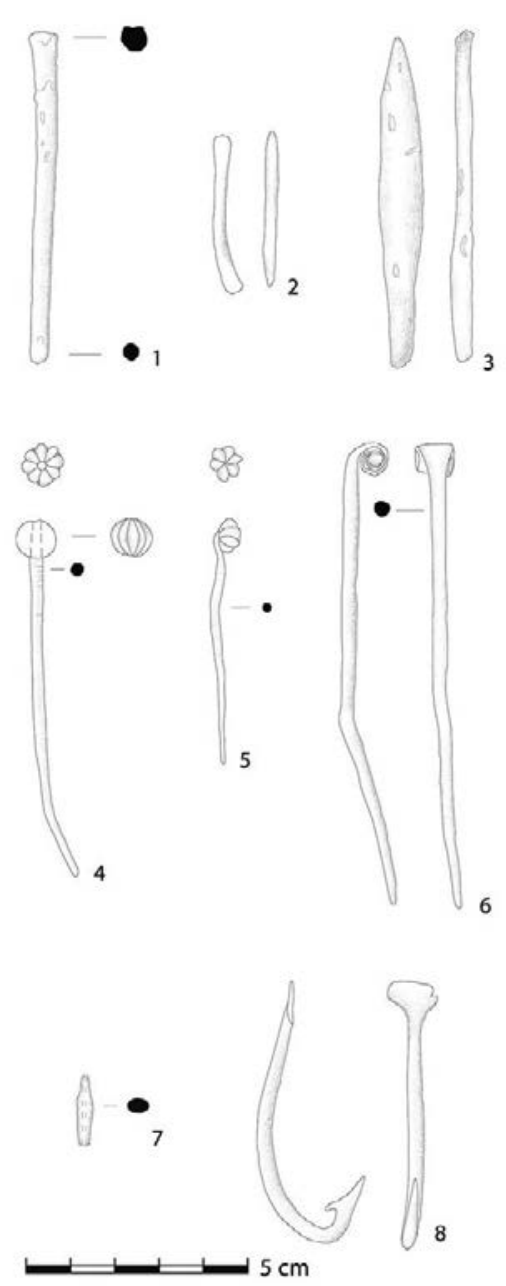

FIG. 20. Assorted tools and items of adornment from Kaymakçı (all bronze except 7): 1, punch (108.522.7.9); 2, punch with chisel-shaped heads (98.531.23.6); 3, leaf-shaped chisel (99.526.185.1); 4, 5, pins with melon-shaped head (93.545.10.1, 108.522.39.9); 6, pin with rolled head (109.523.41.1); 7 , faience bead (99.526.451.1); 8, hook (97.541.109.1) (drawings by E. Kiras; (C Gygaia Projects).

Two examples of tubular items from large mammal bones have been recorded as well as several examples of spatula-like objects, generally made from ribs, with a rounded edge and rounded point with evidence for use wear. A handful of crude scrapers, mostly from large mammal bones, have rounded, flattened (and occasionally polished) surfaces. ${ }^{55}$ Other crudely worked tools made of long-bone shaft fragments are tentatively interpreted as gorges, a type of fishing hook. These ob-

\footnotetext{
${ }^{55}$ For material from Troy and other sites, see Blegen et al. 1953, pls. 301-3; 1958, pls. 219, 255.
}

long items are made from half shafts of sheep or goat limb bones, with at least one pointed end, the other end either pointed or rounded. Each has an off-center notch made near the middle of its long side. ${ }^{56}$

Other items used in local productive activities such as polishing and pounding include rare conical tools made of reused sherds and much more common stone tools. Stone pounding tools were used to crush and grind various materials, including food. Some of these tools bear the sheen of polish, indicating their use in smoothing surfaces. Similarly, a local lithic industry of flaked tools is well attested by finds from Kaymakçı; these tools are still under study.

\section{Items of Adornment}

Clear evidence from Kaymakçı attests local production of ceramics, textiles, and other objects, yet it remains uncertain whether some finished products, such as jewelry and other items of adornment, were locally made or imported from elsewhere. Here we treat finished products such as pins, rings, beads, buttons, or pendants (see figs. 20, nos. 4-7; 21). Bronze pins at Kaymakçı have good parallels from inland western and central Anatolia. Most closely datable are two pins with melon-shaped heads (93.545.10.1, 108.522.39.9; see fig. 20, nos. 4, 5), as found in levels V-III at Hattusa (Lamellenkopfnadeln), IVb-II at Beycesultan, ${ }^{57}$ and at other Anatolian sites. ${ }^{58}$ Each has a long tapering shaft, and at least one is a composite pin with separately produced head. The head of this pin (see fig. 20, no. 4) has a centrally located hole for the seating of the shaft and is rounded, with eight vertical ribs that give it a star-shaped section. A rare example of a plate-headed pin (93.545.150.1) also has comparanda from Hattusa. ${ }^{59}$ The example from Kaymakçı most probably had

\footnotetext{
${ }^{56}$ Gorge-like bipoints were found in upper Mesolithic levels in the Cave of Cyclops on Youra; notched examples are known from EBA Poliochni on Lemnos (Moundrea-Agrafioti 2003, 138).

${ }^{57}$ Close parallels were found at Hattusa, in level III and in unstratified contexts of the lower town (Boehmer 1972, no. 489, pl. 22; also no. 572, pl. 24; 1979, nos. 2958-61, pl. 13), and in levels IV and III at Beycesultan (Mellaart and Murray 1995, nos. 23, 26, 51, 59).

${ }^{58}$ E.g., from Hittite-period stratum IV at Alişar Höyük (von der Osten 1937, 253, figs. 257, 259, esp. fig. 259, e 1537).

${ }^{59}$ Level III: Boehmer 1972, no. 515. Note also examples called toggle pins from the lower town at Hattusa (Boehmer 1979, nos. 3082-83). Such pins were found also in Hittite-period stratum IV at Alişar Höyük (von der Osten 1937, fig. 283).
} 


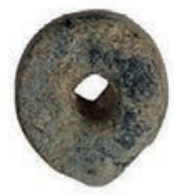

1

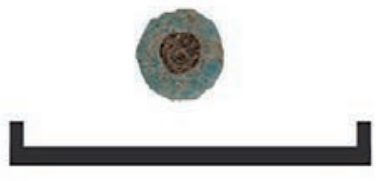

5

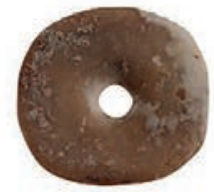

2

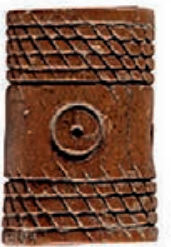

6

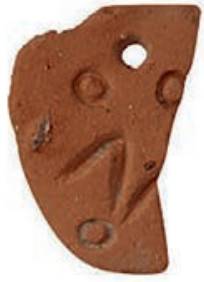

3

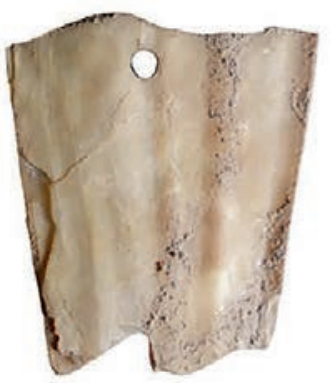

7

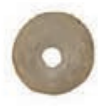

4

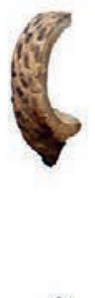

8

FIG. 21. Selection of items of adornment from Kaymakçı: 1, 2, stone pendants (99.526.318.1, 99.526.318.1); 3, clay pendant (93.545.276.1); 4, calcite bead (108.522.18.10); 5, faience bead (97.541.202.58; scale bar $=1$ $\mathrm{cm})$; 6, antler item (95.555.137.1); 7, shell pendant (93.545.301.1); 8, shell ring (97.541.56.17) (N. Gail; (C) Gygaia Projects).

a rhomboid head with a central hole of about $0.2 \mathrm{~cm}$ in diameter. Other types include widespread Bronze Age pins with simple spherical heads (99.526.297.8, 109.523.4.14) and at least three pins with rolled heads, with single (109.523.41.1; see fig. 20, no. 6) as well as double antithetical rolls $(81.551 .31 .11,97.541 .241 .1)$. Pins with single rolls are more widespread than those with double rolls, and both types are known from the MBA cemetery at Gordion, MBA levels at Tarsus, and from Early Bronze Age (EBA) levels at Troy. ${ }^{60}$

Metal rings from Kaymakçı in bronze and lead have parallels from Troy, Beycesultan, and Hattusa, as well as elsewhere in second-millennium B.C.E. Anatolia. Bronze rings are rare, but one mold-made example warrants mention. With an exterior diameter of about $1.6 \mathrm{~cm}$ and $0.3 \mathrm{~cm}$ wire thickness (97.541.13.1), it is too small to be a finger ring but may have served some other ornamental or functional use. ${ }^{61}$ More common

\footnotetext{
${ }^{60}$ Schmidt 1902, nos. 6399-402; Goldman 1956, 285, 295, pl. 431, nos. 207-9; Mellink 1956, 32, pls. 18b-d, 19j; Schalk 2008, nos. 305-7.

${ }^{61}$ Stone molds for similar but larger rings are known from
}

are 20 lead rings of varying size $(0.6-3.0 \mathrm{~cm})$ and weight $(0.2-8.5 \mathrm{~g})$, some with overlapping ends, recovered from a variety of contexts across the site (online fig. 13). Similar examples are known from the MBA cemetery at Gordion, where contexts suggest use as pendants, and in MBA and LBA Hattusa and Alişar Höyük, where they were found linked in chains; other examples are from MBA Liman Tepe, Aphrodisias, Tarsus; MBA-LBA Troy; ${ }^{62}$ and elsewhere in Anatolia. ${ }^{63}$

Other items of personal adornment include beads, pendants, and possibly also ornamental handles (see fig. 21, nos. 1-4). Several small pendants of schist, bone, limestone, marble, and clay, as well as clay beads,

Troy VIIa and various other Anatolian Bronze Age sites (Müller-Karpe 1994, 212-15, pls. 51-3; Pavúk and Pieniążek 2016, fig. 15).

${ }^{62}$ von der Osten 1937, 264, fig. 271; Goldman 1956, 302, pl. 435, nos. 6a-c; Mellink 1956, 35-6, pl. 20h-m; Boehmer 1972, 165-66, pl. 10, no. 1725 (period IVd), table 59; pl. 59, no. 1728 (period IVd-c); Joukowsky 1986, 672, no. 623.1, figs. 483.45, 484.26; Pieniążek 2015, 882-83; Erkanal et al. 2016, 327.

${ }^{63}$ E.g., the Hittite period in Alişar Höyük (stratum IV; Schmidt 1932, 268, fig. 258). 
likely represent local products, while faience beads were probably imported. Discoid, teardrop-shaped, and rectangular pendants in schist and limestone belong to the first group $(98.531 .16 .7,99.526 .318 .1$; see fig. 21, nos. 1,2). Among a variety of beads, a flattened, spherical calcite or alabaster bead of $0.9 \mathrm{~cm}$ diameter deserves individual mention (108.522.18.10; see fig. 21 , no. 4 ). Such calcite beads are very rare in the Aegean and Anatolia. ${ }^{64}$

A total of 15 miniscule, flat, circular beads most probably in faience (or frit) belong to one of the most widespread bead types of the eastern Mediterranean, well represented also in western Anatolian contexts. ${ }^{65}$ On average they measure $0.2 \mathrm{~cm}$ in diameter, approximately $0.1-0.2 \mathrm{~cm}$ in height, and have a centrally placed $0.1 \mathrm{~cm}$ vertical hole. The surfaces of all but one light blue-turquoise (vitreous) example (97.541.202.58, see fig. 21, no. 5) are very worn, showing only the brown to white faience core. Additionally, a relatively large and biconical bead (99.526.451.1; see fig. 20, no. 7), about $1.6 \mathrm{~cm}$ in length and $0.5 \mathrm{~cm}$ at maximum diameter, represents a type common in the second-millennium B.C.E. ${ }^{66}$ Beads like these may have been used in diverse ways in necklaces and bracelets, if not also as pinheads; the tiny faience beads may be textile appliqués. ${ }^{67}$

A final group of adornments includes decorated objects made of bone, antler, or shell. Two pieces of antler were cut to small cylindrical shapes measuring about $2.8-4.0 \mathrm{~cm}$ long and $1.6-1.8 \mathrm{~cm}$ in diameter (95.555.137.1, see fig. 21, no. 6; 99.526.11.22). One is incised with circles and crosshatched designs and the other only with circles. Both are perforated transversely as well as axially through the cylinder, the holes at both ends perhaps intended for rivets or other kinds

\footnotetext{
${ }^{64}$ An opaque calcite crystal was recovered from LBA Troy (Pieniążek 2012a, 213-14, fig. 16) and another perfectly transparent one from Kaymakçı (97.541.205.5).

${ }^{65}$ More than 70,000 were found at Uluburun, most in ceramic vessels (Ingram 2005, 19-25; Yalçın et al. 2005, figs. 968). Examples from western Anatolia include those from Troy (VI Early to VIIa; Pieniążek 2012b, figs. 1, 10) and Panaztepe (Çınardalı-Karaaslan 2012, fig. 3).

${ }^{66}$ Biconical faience beads are well known from Troy and Beşik-Tepe (Basedow 2000, 136-37, pls. 87, 88; Pieniążek 2015,875 ) as well as Panaztepe (Çınardalı-Karaaslan 2012, figs. 2-6).

${ }^{67}$ See, e.g., Hughes-Brock 1999, 282; Pieniążek 2016, 134-35.
}

of attachments. ${ }^{68}$ Other items interpreted as ornaments are perforated worked shells, including Conus mediterraneus and Unio sp., perhaps used as beads or pendants. Two objects from shell stand out. The first of these is a flat, trapezoidal object made from a Pinna sp. shell with a hole in the upper margin (see fig. 21, no. 7). ${ }^{69}$ The second is a fragment of Monodonta sp. shell with rounded, polished edges, similar examples of which found elsewhere in the Aegean and Cypriot Late Bronze Age are interpreted as rings (see fig. 21, no. 8$).^{70}$

\section{Miscellaneous Items}

As with items of adornment, for many other items it is presently difficult to determine the place of manufacture, but it is likely that many were locally made. Such items point to resource areas and convey information about the range of activities and interests of local communities. These include practices of exchange, game play, and perhaps also interest in the divine.

Two bronze knives and at least three whetstones have been recovered from Kaymakçı to date. Of the knives, a very rare example is a complete and well-preserved leaf-shaped blade with a square-faceted handle and incised herringbone decoration that terminates in ribbing and a rounded, rectangular knob (81.551.34.7, fig. 22, no. 1). Its form resembles a Sandars Class 4 knife. The closest examples come from contexts in mainland Greece, Crete, and Troy that date to the 14th or 13th century B.C.E..$^{71}$ The few known comparable Aegean knives have been found almost exclusively in elite graves (e.g., in chamber tombs at Mycenae) or cultic contexts (e.g., in the Psychro Cave on Crete and the Terrace House at Troy).

\footnotetext{
${ }^{68}$ Parallels for these designs are known from Troy VI Late (a crosshatched cylindrical seal; Blegen et al. 1953, 298, no. 35478, pls. 296, 304) and Beycesultan III (a "cheek piece" with circle motifs; Mellaart and Murray 1995, nos. 309-10, pl. O, nos. 36, 37). Bone items with similar decorations are known from Hattusa (Boehmer 1972, nos. 1981-85, 1991-2001, pls. $70,71)$ and tubular handle-like items in bone from Beycesultan (Mellaart and Murray 1995, nos. 324, 325, pl. O, nos. 38, 40, layers II-I) and Hattusa (Boehmer 1979, 46, nos. 3622, 3624, pl.28).

${ }^{69}$ Parallels for Unio sp. and Pinna sp. are known from Troy (Çakırlar 2009, 64, 66).

${ }^{70}$ Reese (1984) defines both Monodonta sp. rings as well as holed Conus mediterraneus shells as typical Late Mycenaean ornaments.

${ }^{71}$ Sandars 1955; Pieniążek and Aslan 2016, 423-24, pl. 123 b.
} 
The second knife (97.541.224.1, see fig. 22, no. 2) is an almost complete example of a sickle-shaped oneedged type with flangeless haft plate and single rivet hole for attachment to a wooden or bone handle. One of the most popular forms of knife in the region and known from many second-millennium B.C.E. contexts, it has parallels from, among other places, Troy, Hattusa, and mainland Greece. ${ }^{72}$

The three fragmentary whetstones recovered from Kaymakçı (e.g., 93.545.186.1, 97.541.412.1; see fig. 22 , nos. 3,4 ) were likely used to sharpen such bronze knives or other tools. All are produced from hard gray to black stone and all have drill holes at one end, likely used to attach the tool to a lanyard of sorts. ${ }^{73}$

Likely representative of community members' engagement in Aegean and eastern Mediterranean exchange opportunities are two small lead items found in surface contexts and interpreted to be balance weights based on comparison with examples known from contemporary second-millennium B.C.E. contexts. They are discoid in shape, one weighing $10.3 \mathrm{~g}$ and having smooth surfaces and irregularly finished edges (95.555.2.22, fig. 23, no. 1), the other weighing $9.1 \mathrm{~g}$ and having smooth surfaces and edges and a centrally located and unevenly applied, rough square punch on one side (97.541.31.1; see fig. 23, no. 2). Discoid balance weights of this type are known from many second-millennium B.C.E. Aegean contexts. Most come from the Cyclades (e.g., Akrotiri on Thera and Ayia Irini on Kea) and date to the beginning of the LBA (Late Cycladic I); other examples are known from elsewhere in the Aegean as well as from both earlier (Middle Minoan) and later LBA contexts (e.g., the 14th-century Uluburun shipwreck and 14th- to 13th-century B.C.E. Thebes). ${ }^{74}$ The weight of the items from Kaymakçı roughly conforms with standards

\footnotetext{
${ }^{72}$ For Troy, see Schmidt 1902, 256, nos. 6454-57; Blegen et al. 1958, 240, pl. 254, no. 36-398; Hänsel 2014, 133, pl. 4, 13-15 (all probably LBA, Troy VI and VII). For Aegean examples, see Sandars 1955, Class 6; Buchholz and Karageorghis 1971, 54, fig. 23, 642-45 (Late Minoan / Late Helladic III).

${ }^{73}$ For comparison from Troy VI and VIIa, see Blegen et al. 1953, pl. 299; 1958, pl. 220.

${ }^{74}$ Petruso 1978; Michailidou 1990; Pulak 1996; Aravantinos and Alberti 2006. Four lead weights, three of them discoid, are known from Hattusa (Boehmer 1972, 165, nos. 1721-24). For an inscribed rectangular example from Panaztepe, see ErkanalÖktü (2006, fig. on 20).
}

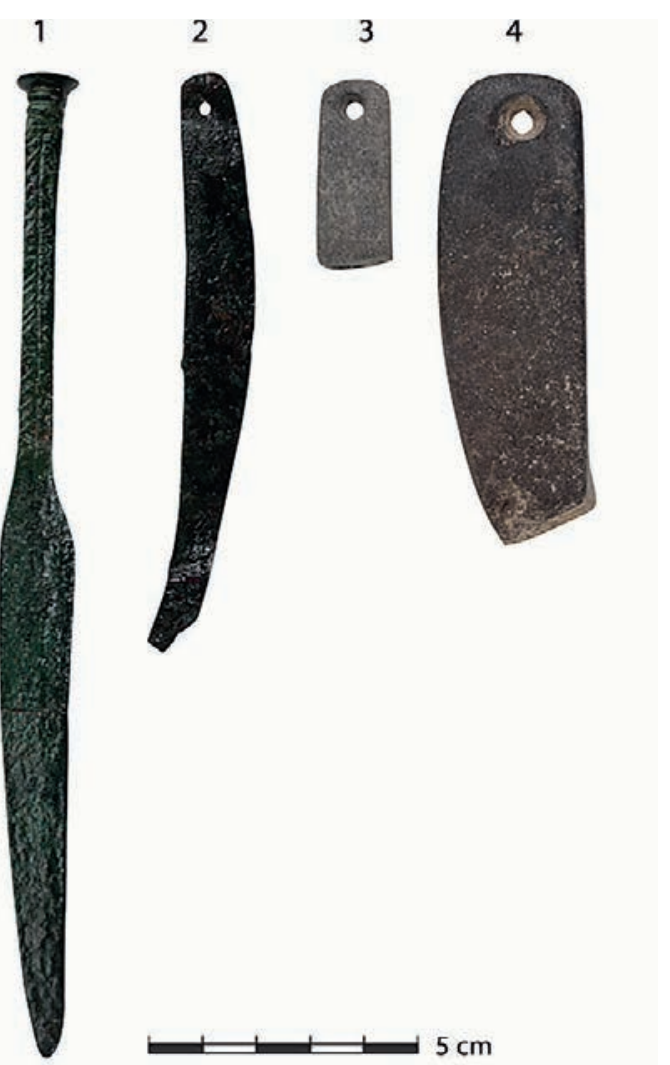

FIG. 22. Selection of knives and whetstones from Kaymakç1: 1, 2, knives (81.551.34.7, 97.541.224.1); 3, 4, whetstones (93.545.186.1, 97.541.412.1) (N. Gail; (C Gygaia Projects).

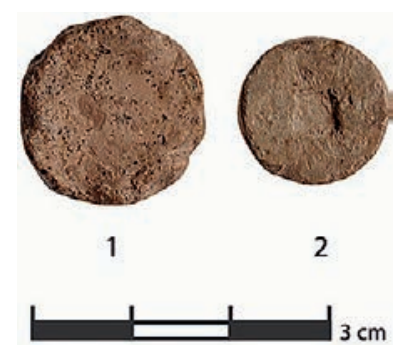

FIG. 23. Lead balance weights from Kaymakçı (1, 95.555.2.22; 2, 97.541.31.1) (N. Gail; (C) Gygaia Projects).

known from the eastern Mediterranean (ca. 9-10 g) and the lightest of Aegean lead weights (ca. $10 \mathrm{~g}$ ).

Interesting but functionally obscure items include a dome-shaped and vertically perforated lead object (99.526.246.1). It is heavier than the lead weights, at $19.0 \mathrm{~g}$, and may be a variation on a spindle whorl. The object has smooth surfaces and a central perforation of 
approximately $1.8 \mathrm{~cm}$ diameter at the peak of the dome that tapers toward the bottom. Additionally, the function of at least 27 small, discoid, ceramic items referred to as tokens is obscure (online fig. 14); they are like simple rounded sherds but are more carefully made, with small, regular sizes (1.5-2 cm in diameter), carefully finished edges, and simple rounded impressions and/or incised cross or star decoration. Noteworthy also are examples of worked astragaloi, or knucklebones, perhaps used in divination or gaming. ${ }^{75}$

Finally, several items have been fashioned into recognizable human or animal forms. Two small decorated objects resemble roughly anthropomorphic figurines or idols: a pear-shaped example in bone (97.541.197.1) and a small marble example with incised features (99.526.73.7, fig. 24, no. 1). ${ }^{76}$ Exceptional are figural sculptures in low-fired clay: one example from an LB 1 deposit measures 16 x $12.6 \mathrm{x}$ $11.5 \mathrm{~cm}$ and vaguely resembles the muzzle and foreparts of the head of a bull, with roughly symmetrical nostril and eye depressions (99.526.335.1); its smooth bottom surface suggests it was made to lie flat or perhaps hang from a wall. A few obscure horn-shaped ceramic fragments have been found at Kaymakçı as well. One is faceted smoothly and perforated transversely at one end (97.541.34.1; see fig. 24, no. 2). Similarly, several terracotta pieces belonging to animal figurines or rhyta have been found, including what appears to be a bull's leg (108.522.11.25; see fig. 24, no. 3), with parallels known from many Aegean and western Anatolian sites. ${ }^{77}$

\section{SUBSISTENCE ECONOMIES}

Activities associated with subsistence were also key components of daily life at Kaymakçı. Much of the artifactual evidence in bronze, bone, and stone mentioned above speaks to industries related to subsistence. Implements associated with textile production may relate to ovicaprid husbandry practices focused on

\footnotetext{
${ }^{75}$ For astragaloi and modified astragaloi from Bronze and Iron Age Gordion, see Dandoy 2006. Greaves (2013) discusses artificial astragaloi likely used in divination by lot at Iron Age Ephesus and mentions a modified example from Kinet Höyük. At least one example from Kaymakçı displays smoothing, as do those from Bronze Age Gordion.

${ }^{76}$ For good parallels from Troy VIIh, see Blegen et al. 1958, pl. 254, no. 37-501.

${ }^{77}$ For the bull rhyton from Troy, see Rigter and ThummDoğrayan 2014; Pieniążek and Aslan 2016, 424.
}

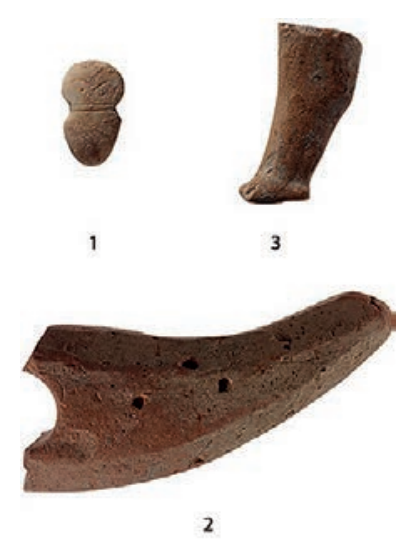

FIG. 24. Figural objects from Kaymakçı: 1, marble "idol" (99.526.73.7); 2, horn made of clay (99.526.73.7); 3, clay bull's leg (97.541.34.1; probably a fragment of a bull rhyton or figurine) (N. Gail; (C) Gygaia Projects).

wool or fleece production. Basalt and diorite grinding stones of varying size and type suggest cereal processing (e.g., 98.531.6.162). Examples from Kaymakçı are of types well known in western Anatolia and the Aegean, including elliptical to ovate saddle querns and elliptical handstones. ${ }^{78}$ Rounded quartzite and limestone pounders may have served food processing or preparation needs, and the semi-subterranean circular features found in several areas of the site likely served as grain silos (see below). More than any worked artifact or feature, however, botanical and faunal evidence most directly reflect subsistence economies and local strategies of agropastoral management and production.

\section{Methods and Preservation}

Botanical and faunal remains were collected from all excavated contexts, with large faunal remains and charcoal fragments recovered by hand or dry sieving in the field and smaller faunal and botanical remains sampled systematically through flotation of approximately 10-liter sediment samples from each excavated context. ${ }^{79}$ Laboratory analyses of archaeobotanical remains involved sorting and identification of plant remains by taxon, which are quantified by count and weight. Faunal analyses recorded standard primary

\footnotetext{
${ }^{78}$ Kardulias and Runnels 1995, 112-21, figs. 94, 95.

${ }^{79} \mathrm{KAP}$ collection strategies followed previously established and standardized protocols. See Reitz and Wing 2008, 146-51; d’Alpoim Guedes and Spengler 2014; and Pearsall 2015.
} 
data: count, weight, taxon, element, age at death, sex, biometrics, nonmetric traits, and taphonomic modifications, including butchery.

Given soil conditions and the near-surface nature of the latest preserved contexts at Kaymakçı, the state of botanical and faunal preservation varies with depth. Thick calcium carbonate accretions cover most faunal samples, obscuring the visibility of taphonomic agents, butchery marks, and traces of pathologies, while botanical remains from shallow, near-surface contexts show evidence of substantial bioturbation, including the presence of modern, uncarbonized plant remains, especially rootlets but also seeds, as well as insect parts and rodent feces. Preservation of bone and carbonized seeds improves with stratigraphic depth.

\section{Botanical Remains}

Archaeobotanical processing included flotation of 653 bulk sediment samples, from which small quantities of sediment were reserved for future microbotanical (phytolith and starch) analyses, and hand selection of 70 charcoal samples. Analysis of archaeobotanical remains from 263 flotation samples to date reveals a diversity of crop plants that reflect local agricultural production. Cereals include barley (Hordeum vulgare), free-threshing wheat (Triticum aestivum/durum), emmer wheat (Triticum turgidum spp. dicoccum), and einkorn wheat (Triticum monococcum); legumes include bitter vetch (Vicia ervilia), chickpea (Cicer arietinum), lentil (Lens culinaris), and grass pea (Lathyrus sativus). Grape (Vitis vinifera) is the only fruit identified to date. This range of crops is common at other LBA sites in western and central Anatolia, including Troy and Gordion. ${ }^{80}$ Based on the relative frequency and ubiquity (i.e., the proportion of samples in which a taxon occurs) of these remains, the most common cultigens at Kaymakçı are barley, free-threshing wheat, bitter vetch, and chickpea, while grapes also appear to have been an important crop (table 1; online fig. 15).

Cereals comprise $32 \%$ of the Kaymakçı crop seed assemblage by count and $37 \%$ by weight, while pulses contribute $63 \%$ by count and $60 \%$ by weight, and grapes form a smaller component: $5 \%$ by count and $3 \%$ by weight. These proportions are skewed by the inclusion of two samples from 99.526 (contexts 497 and 572) that contain 146.5 and 111 bitter vetch seeds,

\footnotetext{
${ }^{80}$ Riehl 1999, 149-50; 2014; Miller 2010, 243; Pavúk et al. 2014; Marston 2017.
}

respectively. When these are excluded, the proportions of cereal and pulse by count are nearly equal, at $46 \%$ and $44 \%$, respectively, and grapes comprise $10 \%$ of the assemblage. These proportions fall in the mid range of published comparable sites, between the Aegean site of Troy, with a dominance of pulses, and KamanKalehöyük and Gordion, which lie on the central Anatolian plateau and are dominated by cereals (fig. 25). ${ }^{81}$ This pattern is observed generally between Aegean and Near Eastern sites, with a greater frequency of pulses in the Aegean region than in drier, inland areas of the Near East. ${ }^{82}$ Excluding crop stores, the proportion of grape seeds is much higher at Kaymakçı than at other contemporary sites on both the Aegean coast and the Anatolian plateau.

The use of fuel at Kaymakçı can also be assessed using botanical remains, which allow determination of the relative frequency of the use of wood versus dung as fuel, the latter being common among sites across the Near East. ${ }^{83}$ Charred density, a standardized measure of burning intensity, and the wild seed to charcoal ratio among fuel-residue deposits provide measures of the types and amounts of fuel used at a site. ${ }^{84}$ Neither charred densities nor wild seed to charcoal ratios are possible to calculate from Kaman-Kalehöyük or Troy, as the quantity of wood charcoal is not recorded at either site. Comparing Kaymakçı to Gordion and contemporary levels of the site of Umm el-Marra in Syria, however, is informative (table 2).

The wild seed to charcoal ratio of 15.5 at Kaymakçı is significantly lower than both Gordion and Umm el-Marra, indicating less reliance on dung as fuel; additionally, no charred dung pellets - typically common in dung-burning assemblages - have yet been identified. ${ }^{85}$ That charred densities are significantly lower at Kaymakçı is likely an effect of poor preservation of near-surface botanical deposits. Future study of wood charcoal from Kaymakçı may reveal that woody

\footnotetext{
${ }^{81}$ Data from Troy comprise all VIIa samples (Riehl 1999; $\mathrm{n}=19$ ), from Kaman-Kalehöyük all LBA samples (Üstünkaya 2015; n=15), and from Gordion all Yassıhöyük Stratigraphic Sequence 9/8 samples (Marston 2017; n=32).

${ }^{82}$ Riehl and Nesbitt 2003, 305-6.

${ }^{83}$ For ruminant dung used as fuel, see Miller 1984. Primary archaeobotanical methods of identifying dung fuel center on the seed to charcoal ratio or its derivative, the wild seed to charcoal ratio, used here (Miller and Marston 2012; Marston 2014).

${ }^{84}$ Marston 2014.

${ }^{85}$ Miller 1984.
} 
TABLE 1. Count, weight, and ubiquity of cultivated plant species, Cyperaceae, total wild seeds, and wood charcoal $>2 \mathrm{~mm}$ from 263 flotation samples.

\begin{tabular}{lccc}
\hline & Count & Weight (g) & Ubiquity \\
\hline Cereal & & & \\
Barley (Hordeum vulgare) & 104 & 1.223 & 0.183 \\
Free-threshing wheat (Triticum aestivum/durum) & 28 & 0.341 & 0.080 \\
Einkorn wheat (Triticum monococcum) & 11 & 0.056 & 0.046 \\
Emmer wheat (Triticum turgidum sbsp. dicoccum) & 4 & 0.057 & 0.023 \\
Wheat (indeterminate; Triticum sp.) & 12 & 0.155 & 0.084 \\
Cereal (indeterminate) & 56 & 3.272 & 0.494 \\
Pulses & & & \\
Chickpea (Cicer arietinum) & 49.5 & 1.861 & 0.099 \\
Grass pea (Lathyrus sp.) & 1 & 0.008 & 0.008 \\
Lentil (Lens culinaris) & 4.5 & 0.071 & 0.027 \\
Bitter vetch (Vicia ervilia) & 353 & 5.128 & 0.213 \\
Pulse (indeterminate) & 13.5 & 1.227 & 0.270 \\
Fruit & & & \\
Grape (Vitis vinifera) & 35 & 0.383 & 0.230 \\
Wild seeds & & & \\
Sedge (Cyperaceae) & 117 & - & 0.183 \\
Total count (including Cyperaceae) & 604 & - & 0.540 \\
Wood charcoal & - & 38.977 & 0.536 \\
\hline
\end{tabular}

trees and shrubs made up the primary fuel on site. Preliminary examination indicates most is oak, possibly evergreen Quercus coccifera, which dominates the local landscape of the Marmara Lake basin today. Greater understanding of forest cover will shed light on the botanical landscape of animal husbandry practices as well.

\section{Faunal Remains}

Preliminary archaeozoological processing included analysis of nearly 18,000 specimens derived from drysieved and hand-collected samples and additional material recovered from the heavy fraction of flotation samples (from which came most of the bird, reptile, and amphibian bones). Current results show a large taxonomic diversity, including the common Mediterranean domesticates of the Bronze Age; wild mammals such as deer (Cervus elaphus, Dama dama, Capreolus capreolus), boar (Sus scrofa), hare (Lepus europaeus), dog (Canis sp.), badger (Meles meles), and fox (Vulpes vulpes); freshwater fish such as cyprinids (the carp family) and silurids (the catfish family); as well as birds, rodents, reptiles, and amphibians (online figs. $16,17)$. Invertebrates are represented by various terrestrial, freshwater, and marine mollusks. Additionally, remains of at least one bear (Ursus arctos) and one large felid (possibly Lynx lynx or Panthera sp.) were recovered from deeply buried LB 1 contexts in 93.545 .

Among contemporary sites in the Aegean and Anatolia from which faunal evidence is published, the relative proportions of the most important taxa at Kaymakçı are most like those reported from LBA Kastanas, a settlement in a well-watered region of northern Greece (fig. 26) ${ }^{86}$ This similarity no doubt results from Kaymakçı's comparable situation in a well-watered local environment. Remains of domestic ruminants (cattle, sheep, and goats) are abundant, but the dominant taxon is pig (Sus scrofa/domesticus), which would have been at home in the marshlands

\footnotetext{
${ }^{86}$ Becker 1986.
} 


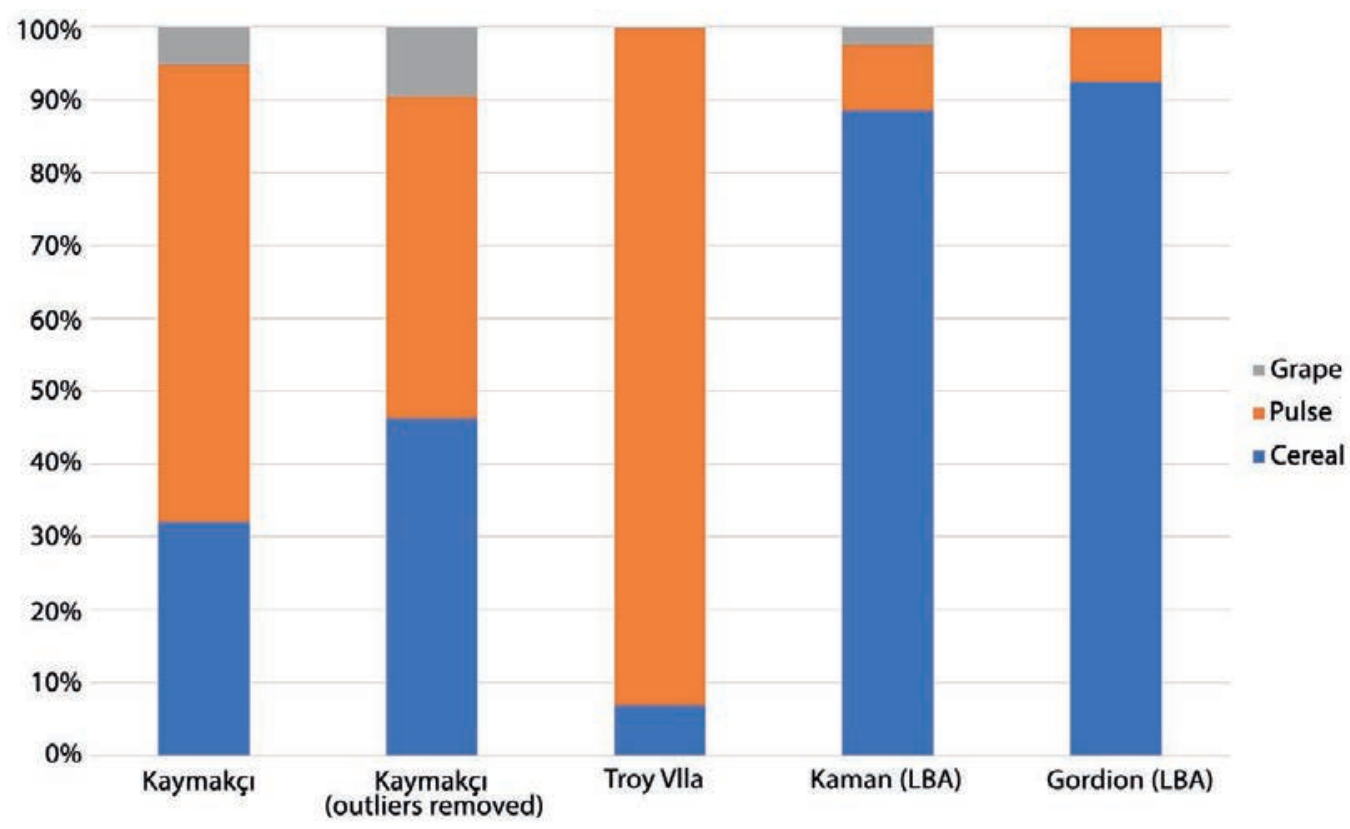

FIG. 25. Relative proportions of identified cereal and pulse seeds (excluding indeterminate remains) from Kaymakçı and contemporary levels of Troy, Kaman-Kalehöyük, and Gordion.

TABLE 2. Cereal to pulse ratios (grams/grams for Kaymakçı and Gordion; grams/50 count for Umm el-Marra), charred density (grams/liter), and wild seed to charcoal ratios (count/grams) for Kaymakçı and comparative sites with evidence for extensive dung fuel use.

\begin{tabular}{lccc}
\hline & Kaymakçı & Gordion (LBA) & Umm el-Marra (LBA) \\
\hline Cereal:pulse $(\mathrm{g} / \mathrm{g}, \mathrm{g} / 50 \mathrm{ct})$ & 0.63 & 14.57 & 11.25 \\
Charred density $(\mathrm{g} / \mathrm{l})$ & 0.022 & 0.701 & 0.760 \\
Wild seed:charcoal $(\# / \mathrm{g})$ & 15.5 & 28.5 & 30.0 \\
\hline
\end{tabular}

Note: The data are taken from Marston 2017 (Gordion); Schwartz et al. 2000, 443 (Umm el-Marra).

and oak forest surrounding the settlement. Deer, too, is abundant, especially fallow deer (Dama dama), which would have thrived in the riverine/lacustrine landscape. The aquatic environment was also exploited for substantial amounts of small and large carp and catfish. The large proportion of fish remains relative to contemporary sites in Anatolia and Greece may be a product of the project's intensive dry-sieving and flotation program. Also of note is the one rare barbed fishing hook in bronze (97.541.109.1; see fig. 20, no. 8). ${ }^{87}$ The scarcity of bronze fishing hooks may relate to

\footnotetext{
${ }^{87}$ The use of barbed hooks with shanks terminating in plates spans at least the EBA to the Iron Age (e.g., Buchholz et al. 1973,
}

the abundance of bone gorges, notched implements indicative of a local fishing industry (see above). Despite systematic sieving and flotation, the relatively small proportion of bird bones is notable, especially given Lake Marmara's status as an important bird area today.

The relative proportion of cattle at Kaymakçı is quite low compared, for example, with LBA levels at Hattusa (Boğazköy). ${ }^{88}$ Cattle would have been well suited to grazing the well-watered environment, but

170-74, fig. 55). The plate on the Kaymakçı example is not perforated, which is similar to a smaller example from EBA Troy (Hänsel 2014, 141, no. Sch 6708, pl. 11, 21). Barbed hooks are also known from Uluburun (Yalçın et al. 2005, 628, fig. 184).

${ }^{88}$ von den Driesch and Pöllath 2004. 


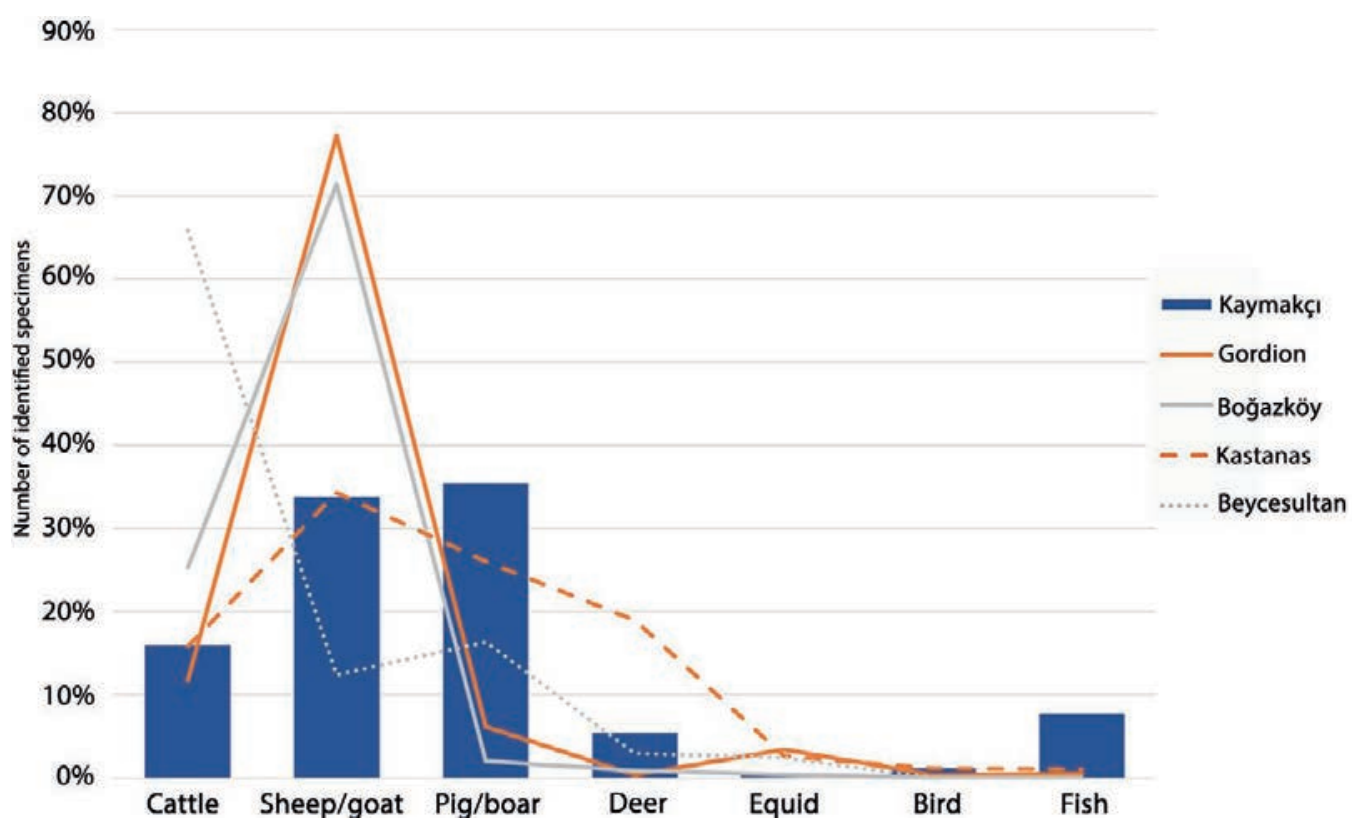

FIG. 26. Number of identified specimens of major taxa at Kaymakçı compared with selected published LBA assemblages in Anatolia and Greece. The data are taken from Ducos 1965; Becker 1986; von den Driesch and Pöllath 2004; Miller et al. 2009.

ill suited to stalling and slaughtering within the citadel of Kaymakçı, given their size and the restricted space, steep sides, and elevation of the citadel. Their relatively low proportion, then, might reflect off-settlement carcass processing rather than an unimportant role in local subsistence practices. A more likely explanation for the apparent low proportion of cattle in the assemblage is the relatively high proportion of pigs, an abundant source of protein.

Mortality profiles indicate the exploitation types and economic importance of animals by comparing population characteristics to known profiles of wild versus domestic herds, thereby shedding light on culling choices made in herd management. The survivorship data for sheep and goats from Kaymakçı (fig. 27) indicate that $20-30 \%$ of the herd was kept until very old age- - beyond what is economically viable for meat exploitation and milk production or for maintaining herd size alone. These data suggest that producing and trading wool might have been economically important at Kaymakçı, contributing to a broader, regional economy based on the ownership of sheep and goat herds. A peak in the culling activity of one- to two-year-old sheep and goats (stage $\mathrm{D}$ in fig. 27) may relate to practices of culling for managing herd composition, seasonal needs, tender meat exploitation, or optimal meat gains. Finally, the presence of fetal and neonate bones of sheep and goats from within the citadel suggest that these animals were part of the urban landscape, rather than being provisioned from outside pastoralists.

The culling profile of pigs (Sus sp.) raises interesting questions about how pigs were exploited and for what purposes. Almost $30 \%$ of the pig population was culled at between six and 12 months of age (stages B and $\mathrm{C}$ in fig. 28). Culling activities are less clear for pigs over a year old, of which about $30 \%$ survive beyond four and a half years (stage $\mathrm{E}$ in fig. 28) and some even up to eight years or more. This mortality pattern can be contrasted, for example, with LBA data from Tell Atchana in southern Turkey ${ }^{89}$ There, most (70\%) of Sus sp. cullings took place before individuals reached one year of age, and all took place before two or two and a half years of age (stage E in fig. 28), when 30\% of the pig population at Kaymakçı was still alive. This pattern indicates intensive pig husbandry at Atchana under a penning or alternating herding and penning regime focused on meat exploitation. Culling patterns at Kaymakçı, more specifically the punctuated peaks of culling by six to 12 months of age and again well after

\footnotetext{
${ }^{89}$ Çakırlar et al. 2014.
} 


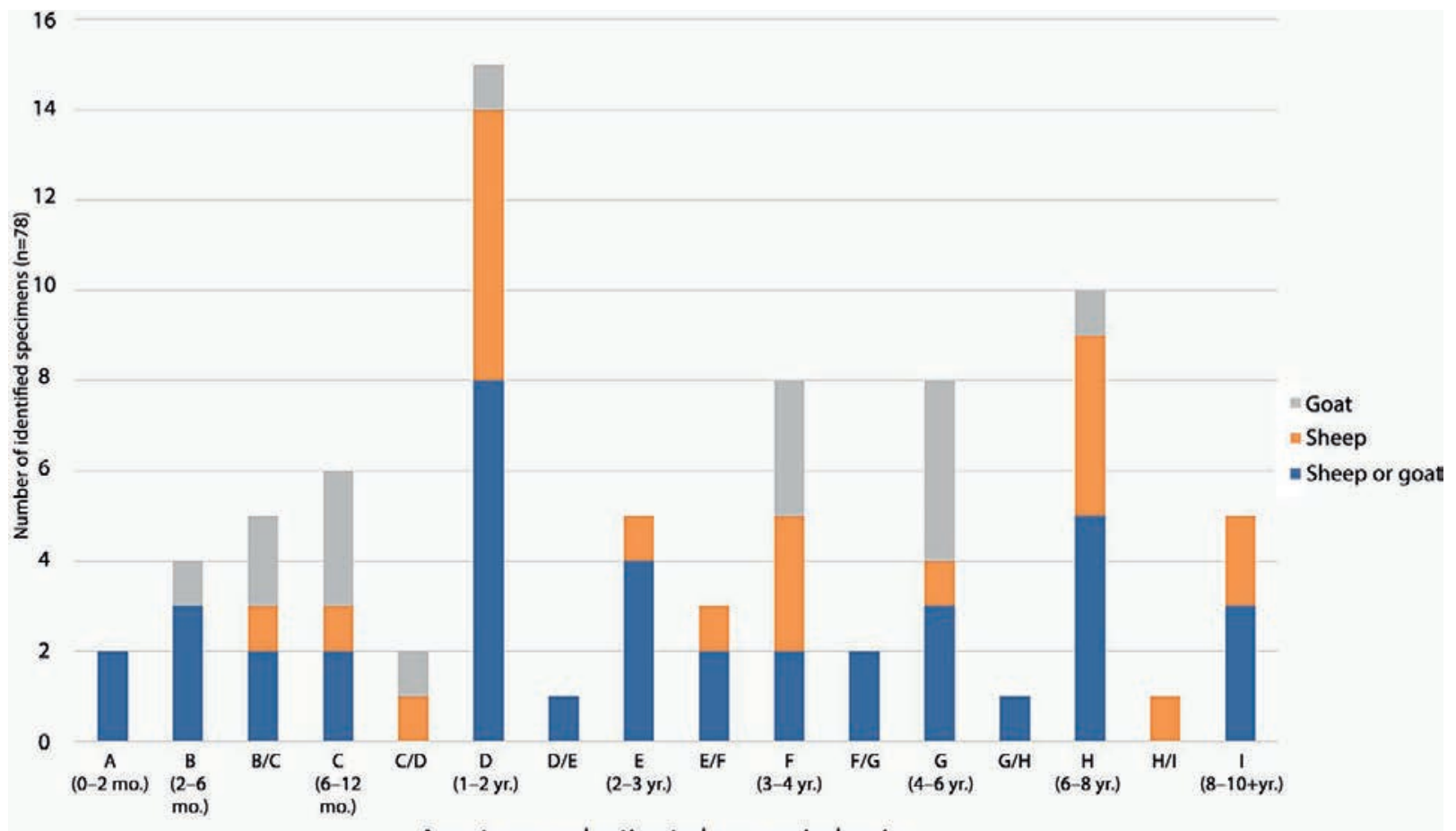

Age stages and estimated age equivalencies

FIG. 27. Culling profile of goats, sheep, and sheep or goats at Kaymakçı, based on mandibles with teeth recorded following Grant 1982. Age groups follow Zeder 2006. Age estimates follow the revised age groups in Zeder 2006, figs. 31, 32 ((c) Gygaia Projects).

pigs reached their optimal meat weight at two or two and a half years, suggest that, while pigs may have been kept close to the settlement, and perhaps even within the settlement in some seasons (fetal and newborn piglets make up 3\% of the pig assemblage), they likely were left to roam freely in the surrounding wetlands and oak forests most of the year and were slaughtered seasonally, possibly in relation to festivities. Further analyses will shed additional light on the nature and role of animal husbandry strategies at Kaymakçı..$^{90}$

\section{Preliminary Landscape Reconstruction}

This abundance of faunal and botanical evidence for subsistence economies at Kaymakçı reveals not only what strategies local communities employed to survive every day but also details concerning the landscapes in which they lived. The prevalence of oak identified in preliminary charcoal analysis, likely Quercus coccifera, which dominates the present landscape of this region, suggests that open woodlands covered the foothills around Kaymakçı; these would have been suitable for

\footnotetext{
${ }^{90}$ Cf. Ervynck et al. 2007; Lemoine et al. 2014.
}

grazing species well represented on-site, including both deer and pig or boar, and they would have provided abundant building material. ${ }^{91}$

The abundance of fish and freshwater bivalves also indicates a high resource dependency on aquatic environments. The specific species and diversity of sizes of fish from Kaymakçı further suggest they may derive from a lacustrine environment, providing evidence for the existence and proximity of Lake Marmara in the second millennium B.C.E. Catfish (Silurus glanis) up to $100 \mathrm{~cm}$ in total length were caught and brought to the site as whole carcasses. Furthermore, the presence of bulrush (Scirpus) seeds among the wild seed assemblage suggests that some economic crops were raised in a wet environment, ${ }^{92}$ whether due to intentional irrigation or lakeside farming in a tradition of annual fertileland reclamation. In sum, subsistence practices reflect an integrated system of landscape management, with a diversified system of farming, herding, and fish and game hunting, which produced a surplus that could

\footnotetext{
${ }^{91}$ Cf. Uerpmann 2003; Sykes 2014.

${ }^{92}$ Miller 1997; Riehl 2014.
} 


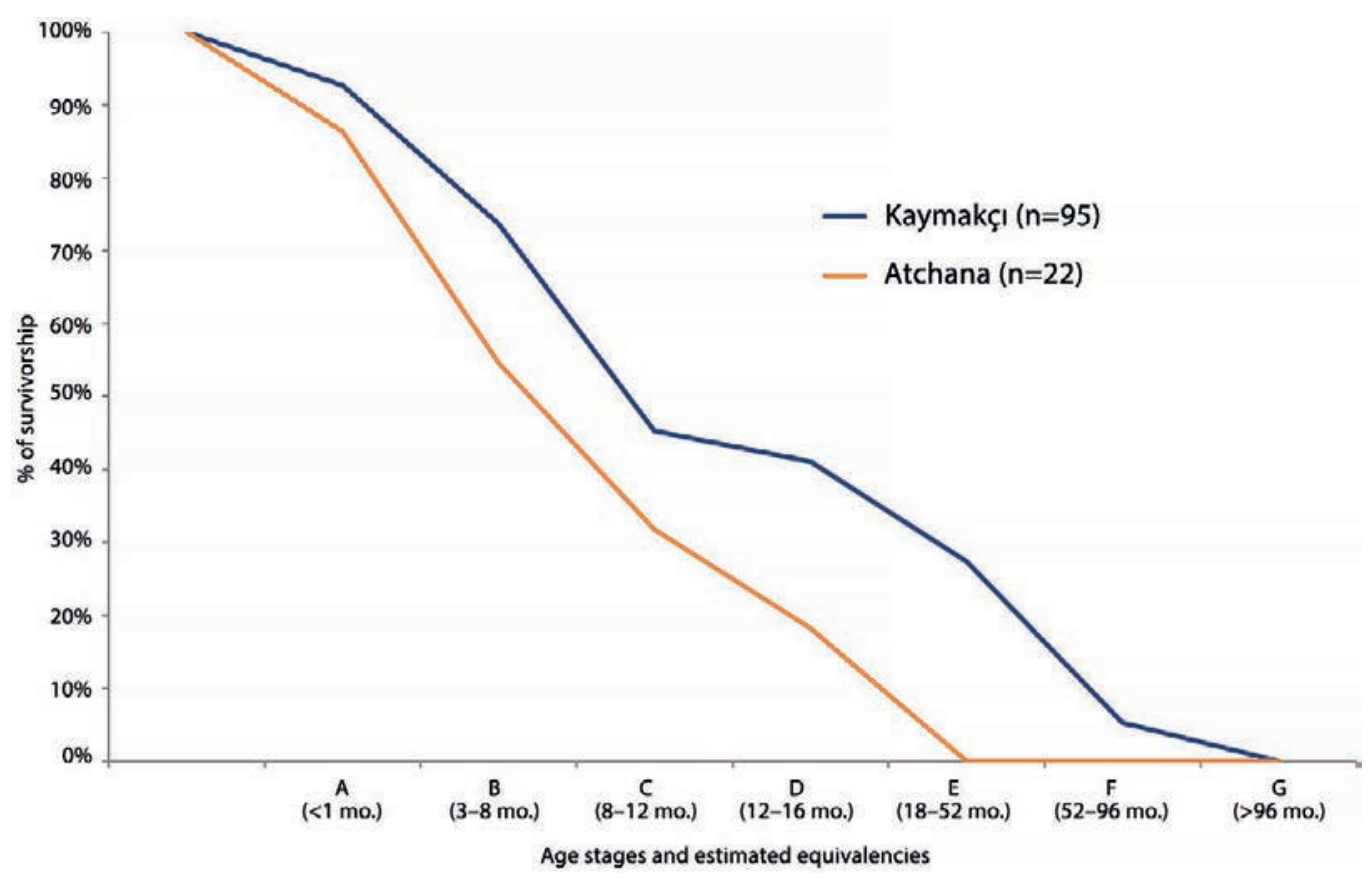

FIG. 28. Survivorship of Sus sp. (pig or wild boar) at Kaymakçı, based on mandibles with teeth recorded following Grant 1982, plotted against Atchana LB II, Area 4 (Çakırlar et al. 2014) for comparison. Age stages follow Lemoine et al. 2014, Simplified A system. Age estimates follow suggested age classes in Lemoine et al. 2014, table 7.

be stored in the facilities located within the most protected space at the site.

\section{DISCUSSION}

\section{Spatial Development}

The stratigraphy and finds described above provide a general picture of Kaymakçı's development. At the early end of Kaymakçı's period of occupation, the clearest evidence of MBA activities comes from beneath the street exposed in area 108.522. Even if the MBA sherds deriving from the street's sub-bedding were redeposited from elsewhere, they point to MBA activities in the southern terrace dating perhaps as early as the 21 st century B.C.E. Similarly, very early LBA (or MBA?) material and superimposed walls in area 93.545 of the inner citadel suggest that area, too, was in use early in the site's history.

Current evidence suggests the citadel fortifications were constructed initially in the LB 1 phase, with modifications over time. The formerly continuous trace of the curtain wall in area 95.555, for instance, was cut through for the installation of projecting towers and probably a gate. Elsewhere, too, the LB 1 phase marks the beginning of new uses of space. In the inner citadel, relative and radiometric dating of the circular features show that some date generally to LB 1 and others to LB 2 , while the building complexes of area 97.541 appear to date almost entirely to LB 2 , with a terminus post quem for their construction in the 15 th century B.C.E. The wide street of the southern terrace appears also to have been established early in LB 1 , while areas farther west, in area 99.526, were being used for open-air activities. The densely packed building complexes of the southern terrace appear to date to the LB 1 phase and remained in use through the LB 2 phase before abandonment. For this later phase of Kaymakç1's occupation, the two Mycenaean Ware sherds of the 14th/13th century B.C.E. from area 97.541 help date the latest architectural phase of the inner citadel. Yet distinctive sherds associated with the rubble collapse of the inner citadel wall in 93.545 may date the latest phases of activity to the very late LBA, or perhaps even the early EIA. Otherwise, no other evidence sheds light on the end of Bronze Age activities at the site, and there is no indication of widespread destruction.

\section{Spatial Organization}

With respect to the organization of activities across the citadel of Kaymakçı, it is important to note that most excavated contexts represent secondary or even 
tertiary fills rather than primary-use deposits. What is more, no excavation area shows exposed widespread conflagration or anything interpretable as a destruction level. ${ }^{93}$ Nonetheless, differences in architecture as well as artifact, faunal, and botanical assemblages speak to a diversity of activities.

Excavations along the fortification system reveal architecture suited best to defense, unsurprisingly, and relatively few activities associated with residential life and small-scale industrial production. The architecture in both 81.551 and 95.555 exhibits a monumentality not seen elsewhere on site, with a wide curtain wall and towerlike features. Both areas produced relatively many nonperforated rounded sherds and tokens but relatively few textile tools. Similarly, these areas revealed no hearths and contained only insignificant amounts of carbonized seed remains but relatively large amounts of charcoal. For instance, fortification areas produce an economic seed to charcoal ratio of 0.009 , compared with 0.427 and 0.562 in the inner citadel and southern terrace, respectively. The relative charcoal abundance indicates wood-burning activities for purposes yet to be determined.

The inner citadel produced evidence for more routine residential activities and a primary function most likely related to storage for at least the LB 1 and part of the LB 2 phase. Of the circular features so prominent in the inner citadel, none appeared to contain primaryuse contexts; all had been emptied and later filled in antiquity such that botanical evidence for their original use is absent. In the absence of other evidence, their function as grain silos is most probable based on their form, location, and resemblance to similar features at roughly contemporary sites in central Anatolia (e.g., Alaca Höyük, Kaman-Kalehöyük), western Anatolia (e.g., Troy VI Early/Middle, Çeşme-Bağlararası LBA Layer 0, MBA-LBA Liman Tepe III and II, Şarhöyük Phase 3), and the Aegean (e.g., Knossos, Malia, Protoand Neopalatial periods). ${ }^{94}$ In addition to storage, activities of spinning, eating, and hunting are indicated

\footnotetext{
${ }^{93}$ Contra Luke and Roosevelt 2009, 209.

${ }^{94}$ Fairbairn and Omura 2005; Erkanal 2008, 96; MangaloğluVotruba 2011, 44-6; Çınaroğlu and Çelik 2013, 201-2; Baştürk 2014; Pavúk 2014, 113-14, 153, 167, 330, 408-9, 432; Privitera 2014; Şahoğlu et al. 2014, 185; Kessler 2015; Erkanal and Aykurt 2017, 174; Thumm-Doğrayan et al. (forthcoming). Alternative (and non-mutually exclusive) interpretations see the circular features as "ritual pits," as described in Hittite texts (see Süel and Süel 2013, 187-91; Luke and Roosevelt 2017, 14).
}

by several large-diameter spindle whorls, a variety of ceramic forms, and the remains of bear and a large cat.

Within and around the building complexes of 97.541, cooking and other food processing activities are well represented. Among carbonized barley, wheat, bitter vetch, and grape seeds, relatively high concentrations of chickpea and free-threshing wheat were recovered. The concentration of chickpea from the alley between buildings in 97.541 suggests this space may have been used for refuse, with cooking occurring nearby. Grinding stones and butchery and bone waste in 97.541 reflect similar activities, including primary butchering of cattle. Otherwise, the faunal assemblage of the inner citadel suggests a higher frequency of processing or consumption of cattle, pigs, and deer than elsewhere on the site.

Like the inner citadel, area 98.531 on its southern slopes seems to have been used for mixed domestic and industrial purposes, with an emphasis on storage in pithoi yet less evidence for small crafting. This area produced more than two times as many pithos sherds by weight per square meter than others, with pithos installations and pithoi found in situ. Carbonized remains suggest a similar variety of crops, including barley, wheat, bitter vetch, and grapes.

The importance of food storage is evident on the southern terrace as well, but not yet to the same degree as in the inner citadel and on the surrounding slopes. The circular feature in 99.526 and the two poorly preserved examples in 108.522/109.523, all of the LB 2 phase, were again most likely used as grain silos, and pithos emplacements found near the latter support this hypothesis. Mixed domestic functions and household industries are attested by associated architecture and features as well as artifact, faunal, and botanical assemblages. House-like architecture separated by streets and alleys and assemblages replete with grinding stones, botanical remains, and bone refuse represent common domestic activities. Textile implements were common in these areas, too, while bronze tools from area $108.522 / 109.523$ point to further craft production.

Evidence for subsistence economies in the southern terrace shows patterns distinct from those of the inner citadel. The faunal assemblage from 99.526 in particular contains a larger proportion of small mammals and about double the number of fish compared with elsewhere in the site. Additionally, chopping and cutting marks on animal bones may reflect different culling techniques. A higher frequency of partial skeletons of piglets, goats, and sheep (99.526.573), varying from 
neonate to juvenile or subadult ages, as well as human fetuses (99.526.440 and 99.526.573) are notable, just as botanical remains are similarly distinctive.

High numbers of carbonized seeds from 99.526 show slightly higher proportions of bitter vetch and barley compared with the chickpea and bread wheat of the inner citadel. It should be noted as well that the combination of bitter vetch and barley is often associated with animal feed, as found in contexts interpreted as stables at Troy. ${ }^{95}$ Elsewhere and in other times, however, bitter vetch was used in medicinal treatments associated with skin irritations and even as an antidote for poison, though it can itself be toxic. ${ }^{96}$ Whether this particular crop combination was meant for regular use as animal feed or occasional use for human consumption at Kaymakçı is unclear.

\section{Interregional Interaction}

Materials recovered from Kaymakçı to date reflect a variety of raw materials (e.g., ceramic, terracotta, metal, stone), functions (e.g., residential, household production, industrial), and sources (local and imported). While many traditions of production were local, the evidence also reflects the connection of local communities to broader traditions and networks of exchange in the Aegean and Anatolia. Ceramic styles are most closely related to those of central western Anatolia and sites such as Panaztepe, Liman Tepe, and Bademgediği Tepe; sites in the Bakırçay valley; and sites farther afield such as Aphrodisias, Beycesultan, and Troy. The assemblage is dominated by local production with relatively few ceramic imports. Unlike in areas farther west and north, the abandonment of burnishing at an early stage of the LBA is distinctive to Kaymakç and is perhaps linked to the increased use of regionally characteristic gold and silver washes. Ties to the northwest, nevertheless, are shown in the continued attachment of animal protomes to bowl rims and the continued popularity of gray wares.

Tools and other items offer evidence of other specific connections. Leaf-shaped chisels (see, e.g., fig. 11 , no. 4) are found almost exclusively in the eastern Mediterranean, where faience beads (see, e.g., fig. 21, no. 5) also may originate. Such finds were likely imported via southeastern or eastern Aegean ports like

\footnotetext{
${ }^{95}$ Riehl 1999.

${ }^{96}$ Miller and Enneking 2014, 262. See Pliny (HN 22: 15153) for the negative effects of bitter vetch.
}

Panaztepe, where large amounts of glass and faience beads were recovered. From similar Aegean sources, discoid lead balance weights (see, e.g., fig. 23) reflect most clearly Kaymakçı's involvement in interregional trade networks. Similarly, while the bronze knife with the decorated handle (see fig. 22, no. 1) may be a local product, it belongs to a common Aegean and western Anatolian group of such items. Pins with melonshaped heads (see, e.g., fig. 20, nos. 4, 5), in contrast, appear to reflect links to central Anatolia.

This evidence might seem modest at first, but it should be remembered that Kaymakçı is an inland site, unexposed to the direct impact of Aegean maritime trade, and the evidence at hand was recovered in only three years of excavations, deriving from what appear to be relatively common settlement contexts. In contrast, the best parallels for materials from Kaymakçı were recovered from coastal cemeteries, including elite graves, at Panaztepe, Bakla Tepe, Beşik-Tepe, and elsewhere. Similarly, Beycesultan's interregional exchange connections are suggested primarily by a few singular imports and one group of rare finds from the so-called East Shrine. ${ }^{97}$

Evidence of subsistence economies from Kaymakçı reinforces its important geographic position and points to adaptive strategies specific to its local environmental conditions. Comparison of preliminary evidence from Kaymakçı with relevant LBA sites with published quantitative data suggests a subsistence strategy with a middle-ground combination of elements of Aegean and central Anatolian traits. Kaymakçı's ubiquity of legumes and relative absence of evidence for dung fuel is Aegean-like, while the ubiquity of cereals is Anatolian in character. ${ }^{98}$ The faunal assemblage also shows Aegean-leaning traditions in the high frequency of both pigs and fallow deer, a hallmark of Aegean-basin economies throughout pre- and protohistory, ${ }^{99}$ while numerous Mediterranean mollusks reflect extended regional networks. Local traditions are evident primarily in the fish assemblage. All in all, the material culture and subsistence practices of communities at Kaymakçı provide clear evidence of their involvement in various modes of local, Aegean, Anatolian, and eastern Mediterranean interactions.

\footnotetext{
${ }^{97}$ Mellaart and Murray 1995, 126-27, pl. 26.

${ }^{98}$ Riehl and Nesbitt 2003; Riehl et al. 2008; Marston 2012; Miller and Marston 2012.

${ }^{99}$ Fabiš 2003; Sykes 2014; Çakurlar and Atici 2017.
} 


\section{CONCLUSIONS AND CONTINUING RESEARCH}

The Kaymakçı Archaeological Project was founded with the aim of shedding light on the chronology, spatial organization, economies, and cultural orientations of the site and its ancient communities. After three years of excavation, the project has made strides toward this goal. The citadel can now be shown to have developed from the beginning of the second millennium through the 13th century B.C.E. Internal phasing based on ceramic analyses now separates at least three major phases-MBA, LB 1, and LB 2-as well as a still unclear slightly later phase. The organization of the citadel is becoming clearer spatially, even if new evidence will modify current understanding. Documentation of subsistence economies from botanical and faunal analyses highlights local traditions thatalong with analyses of ceramics and a variety of small finds - help situate Kaymakçı within its Aegean, Anatolian, and eastern Mediterranean milieu.

Excavations at Kaymakçı grew out of a project that began with a targeted survey of Iron Age tumuli in Lydia and continued with a 10 -year program of diachronic regional survey in the Marmara Lake basin (CLAS). Historical texts figured minimally, if at all, in these earlier research designs. Nearly 20 years on, however, it is hard to ignore their relevance. If understandings of Hittite geography are correct in situating the Seha River Land in the middle Gediz River valley, the demands of diplomacy at second-millennium B.C.E. Kaymakçı must have been significant: local communities sat at a critical node that had to balance local interests with those of Ahhiyawa and the Hittites. The connectivity of the region and site to east and west is now clear from the material remains and provides a material correlate for these diplomatic necessities, supporting the historical reconstruction.

As we begin to understand more about the phasing of specific contexts across the site, we expect future work to shed light on specific dimensions of political, ritual, and daily life at Kaymakçı, from the common community to its leadership. Such work should reflect not only on the cultural dynamics of the Aegean and central Anatolia but also on broader understandings of citadels, territories, and the importance of local community traditions.
Christopher H. Roosevelt

Department of Archaeology and History of Art Research Center for Anatolian Civilizations

Koç University

Rumelifeneri Yolu

Sarıer 34450 İstanbul

Turkey

chroosevelt@ku.edu.tr

Christina Luke

Department of Archaeology and History of Art

Koç University

Rumelifeneri Yolu

Sarlyer 34450 İstanbul

Turkey

christinaluke72@gmail.com

Sinan Ünlüsoy

School of Applied Sciences

Yaşar University, Üniversite Cad. 37-39

Bornova 35100 İzmir

Turkey

sinan.unlusoy@yasar.edu.tr

Canan Çakırlar

Groningen Institute of Archaeology

University of Groningen

Poststraat 6

NL-9712 ER Groningen

Netherlands

c.cakirlar@rug.nl

John M. Marston

Department of Archaeology

Boston University

675 Commonwealth Avenue

Boston, Massachusetts 02215

marston@bu.edu

Caitlin R. O'Grady

Institute of Archaeology

University College London

31-34 Gordon Square

WC1H 0PY London

United Kingdom

caitlin.r.ogrady@ucl.ac.uk

Peter Pavúk

Institute of Classical Archaeology

Charles University, Faculty of Arts

Celetná 20

CZ-110 00 Prague 1

Czech Republic

peter.pavuk@ff.cuni.cz 
Magda Pieniążek

Institute of Prehistory and Early History

University of Tübingen

Schloss Hohentübingen

72070 Tübingen

Germany

magda.pieniazek@ifu.uni-tuebingen.de

Jana Mokrišová

Department of History, Classics and Archaeology

Birkbeck, University of London

28 Russell Square

WC1B 5DQLondon

United Kingdom

jmokriso@umich.edu

Catherine B. Scott

Boston University

675 Commonwealth Avenue, Suite 347

Boston, Massachusetts 02215

scottcb@bu.edu

Nami Shin

Department of Archaeology and History of Art

Koç University

Rumelifeneri Yolu

Sariyer 34450 İstanbul

Turkey

namishin93@gmail.com

Francesca G. Slim

Groningen Institute of Archaeology

Universtity of Groningen

Poststraat 6

NL-9712 ER Groningen

Netherlands

f.g.slim@rug.nl

\section{Works Cited}

Andersson Strand, E. 2014. "From Spindle Whorls and Loom Weights to Fabrics in the Bronze Age Aegean and Eastern Mediterranean." In KOSMOS: Jewellery, Adornment and Textiles in the Aegean Bronze Age. Proceedings of the 13th International Aegean Conference, University of Copenhagen, Danish National Research Foundation's Centre for Textile Research, 21-26 April 2010, edited by R. Laffineur and M.L. Nosch, 206-14. Aegaeum 33. Leuven and Liège: Peeters. -2015. "The Basics of Textile Tools and Textile Technology: From Fibre to Fabric.” In Tools, Textiles and Contexts: Investigating Textile Production in the Aegean and Eastern Mediterranean Bronze Age, edited by E. Andersson Strand and M.L. Nosch, 39-60. Ancient Textiles 21. Oxford: Oxbow.

Aravantinos, V., and M.E. Alberti. 2006. "The Balance Weights from the Kadmeia, Thebes." In Weights in Context: Bronze Age Weighing Systems of Eastern Mediterranean. Chronology, Typology, Material and Archaeological Contexts, edited by M.E. Alberti, E. Ascalone, and L. Peyronel, 293314. Rome: Istituto Italiano di Numismatica.

Aykurt, A. 2010. "Late Bronze Age Pottery from Çeşme Bağlararası.” Olba 18:1-63.

. 2013. "An Updated Assessment on Western Anatolian Middle Bronze Age Chronology in Light of Excavations of the Izmir Region." Colloquium Anatolicum 12:37-77.

Basedow, M.2000. Beşik-Tepe: Das spätbronzezeitliche Gräberfeld. Studia Troica Monographien 1. Mainz: Zabern.

Bass, G. 1967. "Cape Gelidonya: A Bronze Age Shipwreck.” TAPS 37/8:1-177.

Baştürk, M.B. 2014. "The Northwestern Frontier of the Hittite Heartland: Hittite Presence in Eskişehir Region with the Help of Şarhöyük Material.” Paper read at the 20th Annual Meeting of the European Association of Archaeologists, 10-14 September 2014, Istanbul.

Bayne, N. 2000. The Grey Wares of North-West Anatolia in the Middle and Late Bronze Age and the Early Iron Age and Their Relation to the Early Greek Settlements. Bonn: Habelt. Ph.D. diss., University of Oxford, 1968.

Becker, C. 1986. Kastanas: Ausgrabungen in einem Siedlungshügel der Bronze und Eisenzeit Makedoniens 1975-1979. Die Tierknochenfunde. Berlin: Wissenschaftsverlag Volker Spiess.

Beckman, G., T.B. Bryce, and E. Cline. 2011. The Ahhiyawa Texts. Atlanta, Ga.: Society of Biblical Literature.

Blegen, C.W., J.L. Caskey, and M. Rawson. 1953. Troy: The Sixth Settlement. Princeton: Princeton University Press.

Blegen, C.W., C.G. Boulter, J.L. Caskey, and M. Rawson. 1958. Troy: Settlements VIIa, VIIb, and VIII. Princeton: Princeton University Press.

Boehmer, R.M. 1972. Die Kleinfunde von Boğazköy aus den Grabungskampagnen 1931-1939 und 1952-1969. Boğazköy-Hattusa 7. Berlin: G. Mann.

1979. Die Kleinfunde aus der Unterstadt von Boğazköy: Grabungskampagnen 1970-1978. Boğazköy-Hattusa 10. Berlin: G. Mann.

Bryce, T.R. 2005. The Kingdom of the Hittites. New ed. Oxford: Oxford University Press.

_. 2011. "The Late Bronze Age in the West and the Aegean." In The Oxford Handbook of Ancient Anatolia (10,000-323 BC), edited by S.R. Steadman and G. McMahon, 363-75. Oxford: Oxford University Press.

Buchholz, H.-G., and V. Karageorghis. 1971. Altägäis und Altkypros. Tübingen: Wasmuth.

Buchholz, H.-G., G. Jöhrens, and I. Maull. 1973. Jagd und Fischfang. ArchHom 2. Göttingen: Vandenhoeck and Ruprecht.

Çakırlar, C. 2009. "To the Shore and Back Again: Archaeomalacology of Troia." Studia Troica 18:59-86.

Çakırlar, C., and L. Atici. 2017. "Patterns of Animal Exploitation in Western Turkey: From Palaeolithic Molluscs to Byzantine Elephants." In The Oxford Handbook of Zooarchaeology, edited by U. Albarella, H. Russ, K. Vickers, and S. Viner-Daniels, 266-79. Oxford: Oxford University Press.

Çakırlar, C., L. Gourichon, S. Pilaar Birch, R. Berthon, M. Akar, and K.A. Yener. 2014. "Provisioning an Urban 
Center Under Foreign Occupation: Zooarchaeological Insights into the Hittite Presence in Late FourteenthCentury BCE Alalakh." Journal of Eastern Mediterranean Archaeology and Heritage Studies 2(4):259-76.

Catling, H. 1964. Cypriot Bronzework in the Mycenaean World. Oxford: Clarendon.

Çilingiroğlu, A., Z. Derin, E. Abay, H. Sağlamtimur, and İ. Kayan. 2004. Ulucak Höyük: Excavations Conducted Between 1995 and 2002. Ancient Near Eastern Studies Suppl. 15. Paris: Peeters.

Çınardalı-Karaaslan, N. 2012. "The East Mediterranean Late Bronze Age Glass Trade Within the Context of the Panaztepe Finds." OJA 31(2):121-41.

Çınaroğlu, A., and D. Çelik. 2013. "Alaca Höyük.” In The Hittites: An Anatolian Empire, edited by M. Doğan-Alparslan and M. Alparslan, 196-205. Anadolu uygarlıkları serisi 3. Istanbul: Yapı Kredi Yayınları.

d’Alpoim Guedes, J., and R.N. Spengler. 2014. "Sampling Strategies in Paleoethnobotanical Analysis." In Method and Theory in Paleoethnobotany, edited by J.M. Marston, J. d'Alpoim Guedes, and C. Warinner, 77-94. Boulder: University Press of Colorado.

Dandoy, J.R. 2006. "Astragali Through Time.” In Integrating Zooarchaeology, edited by M. Maltby, 131-37. Oxford: Oxford University Press.

Dedeoğlu, F., and E. Abay. 2014. "Beycesultan Höyük Excavation Project: New Archaeological Evidence from Late Bronze Age Layers." Arkeoloji Dergisi 19:1-39.

Deshayes, J. 1960. Les outils de bronze, de l'Indus au Danube (IV. au II. millénaire). Paris: Geuthner.

Ducos, P. 1965. “La faune de Beycesultan.” In Beycesultan II: Middle Bronze Architecture and Pottery, edited by S. Lloyd and J. Mellaart, 145-54. Occasional Publications 8. Ankara: British Institute of Archaeology at Ankara.

Easton, D.F., J.D. Hawkins, A.G. Sherratt, and E.S. Sherratt. 2002. “Troy in Recent Perspective." AnatSt 52:75-109.

Erkanal, A., and A. Aykurt. 2017. "Thoughts on the Anthropomorphic Pottery Vessel Found in Liman Tepe." In Overturning Certainties in Near Eastern Archaeology: A Festschrift in Honor of K. Aslihan Yener, edited by Ç. Maner, M.T. Horowitz, and A.S. Gilbert, 171-79. Leiden: Brill.

Erkanal, H. 2008. “Geç Tunç Çağı'nda Liman Tepe.” In Batı Anadolu ve Doğu Akdeniz Geç Tunç Çağı Kültürleri Üzerine Yeni Araştırmalar, edited by A. Erkanal-Öktü, S. Günel, and U. Deniz, 91-100. Ankara: Hacettepe Üniversitesi Yayınları.

Erkanal, H., and V. Şahoğlu. 2012. “Liman Tepe (1992- ).” In DTCF Arkeoloji Bölümü Tarihçesi ve Kazıları (1936-2011), edited by O. Bingöl, A. Öztan, and H. Taşkıran, 219-30. Ankara: Ankara Üniversitesi Basımevi.

Erkanal, H., A. Aykurt, K. Büyükulusoy, I. Tuğcu, R. Tuncel, and V. Şahoğlu. 2016. "Liman Tepe 2014 yılı kara ve sualtı kazıları.” Kazı Sonuçları Toplantısı 37(1):323-40.

Erkanal-Öktü, A. 2006. "Panaztepe'de Bulunan Kurşun Külçenin Ağırlığın Madencilikte Yerive Önemi.” Hacettepe Üniversitesi Edebiyat Fakültesi Dergisi 23(2):1-20.

Ervynck, A., A. Lentacker, G. Müldner, M. Richards, and K.M. Dobney. 2007. "An Investigation into the Transition from Forest Dwelling Pigs to Farm Animals in Medieval
Flanders, Belgium." In Pigs and Humans: 10,000 Years of Interaction, edited by U. Albarella, K.M. Dobney, A. Ervynvk, and P. Rowley-Conwy, 171-93. Oxford: Oxford University Press.

Fabiš, M. 2003. “Troia and Fallow Deer." In Troia and the Troad: Scientific Approaches, edited by G.A. Wagner, E. Pernicka, and H.-P. Uerpmann, 263-76. Berlin: Springer-Verlag.

Fairbairn, A., and S. Omura. 2005. "Archaeological Identification and Significance of ÉSAG (Agricultural Storage Pits) at Kaman-Kalehöyük, Central Anatolia." AnatSt 55:15-23.

French, D. 1969. "Prehistoric Sites in Northwest Anatolia II: The Balıkesir and Akhisar/Manisa Areas.” AnatSt 19:41-98.

Girella, L., and P. Pavúk. 2015. "Minoanisation, Acculturation, Hybridisation: The Evidence of the Minoan Presence in Northeastern Aegean Between Middle and Late Bronze Age." In NOSTOI: Indigenous Culture, Migration and Integration in the Aegean Islands and Western Anatolia During the Late Bronze and Early Iron Age, edited by N.C. Stampolidis, Ç. Maner, and K. Kopanias, 387-420. Istanbul: Koç University Press.

. 2016. "The Nature of Minoan and Mycenaean Involvement in the North-Eastern Aegean." In Beyond Thalassocracies: Understanding Processes of Minoanisation and Mycenaeanisation in the Aegean, edited by E. Gorogianni, P. Pavúk, and L. Girella, 15-42. Oxford: Oxbow.

Goldman, H. 1956. Excavations at Gözlü Kule, Tarsus. Vol. 2, From the Neolithic Through the Bronze Age. Princeton: Princeton University Press.

Grant, A. 1982. "The Use of Tooth Wear as a Guide to the Domestic Ungulates." In Ageing and Sexing Animal Bones from Archaeological Sites, edited by B. Wilson, C. Grigson, and S. Payne, 91-108. BAR-BS 109. Oxford: Oxford University Press.

Greaves, A.M. 2013. "Divine Things: The Ivories from the Artemision." In Luwian Identities: Culture, Language and Religion Between Anatolia and the Aegean, edited by A. Mouton, I. Rutherford, and I. Yakubovich, 509-41. Leiden: Brill.

Günel, S. 1999. Panaztepe II: Die Keramik von Panaztepe und ihre Bedeutung für Westkleinasien und die Ägäis im 2. Jahrtausend. Ankara: Türk Tarih Kurumu Basımevi.

_. 2008. "Çine-Tepecik kazıları ve bölge arkeolojisine katkıları.” In Batı Anadolu ve Doğu Akdeniz Geç Tunç Çağı Kültürleri Üzerine Yeni Araştırmalar, edited by A. ErkanalÖktü, S. Günel, and U. Deniz, 129-39. Ankara: Hacettepe Üniversitesi Yayınları.

2010. "Mycenaean Cultural Impact on the Çine (Marsyas) Plain, Southwest Anatolia: The Evidence from Çine-Tepecik." AnatSt 60:25-49.

Gunter, A.C. 1991. The Gordion Excavations Final Reports. Vol. 3, The Bronze Age. Philadelphia: University Museum.

Hänsel, A. 2014. "Die Metallfunde aus den bronzezeitlichen Siedlungsschichten.” In Heinrich Schliemanns Sammlung Trojanischer Altertümer: Neuvorlage. Vol. 2, Untersuchungen $z u$ den Schatzfunden, den Silber- und Bronzeartefakten, der Gusstechnik, den Gefäßmarken und den Bleigewichten, edited by M. Wemhoff, D. Hertel, and A. Hänsel, 129-204. 
Berlin: Staatliche Museen zu Berlin.

Hawkins, J.D. 1998. “Tarkasnawa, King of Mira: 'Tarkondemos,' Boğazköy Sealings and Karabel.” AnatSt 48:1-31.

Hughes-Brock, H. 1999. "Mycenaean Beads: Gender and Social Contexts.” OJA 18(3):277-96.

Ingram, R. 2005. "Faience and Glass Beads from the Late Bronze Age Shipwreck at Uluburun.” M.A. thesis, Texas A\&M University.

Joukowsky, M.S. 1986. Prehistoric Aphrodisias: An Account of the Excavations and Artifact Studies. Providence, R.I.: Brown University.

Kardulias, N., and C. Runnels. 1995. "The Lithic Artifacts: Flaked Stone and Other Nonflaked Lithics.” In Artifact and Assemblage: The Finds from a Regional Survey of the Southern Argolid, Greece. Vol. 1, edited by C.N. Runnels, D.J. Pullen, and S.H. Langdon, 74-139. Stanford, Calif.: Stanford University Press.

Kelder, J. 2009. The Kingdom of Mycenae: A Great Kingdom in the Late Bronze Age Aegean. Amsterdam: Free University.

Kessler, T.P. 2015. "A Royal Gift? Bulk Grain Storage in Protopalatial and Neopalatial Crete." SMEA N.S. 1:137-70.

Korfmann, M.O, ed. 2006. Troia: Archäologie eines Siedlungshügels und seiner Landschaft. Mainz: von Zabern.

Lassen, A.W. 2015. "Weaving with Crescent Shaped Loom Weights: An Investigation of a Special Kind of Loom Weight." In Tools, Textiles and Contexts: Investigating Textile Production in the Aegean and Eastern Mediterranean Bronze Age, edited by E. Andersson Strand and M.L. Nosch 2015, 127-37. Ancient Textiles 21. Oxford: Oxbow.

Lehner, J.W. 2011. "A Preliminary Report on the Microstructure and Microanalysis of Metal from Boğazköy.” In Die Ausgrabungen in Boğazköy-Hattuša 2010, edited by A. Schachner, 57-64. AA 2011. Berlin: Deutsches Archäologisches Institut.

-2015. "Cooperation, the Craft Economy, Metal Technology during the Bronze and Iron Ages in Central Anatolia.” Ph.D. diss., University of California at Los Angeles.

Lemoine, X., M.A. Zeder, K.J. Bishop, and S.J. Rufolo. 2014. "A New System for Computing Dentition-Based Age Profiles in Sus scrofa." JAS 47:179-93.

Lloyd, S., and J. Mellaart. 1965. Beycesultan. Vol. 2, Middle Bronze Age Architecture and Pottery. London: British Institute of Archaeology at Ankara.

Luke, C., and C.H. Roosevelt. 2009. "The Central Lydia Archaeological Survey: Documenting the Prehistoric Through Iron Age Periods." In Tree-Rings, Kings, and Old World Archaeology and Environment: Papers Presented in Honor of Peter Ian Kuniholm, edited by S.W. Manning and M.J. Bruce, 199-218. Oxford: Oxbow.

_2016. "Memory and Meaning in Bin Tepe, the Lydian Cemetery of a 'Thousand Mounds." In Tumulus as Sema: Proceedings of an International Conference on Space, Politics, Culture, and Religion in the First Millennium BC, edited by O. Henry and U. Kelp, 407-28. TOPOI Excellence Cluster Series 27. Berlin: De Gruyter.

_.2017. "Cup-Marks and Citadels: Evidence for Libation in the Second-Millennium BCE Marmara Lake Basin, Western Anatolia." BASOR 378:1-23.

Luke, C., C.H. Roosevelt, P. Cobb, and Ç. Çilingiroğlu. 2015.
"Composing Communities: Chalcolithic Through Iron Age Survey Ceramics in the Marmara Lake Basin, Western Turkey." JFA 40(4):428-49.

Maner, Ç. 2014. "Preliminary Report on the First Season of the Konya-Ereğli (KEYAR) Survey 2013.” Anatolia Antiqua 22:243-60.

2017. "A Metal Workshop? Multi-Hollow Anvils at Taştepe Obası in Southeastern Konya." In Overturning Certainties in Near Eastern Archaeology: A Festschrift in Honor of K. Aslihan Yener, edited by Ç. Maner, M.T. Horowitz, and A.S. Gilbert, 436-52. Leiden: Brill.

Mangaloğlu-Votruba, S. 2011. "Liman Tepe'de Geç Hellas IIIC dönemi." Anadolu/Anatolia 37:43-73.

. 2015. "Liman Tepe During the Late Bronze Age." In NOSTOI: Indigenous Culture, Migration and Integration in the Aegean Islands and Western Anatolia During the Late Bronze and Early Iron Age, edited by N.C. Stampolidis, Ç. Maner, and K. Kopanias, 647-68. Istanbul: Koç University Press.

Marston, J.M. 2012. "Agricultural Strategies and Political Economy in Ancient Anatolia." AJA 116(3):377-403.

- 2014. "Ratios and Simple Statistics in Paleoethnobotanical Analysis: Data Exploration and Hypothesis Testing." In Method and Theory in Paleoethnobotany, edited by J.M. Marston, J. d'Alpoim Guedes, and C. Warinner, 16379. Boulder: University Press of Colorado. 2017. Agricultural Sustainability and Environmental Change at Ancient Gordion. Philadelphia: University of Pennsylvania Museum.

Mellaart, J., and A. Murray. 1995. Beycesultan. Vol. 3, pt. 2, Late Bronze Age and Phrygian Pottery and Middle and Late Bronze Age Small Objects. London: British Institute of Archaeology at Ankara.

Mellink, M.J. 1956. A Hittite Cemetery at Gordion. Philadelphia: University of Pennsylvania Museum.

Meriç, R. 2003. "Excavations at Bademgediği Tepe (Puranda) 1999-2002: A Preliminary Report." IstMitt 53:79-98. .2007. "Ein Vorbericht über eine spätbronzezeitliche befestigte Höhensiedlung bei Metropolis in Ionien: Die Arzawa-Stadt Puranda?” In Frühes Ionien: Eine Bestandsaufnahme. Panionion-Symposion Güzalçaml 26. September-1. Oktober 1999, edited by J. Cobet, V. von Graeve, W.-D. Niemeier, and K. Zimmermann, 27-36. Milesische Forschungen 5. Mainz: von Zabern.

Meriç, R., and P.A. Mountjoy. 2002. "Mycenaean Pottery from Bademgediği Tepe (Puranda) Ionia: A Preliminary Report.” IstMitt 52:79-98.

Meriç, R., and A.K.Öz. 2015. "Bademgediği Tepe (Puranda) Near Metropolis.” In NOSTOI: Indigenous Culture, Migration and Integration in the Aegean Islands and Western Anatolia During the Late Bronze and Early Iron Age, edited by N.C. Stampolidis, Ç. Maner, and K. Kopanias, 609-26. Istanbul: Koç University Press.

Michailidou, A. 1990. "The Lead Weights from Akrotiri: The Archaeological Record." In Thera and the Aegean World. Vol. 3, pt. 1, Archaeology, edited by D.A. Hardy, C.G. Doumas, J.A. Sakellarakis and P.M. Warren, 407-19. London: Thera Foundation.

Miller, N.F. 1984. "The Use of Dung as Fuel: An Ethno- 
graphic Model and an Archaeological Example." Paléorient 10(2):71-9.

1997. "Farming and Herding Along the Euphrates: Environmental Constraint and Cultural Choice (Fourth to Second Millennia B.C.)." MASCAP 14:123-32.

2010. Botanical Aspects of Environment and Economy at Gordion, Turkey. Philadelphia: University of Pennsylvania Museum.

Miller, N.F., and D. Enneking. 2014. "Bitter Vetch (Vicia ervilia): Ancient Medicinal Crop and Farmers' Favorite for Feeding Livestock." In New Lives for Ancient and Extinct Crops, edited by P.E. Minnis, 254-68. Tuscon: University of Arizona Press.

Miller, N.F., and J.M. Marston. 2012. "Archaeological Fuel Remains as Indicators of Ancient West Asian Agropastoral and Land-Use Systems." Journal of Arid Environments 86:97-103.

Miller, N.F., M.A. Zeder, and S.R. Arter. 2009. "From Food and Fuel to Farms and Flocks: The Integration of Plant and Animal Remains in the Study of the Agropastoral Economy at Gordion, Turkey." CurrAnthr 50(6):915-24.

Mokrišová, J. 2016. "Minoanisation, Mycenaeanisation, and Mobility: A View from Southwest Anatolia.” In Beyond Thalassocracies: Understanding Processes of Minoanisation and Mycenaeanisation in the Aegean, edited by E. Gorogianni, P. Pavúk, and L. Girella, 43-57. Oxford and Philadelphia: Oxbow.

Moundrea-Agrafioti, A. 2003. "Mesolithic Fish Hooks from the Cave of Cyclope, Youra." In The Greek Mesolithic: Problems and Perspectives, edited by N. Galanidou and C. Perlès, 131-41. British School at Athens Studies 10. Athens: British School at Athens.

Mountjoy, P.A. 1998. “The East Aegean-West Anatolian Interface in the Late Bronze Age: Mycenaeans and the Kingdom of Ahhiyawa." AnatSt 48:33-67.

Müller-Karpe, A. 1994. Altanatolisches Metallhandwerk. OffaBücher 75. Neumünster: Wachholtz Verlag.

Niemeier, W.-D. 2005. "Minoans, Mycenaeans, Hittites and Ionians in Western Asia Minor: New Excavations at Bronze Age Miletus-Millawanda." In The Greeks in the East, edited by A. Villing, 1-36. London: British Museum.

Pavúk, P. 2014. Troia VI Früh und Mitte: Keramik, Stratigraphie, Chronologie. Studia Troica Monographien 3. Bonn: Habelt.

. 2015. "Between the Aegeans and the Hittites: Western Anatolia in the 2nd Millennium BC.” In NOSTOI: Indigenous Culture, Migration and Integration in the Aegean Islands and Western Anatolia During the Late Bronze and Early Iron Age, edited by N.C. Stampolidis, Ç. Maner, and K. Kopanias, 81-114. Istanbul: Koç University Press.

Pavúk, P., and M. Pieniążek. 2016. “Towards Understanding the Socio-Political Structures and Social Inequalities in Western Anatolia During the Late Bronze Age." In Rich and Poor: Competing for Resources in Prehistory. Tagungsband des 8. Mitteldeutschen Archäologentages in Halle, 22.-24. November 2015, edited by H. Meller, H.P. Hahn, R. Jung, and R. Risch, 531-51. Tagungen des Landesmuseums für Vorgeschichte Halle 14/I. Halle and Saale: Landesmuseum für Vorgeschichte.
Pavúk, P., M. Pieniążek, and S. Riehl. 2014. "Troy and the Troad in the Second Millennium: Changing Patterns in Landscape Use." In PHYSIS: L'environnement naturel et la relation homme-milieu dans le monde égéen protohistorique, edited by G. Touchais, R. Laffineur, and F. Rougemont, 111-20. Aegaeum 37. Leuven: Peeters.

Pearsall, D.M. 2015. Paleoethnobotany: A Handbook of Procedures. 3rd ed. Walnut Creek, Calif.: Left Coast Press.

Petruso, K. 1978. "Lead Weights from Akrotiri, Preliminary Observations." In Thera and the Aegean World I, edited by C. Dumas, 547-53. London: Thera and the Aegean World.

Pieniążek, M. 2012a. “Troianischer Schmuckim Kontext: Ein Vorbericht zu den Schmuckfunden des 2. Jahrtausends v. Chr." Studia Troica 19:205-18.

2012b. "Luxury and Prestige on the Edge of the Mediterranean World: Jewellery from Troia and the Northern Aegean in the 2nd Millennium B.C. and Its Context." In KOSMOS: Jewellery, Adornment and Textiles in the Aegean Bronze Age. Proceedings of the 13th International Aegean Conference, University of Copenhagen, Danish National Research Foundation's Centre for Textile Research, 21-26 April 2010, edited by R. Laffineur and M.L. Nosch, 501-8. Aegaeum 33. Leuven and Liège: Peeters.

. 2015. Dress and Body Ornaments as a Testimony to Cross-Cultural Influences in the Northern Area of the Aegean. In NOSTOI: Indigenous Culture, Migration and Integration in the Aegean Islands and Western Anatolia During the Late Bronze and Early Iron Age, edited by N.C. Stampolidis, Ç. Maner, and K. Kopanias, 871-88. Istanbul: Koç University Press.

_ 2016. "Zur Produktion von 'Luxus': Das frühbronzezeitliche Troia als Fallstudie zum prähistorischen Goldschmieden und Schmucksteinschleifen.” In Wirtschaft als Machtbasis: Beiträge zur Rekonstruktion vormoderner Wirtschaftssysteme in Anatolien, edited by K. Piesker, 131-52. Byzas 22. Istanbul: Yayınları.

Pieniążek, M., and C. Aslan. 2016. "Heroic Past, Memory and Ritual at Troy." In Metaphysis: Ritual, Myth and Symbolism in the Aegean Bronze Age. 15th International Aegean Conference Held at Vienna 2014, edited by E. Alram-Stern, F. Blakolmer, S. Deger-Jalkotzy, R. Laffineur and J. Weilhartner, 423-32. Aegaeum 39. Leuven: Peeters.

Privitera, S. 2014. "Long-Term Grain Storage and Political Economy in Bronze Age Crete: Contextualizing Ayia Triada's Silo Complexes." AJA 118(3):429-49.

Pulak, C. 1996. Analysis of the Weight Assemblages from the Late Bronze Age Shipwrecks at Uluburun and Cape Gelidonya, Turkey. Ph.D. diss., University of Texas, Austin.

Reese, D.S. 1984. “Topshell Rings in the Aegean Bronze Age." BSA 79:237-38.

Reitz, E.J., and E.S. Wing. 2008.Zooarchaeology. 2nd ed. Cambridge: Cambridge University Press.

Riehl, S. 1999. Bronze Age Environment and Economy in the Troad: The Archaeobotany of Kumtepe and Troy. Tübingen: Mo Vince Verlag.

-2014. "Significance of Prehistoric Weed Floras for the Reconstruction of Relations between Environment and Crop Husbandry Practices in the Near East." In Ancient Plants and People: Contemporary Trends in Archaeobotany, 
edited by M. Madella, C. Lancelotti, and M. Savard, 13552. Tucson: University of Arizona Press.

Riehl, S., and M. Nesbitt. 2003. "Crops and Cultivation in the Iron Age Near East: Change or Continuity?” In Identifying Changes: The Transition from Bronze to Iron Ages in Anatolia and Its Neighbouring Regions, edited by B. Fischer, H. Genz, É. Jean, and K. Köroğlu, 301-12. Istanbul: Türk Eskiçağ Bilimleri Enstitüsü Yayınları.

Riehl, S., R. Bryson, and K. Pustovoytov. 2008. "Changing Growing Conditions for Crops During the Near Eastern Bronze Age (3000-1200 BC): The Stable Carbon Isotope Evidence." JAS 35(4):1011-22.

Rigter, W., and Thumm-Doğrayan, D. 2014. "Ein hohlgeformter Stier aus Troia." Studia Troica 14:87-100.

Roosevelt, C.H. 2003. "Lydian and Persian Period Settlement in Lydia." Ph.D. diss., Cornell University.

Roosevelt, C.H., and C. Luke. 2017. "The Story of a Forgotten Kingdom? Survey Archaeology and the Historical Geography of Central Western Anatolia in the Second Millennium BC.” EJA 20(1):120-47.

Roosevelt, C.H., P. Cobb, E. Moss, B.R. Olson, and S. Ünlüsoy. 2015. "Excavation Is Đestruction Digitization: Advances in Archaeological Practice." JFA 40(3):325-46.

Şahoğlu, V., Ü.Ç. Böyükulusoy, Y.H. Erbil, H. Erkanal, and İ. Tuğcu. 2014. "2012 Yılı Çeşme-Bağlararası Kazıları.” Anadolu/Anatolia 40:179-94.

Sandars, N.K. 1955. "The Antiquity of the One-Edged Bronze Knife in the Aegean.” PPS 221:174-97.

Schaeffer, C.F.A. 1952. Enkomi-Alasia: Nouvelles missions en Chypre 1946-1950. Paris: Klincksieck.

Schalk, E. 2008. "Die Bronzenadeln in der Berliner Sammlung." In Heinrich Schliemanns Sammlung Trojanischer Altertümer-Neuvorlage. Vol. 1, Forschungsgeschichte, keramische Funde der Schichten VII bis IX, Nadeln, Gewichte und durchlochte Tongeräte, edited by M. Wemhoff, D. Hertel, and A. Hänsel, 183-226. Berlin: Staatliche Museen zu Berlin.

Schmidt, E. 1932. Alishar Hüyük: Seasons of 1928 and 1929. Chicago: University of Chicago Press.

Schmidt, H. 1902. Heinrich Schliemann's Sammlung trojanischer Altertümer. Berlin: Reimer.
Schwartz, G.M., H.H. Curvers, F.A. Gerritsen, J.A. MacCormack, N.F. Miller, and J.A. Weber. 2000. "Excavation and Survey in the Jabbul Plain, Western Syria: The Umm elMarra Project 1996-1997.” AJA 104(3):419-62.

Süel, A., and M. Süel. 2013. "Sapinuwa: Another Capital City of Hittite State." In The Hittites: An Anatolian Empire, edited by M. Doğan-Alparslan and M. Alparslan, 178-93. Anadolu uygarlıkları serisi 3. Istanbul: Yapı Kredi Yayınları.

Sykes, N.J., 2014. "Hunting and Hunting Landscapes." In Encyclopedia of Global Archaeology, 3592-611. Springer: New York.

Thumm-Doğrayan, D., P. Pavúk, and M. Pieniążek. Forthcoming. "Economy and Storage Strategies at Troy." In Country in the City: Forms and Functions of Agro-Pastoral Activities in Mediterranean Pre-Classical Cities, edited by D. Garcia, R. Orgeolet, M. Pomadère, and J. Zurbach. Oxford: Archaeopress.

Uerpmann, H.P. 2003. "Environmental Aspects of Economic Changes in Troia." In Troia and the Troad: Scientific Approaches, edited by G.A. Wagner, E. Pernicka, and H.P. Uerpmann, 251-62. Berlin: Springer Verlag.

Üstünkaya, M.C. 2015. "Investigating Climate Related Agricultural Stress Patterns at Bronze and Iron Age KamanKalehöyük: The Integration of Botanical Stable Carbon and Nitrogen Isotope Values, Grain Weight Values, and Seed Analysis." Ph.D. diss., University of Queensland.

von den Driesch, A., and N. Pöllath. 2004. Vor- und frühgeschichtliche Nutztierhaltung und Jagd auf Büyükkaya in Boğazköy-Hattusa, Zentralanatolien. Boğazköy-Berichte 7. Mainz: von Zabern.

von der Osten, H.H. 1937. Alishar Hüyük: Seasons of 19301932. Pt. 2. Chicago: University of Chicago Press.

Yalçın, Ü., C. Pulak, and R. Slotta. 2005. Das Schiff Uluburun: Welthandel vor 3000 Jahren. Katalog der Ausstellung des Deutschen Bergbau Museums Bochum 15.-16. Juli 2006. Bochum: Deutsches Bergbau Museum.

Zeder, M.A. 2006. "Reconciling Rates of Long Bone Fusion and Tooth Eruption in Sheep (Ovis) and Goat (Capra)." In Recent Advances in Ageing and Sexing Animal Bones, edited by D. Ruscillo, 87-118. Durham: Oxbow. 